\title{
FLORA OF PERU
}

PART I, NO. 2

\author{
BY \\ J. Francis Macbride \\ CURATOR, PERUVIAN BOTANY
}

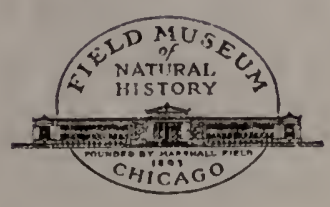

BOTANICAL SERIES

FIELD MUSEUM OF NATURAL HISTORY VOLUME XIII, PART I, NUMBER 2

E LIBRAPY OF THE AUGUST 17,1960

AUG 291960 
7

(1)

4

I

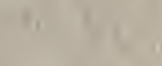

$x+2+2 x+1$

1)

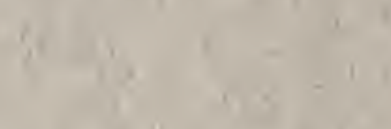

$$
\begin{aligned}
& \text { I } 19=9
\end{aligned}
$$

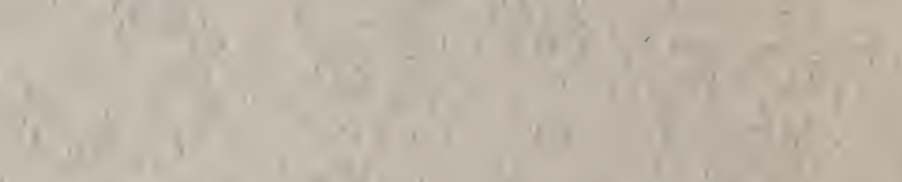

'th<smiles>CCC</smiles>

$-1+2$

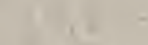

$\mathrm{pr}^{-1}$

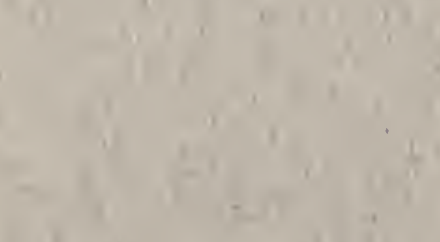

$1+1$<smiles>C=C(C)C1CCCCC1</smiles>

$+1$

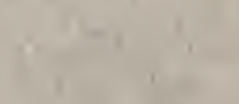






\title{
FLORA OF PERU PART I, NO. 2
}

\author{
BY \\ J. FRANCIS MACBRIDE \\ CURATOR, PERUVIAN BOTANY
}

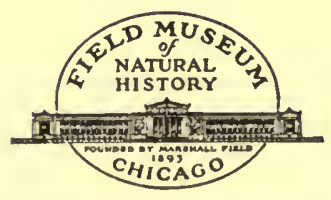

BOTANICAL SERIES

FIELD MUSEUM OF NATURAL HISTORY VOLUME XIII, PART I, NUMBER 2 AUGUST 17, 1960 
Library of Congress Catalog Card Number: 36-10426

PRINTED IN THE UNITED STATES OF AMERICA BY CHICAGO NATURAL HISTORY MUSEUM PRESS 


\section{FLORA OF PERU}

\section{J. Francis MACBRIDE}

\section{PAlMaE. Palm Family.}

Ligneous, smooth or more or less rudely spiny or prickly, acaulescent or caulescent, sometimes scandent or caudices low or tall, clustered or more often solitary, slender or columnar, nearly always strict, not rarely magnificent trees conveying the impression of great nobility, each crowned as it were with a beautifully proportioned cluster of several to many usually palmate or pinnate frond-like leaves, these again, especially among low or smaller species, variously divided or even entire, often few and gracefully ornamental. Petioles in greater or less degree sheath-like, spadix (inflorescence) commonly with 2several spathes, the lower much longer, the upper split in anthesis, coriaceous or ligneous. Not unlike Cyclanthaceae, but fruit rarely a syncarp; leaves at least tardily deciduous, the small (rarely about $1 \mathrm{~cm}$. long), soon often chaff-like flowers briefly open, single or ternate, the central ordinarily female, its perianth usually persisting. Ovary commonly 3-celled, usually 1 ovule developing. Fruit more or less drupiform, variously fleshy, even plum-like, not infrequently fibrous or (and) coriaceous, rarely papery, the seed frequently included in a mesocarp that is extremely indurated and covered with the often intricately branched raphe; the fruit within soft or even early liquid; endosperm finally hard or firm, ruminated or homogenous; embryo basal, lateral or apical, sometimes at an intermediate position.-Few families are so generally recognized as this one, but it is so diverse in all characters that it can be - and has been-(see most standard reference works) described in great detail, although this is not necessary here.

Notwithstanding the relatively few who have proposed and developed the taxonomy, there has been considerable disparity regarding generic relationships and even more concerning generic lines. By and large the former as presented in recent works has been generally accepted but the latter in many cases still often expresses disagreements. In equivocal genera my own desire would be to give preference to unique or at least apparently stable characters, and to restrict the use of recurring or variable ones to species or groups (sections) within the genus. 
In the case of the palms the contemporary who has advanced their study most intelligently is M. Burret, whose thoughtful work, cited on many of the following pages, is acknowledged with appreciation. The notable bibliographical contribution to the study of palms is that of my friend B. E. Dahlgren (Field Mus. Bot. 14:1-456. 1936). Compendiums like this lead without loss of time to all the literature available. In this family the citations to Weberbauer refer to the Spanish edition (El Mundo Veg. Andes Peru, 1945). The generic key, traditionally usable only by those whose vocation is the study of palms, has been devised with some sacrifice of precision for the benefit of those whose interest in them is a hobby; the natural but impractical division of the family, however, on character of fruit, has, regrettably, been retained, with the addition of one or two supplementary characteristics.

The usefulness of palms, especially in primitive societies, has been described in numerous articles and books. Now, however, many think of palms chiefly as a source of coconuts (Cocos nucifera L.) and dates (Phoenix dactylifera L.) or are entranced by their noble or graceful beauty.

Many contemporaries have been mentioned since the first number of Part I of Field Museum's Flora of Peru appeared; to this number I would add a single name, Aven Nelson, my student mentor, who enjoyed fame because his interest in others exceeded that in himself.

Leaves pinnate; male flowers in dense catkins; fruits capitately crowded, strongly tubercled.............. Phytelephas.

Leaves flabellate-palmate-parted; fruits never as above.

Fruits tessellate; petioles not ligulate, leaves subconcolor; male flowers (at least) amentaceous.

Spadix branches long; flowers seriately spiralled; seeds esulcate. 2. Mauritia.

Spadix branches short; flowers often distichous; seeds sulcate.

3. Lepidocaryum.

Fruits corky roughened or smooth; petioles ligulate; leaves silvery beneath.

Epicarp corky; leaves subbasally parted.....4. Chelyocarpus. Epicarp smooth; leaves biparted, each half incised.

5. Tessmanniophoenix.

Leaves various but never palmate, often pinnatifid, pinnate or furcate, rarely simple; fruits various. 
Endocarp (nut) without obvious pores, the carpels (usually 3) distinct or partly coalescent, in any case not finally an osseous shell; plants smooth or (and) with caudex root props; female petals sometimes imbricate.

Leaf divisions or leaf more or less expanded apically, cuneatebased; caudex root-supported.

Spadix branches simple; stamens 9-many; spathes often 3-many.

Spadix bisexual; leaf parts often much wider at apex.

9. Iriartea.

Spadix unisexual; leaf parts (Peru) oblanceolate.

10. Catoblastus.

Spadix often simple, axis thick, sexes separate; stamens 12-16; fruit villous...................11. Wettinia.

Leaves more or less pinnate, rarely entire, often bifid or segments oblique, sometimes ensiform-acuminate.

Caudices slender, low or tall.

Peduncle-spathes or bracts often 3-many; flowers rarely monoecious in diverse spadices, these finally simply scarred.

Flower groups long-seriate (always?). .13. Wendlandiella. Flower groups not or not clearly seriate (always?).

All spadices same sex on a plant...14. Chamaeodorea.

Spadices of each sex on a plant.......15. Morenia.

Peduncle-spathes 2 or 3 ; flowers monoecious in diverse spadices; plants arundinaceous.........16. Hyospathe.

Caudices stout or (and) spathes only 2.

Spathes 5; leaf segments rigid, ensiform; caudex robust, waxy; monoecious.............12. Ceroxylon. Spathes 2; characters otherwise than above.

Leaves unevenly pinnate or (and) flowers immersed.

Flowers sessile, male petals sublanceolate, female imbricate...............16. Hyospathe.

Flowers immersed, calyx segments imbricate as connate female petals; leaves various as in Chamaeodorea.

Anther cells united, sagittate-cordate, filaments cupulately united..........6. Calyptronoma. 
Anther cells free, lax from cupulate tube.

7. Geonoma.

Anther cells free but porrect, filaments usually connate................. Taenianthera.

Leaves evenly pinnate, segments acuminate, divaricate; female petals imbricate.

Flowers sessile, spadix branches pendulous, sheath fusiform, split; male sepals valvate.

17. Jessenia, 18. Oenocarpus.

Flowers more or less immersed, spadix elongate, erect, sheath cylindric, entire; male sepals imbricate.

19. Euterpe.

Endocarp (nut) with usually 3 obvious pores, the 3 or more carpels coalescent; typified by the pores and osseous shell of the cultivated coconut, but fruit (as Aiphanes) may be drupe-like and endocarp may be thin (as Desmoncus).

Plants aculeate (more or less, rarely not, Bactris); sepals as petals valvate or connate (always?).

Upper pinnae reduced, spiniform; endocarp thin or firm; plants dependent, sprawling, clinging.......28. Desmoncus.

Upper pinnae developed normally to rachis tip; endocarp osseous; plants independent (erect unless at base).

Pinnae erose; male flowers usually immersed, congested, female corollas urceolate; spathes cymbiform; pericarp often dry, rough, even aculeate..26. Astrocaryum.

Pinnae same, male flowers sessile, often scattered; petals fleshy, all basally connate, usually valvate; pericarp subfleshy..................25. Aiphanes.

Pinnae at least terminal, attenuate; flowers sessile, variously disposed; pericarp more or less fleshy.

27. Bactris.

Plants smooth, more or less fleshy (lower pinnae rarely spiniform); perianth parts convolute-imbricate; leaf segments attenuate apically; fruit 1-6-seeded.

Stamens 6; petals subcoriaceous; fruit 1-3-seeded.

Petals minute; stamens subexserted or exserted; seeds 1.

24. Maximilliana.

Petals elongate, thick; stamens included; seeds 1-3.

22. Syagrus, 23. Scheelea. 
Stamens 6-many, anthers direct, included; petals lanceolate; seeds $2-6 \ldots \ldots \ldots \ldots \ldots \ldots \ldots \ldots . \ldots \ldots$. Attalea.

Stamens 12-24, anthers not direct, at least sinuous; petals ovate; seeds $2-6 \ldots \ldots \ldots \ldots \ldots \ldots \ldots \ldots \ldots$. Orbignya.

\section{PHYTELEPHAS R. \& P.}

Elephantusia Willd. Sp. Pl. 4, pt. 2: 175b. 1805. Yarina Cook, Journ. Wash. Acad. Sci. 17: 223. 1927. Polandra Cook, l.c. 228.

Reference: Cook, Journ. Wash. Acad. Sci. 17: 218-230. 1927.

Smooth, with erect or inclined and rooting, moderately to very stout trunks, the species in Peru low but with many or few tall (elongate) terminal pinnate leaves. Flowers large, dioecious, the basal (Peru) spadices and peduncles squamate, the male rather amentaceous, more or less pendulous, simple, more or less scurvy, elongate, the female capitate, compact, erect. Stamens many, clustered, anthers basifixed. Sepals 3, imbricate, as the 5-10 rather fleshy narrow acuminate petals. Staminodia many; ovary 4-9-sulcate, -celled, each cell with a single erect ovule, style terminal, stigma long-filiform. Fruits more or less pressed together forming a large or small syncarp, 1-celled, more or less succulent or lignescent, shortly broadly and acutely tubercled, the hard nutlets loosely fibrous, embryo sunken near hilum in plane ivory-like albumen.-The several segregate genera proposed by Cook have doubtful merit unless the diagnostic characters are accepted also in several other genera as defining separate groups. Many illustrations are available, but some at least scarcely refer to the two original species unless, as possible, the several others proposed, as Panama species, are the same or merely variants; consequently, only one or two drawings and a photograph are listed which represent at least the genus as it occurs in Peru. It stands apart in the family on account of the 4-9 united carpels, usually maturing several large long seeds.

Vegetable ivory is supplied by the fruits of this extraordinary palm, described well by the authors: Early the fruits are filled with a liquid as clear as water, in place of which it is sometimes used; after some days it turns milky and acid; later it changes into a sweet and pleasant emulsion and successively acquires greater consistency, solidity and weight until it becomes as hard as ivory; small objects, as buttons, may be turned in a lathe with more ease than ivory ones because it is neither splintery nor fibrous; furthermore, it remains white for many years. The leaves are commonly used for thatch. 
Besides the following, two or three species have been illustrated under other names without diagnosis.

Trunks as petioles none or short, stout; leaf segments approximate, opposite; fruit lignescent................. . macrocarpa.

Trunks as petioles more or less developed; leaf segments distant; fruit succulent........................ microcarpa.

\section{Phytelephas macrocarpa R. \& P. Syst. Veg. 301. 1798; 224.}

Trunk none or short and inclined; leaves equally pinnate, crowded, the rachis basally incrassate, sessile or nearly, segments about 100 pairs, mostly exactly opposite, basally reduplicate, linear-lanceolate, attenuate, the medial about $12 \mathrm{dm}$. long, $3.5 \mathrm{~cm}$. wide, the upper scarcely $8 \mathrm{dm}$. long; spadices axillary, male ascending, fleshy, spiciform, $10 \mathrm{dm}$. long or slightly longer, peduncle compressed, $2.5 \mathrm{dm}$. long, $1.5 \mathrm{~cm}$. thick, rachis nearly $8 \mathrm{dm}$. long, flowers sessile or subsessile, a cluster of many (150-280) stamens, filaments $7 \mathrm{~mm}$. long, anthers $4 \mathrm{~mm}$. long; spathes 2 , glabrate, the outer nearly $2 \mathrm{dm}$. long, the inner $1 \mathrm{dm}$. long, $5 \mathrm{~cm}$. across, linear-fusiform; peduncle and female spadix longer than male, the $12-20$ sessile clusters apically compressed in an apical oval receptacle; bracteolate ovaries many, coalescent, the few central ones fertile, style filiform, $5 \mathrm{~cm}$. long, stigmas 5 or $6,5 \mathrm{~cm}$. long; fruits in a globose mass (12-20) $2.5 \mathrm{dm}$. in diameter or longer, the mature by mutual pressure 4-6-angulateobpyramidate, apically muricate-tubercled, nutlets about $4 \mathrm{~cm}$. long, $2.5 \mathrm{~cm}$. broad, perianth fragile.-After Spruce, Journ. Linn. Soc. 11: 179. 1871, who described P. aequitorialis of Ecuador (Polandra Cook), trunk 5 meters or taller, leaves unequally pinnate, the segments aggregate, male capitula stalked or racemed on a pendulous spadix, each capitulum with a thousand or more stamens; may occur in adjacent Peru. Illustrated, Huber, Bull. Herb. Boiss. sér. 2, 6: pl. 11.

San Martín: Vitoc, (Ruiz \& Pavón). Tarapoto, (Spruce).-Huánuco: Chanchamayo, San Antonio de Playa, Macora, (Ruiz \& Pavón, type).--Loreto: Headwaters of Río Purus, (Chandless).-Río Acre: Toward origin, (Huber). "Pulu-puntu," "polo-ponto," "humiro."

Phy telephas microcarpa R. \& P. Syst. Veg. 302.1798. Yarina microcarpa (R. \& P.) Cook, Journ. Wash. Acad. Sci. 17: 223. 1927.

Fruiting sometimes with no stem at all, finally with inclined stem about $1 \mathrm{dm}$. thick, spirally areolate with the deep leaf-scars; petiole elongate, leaf segments equal (Spruce), slender, with 6-7 leaves, segments widely spaced, spreading, retrorse below, the lower much 
shorter, the petioles perhaps 3-6 dm. long (Cook).-The thick muricated rind of the fruit is reddish within, tough but may be eaten, flavor of melon or milky cheese; the albumen is drunk while still watery, eaten when fleshy, suggesting immature coconut, when mature ivory-like (Spruce). Otherwise apparently unknown. Illustrated, Pflanzenfam. 2, Abt. 3: 87 (flowers, fruits, at least in part); 88 (plant).

Huánuco: Pozuzo, Pampa Hermosa, (Ruiz \& Pavón, type).Loreto: Near mouth of Río Napo, (Spruce). Río Pastaza, (Spruce). Ecuador? "Yarina," "rullipunta," "anon de palma."

\section{MAURITIA L. f.}

Mauritiella Burret, Notizbl. Bot. Gart. Berlin 12: 609-611. 1935.

Reference: Burret, 1.c. 605-609. 1935.

Trees, the columnar trunk with a dense crown of deeply or flabellately divided semicircular leaves, the often large inflorescences pendent from their axils. Branches of spadix simple, at least male amentaceous, sessile, exserted from the spathe, the flowers densely spiralled, the internodes vaginate. Calyx 3-lobed, corolla 3-fid, male approximate, female few on short branches, staminodia connate with petals. Ovary (absent in male flowers) 3-celled, stigma sessile, ovule basal, erect. Fruit ellipsoid or globose, 1-seeded, tessellate with retrorse lustrous scales (and leaves).--Small prickly-stemmed species have been separated as a distinct genus by Burret, also by Hawkes; cf. $M$. peruviana Becc. The question of the correct name for those who wish to use the segregate genus is arguable, and perhaps conservation could here be useful. The segregate has both sexes in aments.

Stems, leaves smooth, these concolor.

Rachis strongly flexuose; fruit depressed............. flexuosa.

Rachis slightly angled; fruit acute.............. vinifera. Stems, leaves prickly, these pale-scaly beneath.......M. peruviana.

\section{Mauritia flexuosa L. f. Suppl. 454. 1781; 290.}

Smooth, the trunk to $7 \mathrm{dm}$. thick, 50 meters tall, medially slightly tumid, the leaves deeply radiately flabellate; stout petioles subterete, canaliculate above, subequaling the blades, these 8-12 dm. long, segments 2-4 cm. wide; spadices 2-3 meters long, shortly peduncled, the male branches flexuose, elongate-cylindric, about 30, many 1 meter long, flexuose between the floriferous branchlets, these $5 \mathrm{~cm}$. long; 
bracts scabrous-ciliate; flowers densely fuscous-velutinous or flavescent, calyx (male) turbinate, corolla 3-parted from stipiform base, segments lanceolate, acute, petals much smaller, stamens 6 , anthers erect, oblique-cordate; calyx (female) urceolate, shortly lobed, corolla 3-lobed; fruit $4 \mathrm{~cm}$. high and thick, depressed-globose.-After Drude; Ule found it on the Río Juruá Mirim nearly at the Peruvian boundary, and Weberbauer saw it frequently cultivated but also in a natural state. Possibly occurring is the similar $M$. minor Burret, Notizbl. Bot. Gart. Berlin 11: 1. 1930, from adjacent Colombia, smaller in all its parts. Illustrated, Pflanzenfam. 2, Abt. 3: 42, fig. 33 (habit); Drude, Mart. Fl. Bras. 3, pt. 2: pls. 62, fig. 2 (fruit), 63, (habit), 65, fig. 1, 67, fig. 2; Weberbauer, 584, pl. 33.

San Martín: Moyobamba, (Weberbauer).-Loreto: Tessmann, fide Dahlgren. To the Guianas. "Aguaje," "achual," "buritisol" (Ule, Brazil).

Mauritia peruviana Becc. Ann. Bot. Gard. Calcutta 12, pt. 2: 225. 1918. Mauritiella peruviana (Becc.) Burret, Notizbl. Bot. Gart. Berlin 12: 609. 1935. Lepidococcus peruvianus (Becc.) A. D. Hawkes, Arquiv. Bot. São Paulo 2: 2. 1952.

Type about 20 meters tall, the leaves deeply parted into many narrow long-acuminate segments, white waxy puberulent above, minutely and sparsely brown squamate beneath, the scales hair-like, the margins and midrib smooth; largest segments $7.5-8 \mathrm{dm}$. long, $2.5 \mathrm{~cm}$. wide; male spadix 1.5 meter long, spathes of the spike bearing branches broadly infundibuliform, 6-7 cm. long, about as wide at opening; larger spikes $1 \mathrm{~cm}$. long, the 18-20 male flowers (female unknown) oblong, obtuse, not distinctly biseriate, $6 \mathrm{~mm}$. long, $3 \mathrm{~mm}$. broad; stamens 6.--It seems rather closely related to $M$. armata Mart. For the basic purpose of this work-identification-the traditional designation of this little palm, with apparently solitary trunk (author), and its allies as a subgroup of Mauritia seems to be the useful classification. Francia Chisaki kindly copied for me Beccardi's description from the University of California library at Berkeley.

San Martín: In woody savannah, Moyobamba to Rioja, (Weberbauer 471\%, type).

Mauritia vinifera Mart. Hist. Nat. Palm. 2: 42, pls. 38, 39. $1824 ; 291$.

Resembles $M$. flexuosa; cylindric caudex early annulate; male spadix branches about half as long, less bent or angled between the stouter 
branchlets; bracts and flowers finally glabrescent; fruit ovoid-ellipsoid, acute, $5 \mathrm{~cm}$. long, 3.5-4 cm. thick.-May extend into southeastern Peru from Bolivia; listed by Dahlgren 1.c. 418. Illustrated, Drude in Mart. Fl. Bras. 3, pt. 2: pls. 62, 6\%.

Peru (see above). Bolivia; Brazil.

\section{LEPIDOGARYUM Mart.}

Slender smooth erect or flexuose stemmed with flabelliform palmately parted leaves, slender petioles, elongate inflated convolute sheaths. Floriferous branches of the spadices short, often distichous. Ovule horizontal.-Allied to Mauritia, to which it has been referred.

Male spadix branches many; flowers of both sexes shorter than $8 \mathrm{~mm}$.

L. tenue.

Male spadix branches 6 or 7 ; flowers at least $8 \mathrm{~mm}$. long.

L. Tessmannii.

Lepidocaryum tenue Mart. Hist. Nat. Palm. 2: 51, pl. 7. 1823. L. enneaphyllum Barb. Rodr. Enum. Palm. Nov. 19. 1875, fide Trail and Drude.

Caudex slender, to several meters tall; fronds $12-15$ or more, to 2 meters long, glabrous except ciliate-spinulose margins of pinnae and midnerves, green, lustrous; petioles basally vaginate-lanceolate, anteriorly compressed-terete, to three times longer than the flabellatepinnatifid blade, this medially biparted even to base, mostly with 4 . lanceolate acute pinnae parted to base (pinnae constantly 9 , the 2 ultimate binate, fide Rodriguez) or joined below, medially at least $7.5 \mathrm{~cm}$. wide, primary nerves acutely prominent above; male spadices not seen, the hermaphrodite to 1 meter long, peduncles subcompressed, spathes membranous, linear-lanceolate, obliquely truncate, glabrate, the rachis extension stout, glabrous or evanescently and finely tomentose, the 3-4 amentiferous branches $2.5 \mathrm{~cm}$. distant, exserted from a tomentose spathe; spathes of branches 15-20, cyathiform, base of each black-annulate; scales suborbicular, subamplexicaul with rachis, lustrous; flowers solitary in each little spathe, pale rose color, the calyx campanulate, 3-denticulate, the corolla two times longer, petals erect, lanceolate, acute; stamens 6 ; anthers linear-oblong, 9 , ovate (in male flower observed in hermaphrodite spadix); ovary ovoid, attenuate at both ends, minutely squamulate; stigma pyramidally connate, twice as long as ovary; fruit oblong-cylindric, tessellatesquamate, lower margin of scales membranous, obscurely ciliolate, 
apically black-fuscous; inner seed coat soft, very thin, reddish-gray with fuscous veins and adhering to scales; seed ellipsoid, testa castaneous, lustrous; raphe developed entire length; albumen solid, osseous, embryo softer, conical, lateral.- - Fruit size of a walnut (Martius), presumably typical in character for the genus. Francia Chisaki generously copied for me the detailed original description, here much reduced; also that of the apparent synonym, nearly without significant characterization. Since types of both plants are from Brazil near Rios Negro and Trombetas, the occurrence in Peru may be questioned. F.M. Negs. 18587, 18588.

Peru (fide Dahlgren). Brazil. "Irapay."

Lepidocaryum Tessmannii Burret, Notizbl. Bot. Gart. Berlin 10: 771.1929.

Original plants a few $\mathrm{cm}$. to 2 meters tall; petioles (as known) including sheathed portion about 1 meter long, stout, subglabrous, $6 \mathrm{~mm}$. broad below the leaf, this rigid, $7 \mathrm{dm}$. long or longer, concolored, 4-parted, the lateral incised $2 \mathrm{~cm}$. above the rachis, the subequal lobes $6.5-7.5 \mathrm{~cm}$. wide, the 5-6 primary nerves spinulose above as the inner margins of the inner lobes and the outer of the outer lobes; primary nerves 2 , prominent only above, intermediate secondary few, transverse, curved above; male spadix with peduncle-this $4.5 \mathrm{dm}$. long-nearly $8.5 \mathrm{dm}$. long, branches 6 or 7, lower 13-17 cm. long; primary spathes narrow, the free part $11 \mathrm{~cm}$. long, $4-5 \mathrm{~cm}$. wide, secondary funnelform, fuscous furfuraceous, caducous; flowering branchlets little exserted, without flowers for $8 \mathrm{~mm}$., the male flowers in about 7 rows, before anthesis nearly $1 \mathrm{~cm}$. long; calyx turbinate, $4 \mathrm{~mm}$. long, clearly and acutely dentate, densely striate as the linear petals, these $2 \mathrm{~mm}$. wide; female spadix nearly $5.5 \mathrm{dm}$. long, branched part $1.5 \mathrm{dm}$. long, the 4 branches 7-11 cm. long; flowers (before anthesis) at least $8 \mathrm{~mm}$. long, calyx half as long; fruit (after Tessmann drawing) scarlet, obovoid, $1.6 \mathrm{~cm}$. thick, $3 \mathrm{~cm}$. long with perianth and beak, this rather slender, acute, nearly $3 \mathrm{~mm}$. long.-Flowers rather white, seen on plants a few $\mathrm{cm}$. high; fruit eaten after it has been softened in water. Related to $L$. tenue Mart. with more numerous male spadix branches, flowers of both sexes smaller; less closely to L. gracile Mart. (author).

Loreto: Below Río Morona, (Tessmann 4906, type). "Irapay."

\section{CHEL YOCARPUS Dammer}

Reference: Burret, Notizbl. Bot. Gart. Berlin 10: 394-397. 1928. 
Trunk annulate, smooth as the flabellate leaves and ligulate petioles, these transversely rhomboid in cross section, obtusely margined, lightly bicanaliculate beneath and above, the ventral ligule triangulate, the dorsal shorter. Leaves basally multi-parted, the elongatecuneate apically laciniate, the laciniae minutely bidentate at tips. Fruiting spadix with only 2 spathe scars. Perianth segments 4 , free or nearly, coriaceous beneath the globose fruit, this with pseudosuberose tessellate epicarp similar to Pholidocarpus. Seed globose, broad raphe with few branches nearly to apex, embryo medially lateral.

Chelyocarpus Ulei Damm. Notizbl. Bot. Gart. Berlin 7: 395 (51). 1920.

Usually 3-4, rarely 6 meters tall, the remotely annulate stem 7 or $8 \mathrm{~cm}$. thick; sheath unknown; petioles to $7.5 \mathrm{dm}$. long, only $5-7 \mathrm{~mm}$. across, $3 \mathrm{~mm}$. thick, the angles obtuse; ligule at base of leaf 3 -angled, $1 \mathrm{~cm}$. wide, $8 \mathrm{~mm}$. long, extended as a $2 \mathrm{~mm}$. wide wing on the petiole, that at the leaf base beneath $2 \mathrm{~mm}$. long; leaves green above, more or less white silvery beneath, semicircular, 7-13-parted to base, the divisions $3.5-4.5 \mathrm{dm}$. long, $4-10 \mathrm{~cm}$. wide, 3-5-laciniate, these lobes 5-10 $\mathrm{cm}$. long with apical teeth 1-2 $\mathrm{mm}$. long; transverse nerves between the longitudinal many; spadix in fruit $6 \mathrm{dm}$. long, branched part $2.5 \mathrm{dm}$. long, early white-floccose, peduncle as rachis strongly compressed; scars $13 \mathrm{~mm}$. distant, upper about $8 \mathrm{~mm}$. from lower branch, lower nearly the same distance above the base; branches mostly simple, about $1.5 \mathrm{dm}$. long, $2-3 \mathrm{~mm}$. thick in herbarium, carinate-pulvinate below fruit, this globose, about $2.5 \mathrm{~cm}$. in diameter, spiralled, solitary, with a solitary short ovate bract.-Spadix description after Burret, l.c., who also considers the possibility that $C$. Wallisii (Wendl.) Burret, the seed (described fully by him) with uniform albumen, probably from Colombia or Ecuador, may belong to this genus or Tessmanniophoenix, the ripe seed of the latter unknown. Type of C. Ulei (Ule 5885) being from Río Juruá Mirim at the little community of Belém, nearly on the boundary with Peru, the species grows also no doubt within Peru, if environment is favorable. Illustrated, Burret, l.c. 12: 152 (photograph).

Loreto (surely). Adjacent Brazil.

\section{TESSMANNIOPHOENIX Burret}

Stems cylindric, smooth as the biconvex petioles, these with rounded margins, ligulate, the ligule protracted below the leaf-blade. Leaves palmate-flabellate, equally biparted nearly to base, the 2 divisions 
also divided. Spadix simply branched, the well-developed peduncle apparently with few deciduous spathes, none between the branches, these long-bracteate. Flowers solitary, hermaphrodite, sessile, 1bracted. Perianth erect, closed (anthers exserted), segments seemingly 4 , also irregularly 5 or 6 . Stamens 7,6 , or 8 , free. Filaments dilated, ovate, contracted above, anthers oblong, dorsally affixed near sagittate base, shortly incised at apex. Perianth little accrescent beneath globose fruit, the obscure stigmas apical. Pericarp thin, epicarp smooth, mesocarp probably fleshy, endocarp thin but subosseous.-Nearly Chelyocarpus Damm. which it resembles in petioles and division of the leaves and probably also in flowers, but wellmarked by the smooth pericarp according to the author, who comments (1.c. 11:500) on the validity of the genus as shown by $T$. dianeura Burret, from Colombia, also with short stout style, infundibuliform stigma as in Thrinaceae but that with calyx and corolla united and ordinarily only 1 carpel developed. The author (1.c. 12: 152-155) has distinguished the similar T. chuco (Mart.) Burret of Brazil, possibly to be found in Peru, by the leaves, which are basally divided into halves, while those of $T$. longibracteata resemble those of Chelyocarpus Ulei; photographs by $\mathrm{H}$. A. Johnstone presented by Burret show clearly this difference.

The noted ethnographer (Guenther Tessmann) made botanical collections with excellent data as noted elsewhere in this work; this generic name could be given greater euphony by omitting one connecting (repetitive) vowel, regardless of tradition. Tessmanniodoxa Burret (one of the repetitive consonants also not deleted), Notizbl. Bot. Gart. Berlin 15: 336. 1941, defining generically Thrinax chuco Mart., formerly included here by Burret (l.c. 10:400), is unlikely to be found in Peru.

Tessmanniophoenix longibracteata Burret, Notizbl. Bot. Gart. Berlin 10: 398. 1928; 11: 315. 1932.

Known to attain 5 meters, the stem $7 \mathrm{~cm}$. in diameter, the 10-15 leaves silvery beneath (except major nerves) with a dense or floccose puberulence as the younger spadices; petioles glabrous, rounded, striate (dried) above, 2 meters long or longer, $6 \mathrm{~mm}$. thick, below apex $1 \mathrm{~cm}$.; ligule fleshy coriaceous, triangular, smooth above, densely sulcate beneath, protracted below and free from the blade, this a meter long, membranous, divided to $3 \mathrm{~cm}$. above the base, the two parts semiflabellate, each cuneately $6-7$-lobed nearly to base, the 2 medial lobes the widest, scarcely medially incised into broad segments, these shortly 2 dentate; laciniae of lower lobes acuminate; longitudinal nerves 
many, transverse serpentine ones more obvious above; spathes 3 , the lowest $19 \mathrm{~cm}$. long, linear, $3 \mathrm{~cm}$. wide below, $3.5 \mathrm{~cm}$. above, the second extending about $2 \mathrm{dm}$. over the former, the third $2.5 \mathrm{dm}$. over the second, all rather strong but still soft, rather densely but evanescently floccose; spadix $8.5 \mathrm{dm}$. long, peduncle as rachis strongly compressed, 6-7 cm. thick, little attenuate, annular scars 2 (3), about $1.5 \mathrm{dm}$. distant, branches 1-1.5 dm. long, scarcely divergent, basal bract linear, $7 \mathrm{~cm}$. (type) to $2 \mathrm{dm}$. long, the upper shorter; perianth erect, subglobose, closed, anthers entirely exserted; perianth mostly irregular, segments nearly free, 4, also 6, rarely 5, glabrous; stamens mostly 7 (6 or 8), filaments free, subfiliform, anthers oblong, black punctate; carpels 2 , free, slightly contracted apically, stigma dilated, rounded; fruits on umbonate pulvinae from solitary spiralled flowers but rather irregularly and thus pseudoverticillate, the single elongate dorsal bract uncinate-curved; fruit depressed globose, $8 \mathrm{~mm}$. in diameter (immature); stigma obscure, scarcely excentric, sterile carpel present; perianth $7 \mathrm{~mm}$. across, segments apparently 4 , the 2 free sepals ovate, equaled by the alternating petals; mesocarp thin, endocarp hard, seed basal.-After author, who noted that he had little doubt of the identity of the flowering (Weberbauer) and fruiting specimens.

Huánuco: Ríos Pozuzo, Palcaza, (Weberbauer 6765, type); Tessmann 4830, fruit.-Junín: Capuahuanas, Río Pichis, (Killip \& Smith 26717). "Uchapanga."

\section{CAL YPTRONOMA Griseb.}

Reference: L. H. Bailey, Gentes Herb. 4: 153-172. 1938.

Resembles Geonoma in general and floral character, the filaments cupulate and tubularly connate below, but the sagittate-cordate parallel anther cells united to the connective, and the ovary, at least early, 3-celled. Leaf segments long-acuminate, often narrowly, even filiform-caudate. Peduncles of the laterally branched spadices elongate, the lower apically parted spathe much shorter.--Included by Burret in Calyptrogyne Wendl. but distinguished by Drude; Bailey (l.c. 156) emphasizes in contrast the arboreal habit, uniformly pinnate leaves, axillary rather than terminal spadix, 1-2-branched from a central axis, male and female flowers normally in same cavity anywhere on axis, style central, mesocarp firm-ligneous, marked with stout interlocking fibers or ribs; perhaps these characters, impressive as they seem, will be found to be similar developments, varying in degree. 
Spadix branches brownish-tomentose............. synanthera. Spadix branches white pruinose............... Weberbaueri.

Calyptronoma synanthera (Mart.) Bailey, Gentes Herb. 4: 166. 1938. Geonoma synanthera Mart. Hist. Nat. Palm. 2: 13, pl. 13. 1823. Calyptrogyne synanthera (Mart.) Burret, Bot. Jahrb. 30: 137. 1930.

Leaves 1-1.5 meters long, pinnatifid, the lanceolate acuminate pinnae subfalcate; male spadices branched, $3 \mathrm{dm}$. long or longer, flowers approximate, the corollas little exceeding calyx.-Otherwise unknown, but Burret (l.c.) observed that the vertical bract-enclosed ranks or lines of the flower pits are less marked, more delicate in contrast to the same characteristic, especially in C. robusta Trail of the upper Amazon and in C. Kalbreyeri (Burret) Bailey of Colombia, and, also, in contrast to the latter, the pits are less crowded; the obovoid fruits, $9 \times 12 \mathrm{~mm}$., are said by Burret to resemble those of the latter in size. C. robusta Trail (Journ. Bot. 330. pl. 183, fig. 3. 1876; Mart. Fl. Bras. pl.122) as to type had solitary erect stem to 5 meters tall, densely annulate, widely divaricate leaves $2-2.5$ meters long, 5-7 pairs of long-acuminate pinnae, nerves many, costa beneath furfuraceous, spadix 9-12 dm. long, spike $1.5 \mathrm{dm}$. long, 7-17-branched, pits 8-10-ranked, lip reflexed, flowers unknown, fruit ligneous, ellipsoid, $2 \mathrm{~cm}$. long, more than $1 \mathrm{~cm}$. thick, smooth, the mesocarp coarsely fibrous. Type of C. robusta from Rio Jauary, Brazil, and quite possibly is the little known C. synanthera or, in any case, it will be found in Peru. F.M. Neg. 18531.

Huánuco: Chicoplaya, (Ruiz \& Pavón, type). Brazil?

Calyptronoma Weberbaueri (Burret) Bailey, Gentes Herb. 4: 166. 1938. Calyptrogyne Weberbaueri Burret, Bot. Jahrb. 30: 139. 1930.

Type about 4 meters tall; petioles $6 \mathrm{dm}$. long, sheath short, early tomentose below (where $5 \mathrm{~mm}$. broad), toward apex acutely carinatecanaliculate, finally gradually applanate, $4 \mathrm{~mm}$. broad; leaf-segments laterally 7 , filiform caudate, rather regularly disposed, the largest apical ones $4.5 \mathrm{~cm}$. wide, 9.5-10.5 cm. long, 8- or 9-nerved, the nerves acute especially above, beneath (in herb.) brownish-paleaceous; upper spathe (incomplete in type) $22 \mathrm{~cm}$. long, brown within, paler without, deciduously ferrugineous tomentose as peduncle below, this compressed, 3- nearly $4 \mathrm{dm}$. long, at insertion of lower spathe $1.5 \mathrm{~cm}$. broad; spadix about $8 \mathrm{dm}$. long, the 10-13 simple branches white- 
pruinose, $6 \mathrm{~mm}$. thick, 2-2.5 dm. long, basal bract broadly ovate, reflexed, sterile base short; flower pits in 8 ranks, these $6 \mathrm{~mm}$. distant, but along 2 elevated lines rather well separated; pit bracts (lip) in fruit reflexed, $2.5 \mathrm{~mm}$. broad, lanceolate sepals then $3.5 \mathrm{~mm}$. long; fruit pruinose, obovoid, 11-14 mm. long, $8 \mathrm{~mm}$. thick, rounded apically, subincurved to nearly stiped base, epicarp branched-fibrous, strongly 14-nerved toward base.

Puno: Chunchusmayo, 900 meters, (Weberbauer 1234, type).

\section{GEONOMA Willd.}

Reference: Burret, Bot. Jahrb. 63: 144-266. 1930; second page references refer to descriptions by Drude in Mart. Fl. Bras. 3, pt. 2. 1882.

Smooth, slender, the trunk annulate, the terminal or alternate leaves entire, apically bifid or pinnatisect with acuminate segments, tubular sheath. Spadices variable in development, the lower of the 2 spathes (these usually caducous) incomplete, truncate, concave, the upper compressed or fusiform. Flowers glumaceous, unisexual, immersed in spirally or vertically disposed pits (1-3 in each), the central (if present) female developed after the male; both sexes with sepals slightly imbricate below, petals ciliate, connate toward base. Male flowers deciduous, filaments united into a truncate, entire, dentate or laciniate tube, the 6 (typically) anthers with free cells. Ovary 1-celled, ovule ascending, long style lateral, the 3 stigmas subulate. Fruit with fibrous usually thin pericarp; endosperm uniform.-G. multiflora Mart., 261, G. laxiflora Mart., 239, are scarcely to be expected within Peru, their known distribution being out-of-line with that of other Brazilian species extending into Peru; cf. also G. myriantha Damm.

It is certainly fortunate for the users of this work that Burret's key (l.c. 145-161) has been available; also, he has clearly presented his definition of the generic boundaries and his interpretation of the relative importance of specific characters. With laudable humility, he expressed his conviction that his key (and his conclusions) are pioneer studies.

\section{KeY TO GEONOMA}

(After Burret, inserts by me)

Staminodal tube cylindric, truncate or obscurely dentate (subgenus Eugeonoma Spruce). 
Spadix simple, rarely bifurcate (branches 3, G. Tessmannii).

Peduncles well-developed, subequaling or longer than spikes (see G. Tessmannii).

Alveoli oval, obliquely truncate, upper edge not produced; spathes two-thirds as long as spadix.

Leaf segments 3 pairs............... granditrijuga.

Leaf segments $5-8$ pairs............... gracilipes.

Leaf segments mostly 6 pairs...........G. multisecta.

Alveoli bilabiate, upper edge acute, extended; spathes often three-fourths as long as spadix.

Spathes one-half as long as spadices.

Leaf segments oblong-subquadrate.....G. Brongniartii.

Leaf segments cuneate-based............. cuneifolia.

Spathes two-thirds (at least) as long as spadices, equaling or exceeding pedicel...............G. adscendens.

Peduncles short, exceeded by spikes only a little (G. Tessmannii, spike small).

Leaves simple.

Spadix normally 3-branched, slender......G. Tessmannii. Spadix simple or branches stout.

Spikes $2-10 \mathrm{~cm}$. long.

Alveoli lips (lower) 7-8 mm. distant; spikes rather stout. G. Uleana.

Alveoli lips 4-5 mm. distant; spikes stouter.

G. pycnostachys.

Spikes 2-2.5 dm. long................ piscicauda.

Leaves pinnate..................... Raimondii.

Spadix branches 3 (2) -many.

Alveoli bilabiate, spiralled or verticillate, upper edge somewhat produced.

Spadix branches stout or alveoli spiralled.

Branches rather stout; flowers as alveoli mostly rather large.

Spathes narrow, often long-tubular, thin, the upper often high above lower.

Leaf segments $2-3$ pairs.............. andina.

Leaf segments 7 pairs................. G. floccosa.

Spathes broad, firm to coriaceous, subequal, little remote; leaf segments many. 
Alveoli subapproximate; some spadix branches branched. Spadix axis 7-9 mm. thick........G. Weberbaueri. Spadix axis 4.5-5.5 mm. thick....G. helminthoclada. Alveoli congested; spadix branches simple.

G. congestissima.

Branches slender; flowers as alveoli small.

Spadix branches 3 , slender, only to $6 \mathrm{~cm}$. long; leaves simple...................... Tessmannii.

Spadix larger or characters not as above.

Alveoli approximate.

Spathes 1.5-3.5 dm. long; branches usually simple.

G. interrupta.

Spathes as noted shorter; spadix branches long, 2-3branched.................. myriantha.

Alveoli laxly spiralled; leaves simple, oblanceolate.

G. leptospadix.

Spadix branches slender, alveoli alternate in verticils.

G. myriantha.

Alveoli uniformly edged; spathes more or less dilated, firm or inner membranous.

Branches stout; alveoli mostly subregularly in verticils.

G. megalospatha, G. andicola.

Branches slender; alveoli spiralled.

Leaves unevenly pinnate....G. Poeppigiana, G. interrupta.

Leaves evenly pinnate, segments 3 (4) pairs. . . G. Killipii.

Staminodal tube divided into 6 linear teeth (subgenus Astrandroecium Spruce; cf. Taenianthera Burret, staminodal tube dentate or lobate).

Alveoli in 5-6 series little inclined toward axis; leaf segments small. Leaf segments various, $1-7.5 \mathrm{~cm}$. wide.........G. Spruceana. Leaf segments (apical) rhombic, $1.5 \mathrm{~cm}$. wide, $2.5 \mathrm{dm}$. long.

G. camptoneura. Alveoli in 7-8 series; leaf segments larger.......... G. longisecta.

Geonoma adscendens Damm. ex Burret, Bot. Jahrb. 63: 175. 1930.

Finally erect, to 1 meter tall, $8 \mathrm{~mm}$. in diameter above; sheath amplexicaul, early membranous, $8 \mathrm{~cm}$. long, petioles about $2 \mathrm{dm}$. long, hardly $2 \mathrm{~mm}$. thick, leaves $28 \mathrm{~cm}$. long to the cleft (lobes nearly 
$1.5 \mathrm{dm}$. long), segments rather regularly 4 pairs, the broader upper slightly falcate, acuminate, $8 \mathrm{~cm}$. wide at rachis, the lowest $1.5-2 \mathrm{~cm}$. wide, primary nerves 26 or 27 in each lateral lobe, rather acutely prominent beneath, secondary nearly as high; spadices simple, flowering in axils of withered leaves, slender, about 2-3.5 dm. long, spathes narrow, apparently including the peduncles, these $12-25 \mathrm{~cm}$. long; floral pits laxly separated, bilabiate, upper lip shorter, acute, lower emarginate, axis nearly $2.5 \mathrm{~mm}$. thick, glabrous but minutely granulate; sepals (male) about $3.5 \mathrm{~mm}$. long, petals two-thirds connate, lobes ovate, staminal cup rather robust, female calyx (also before anthesis) nearly $3 \mathrm{~mm}$. long, petals about as male, staminodal tube about a third longer, truncate.-Perhaps comparable to G. arundinacea Mart., 180, Amazonian, the flowers mostly laxly spiralled in 3 series, the short peduncle conspicuously exceeded by the spike, the nerves about 20 (Burret).

Cuzco: Steep wooded outcrop, 1,700 meters, St. Anna above Hacienda Idma, (Weberbauer 5033, type). "Cuculli."

Geonoma andicola Damm. ex Burret, Bot. Jahrb. 63:218. 1930.

Leaves narrowly pinnate, the linear leaflets not at all falcate, the first broadest and only about $1 \mathrm{~cm}$. wide, the petioles apically $7 \mathrm{~mm}$. broad, rounded beneath, early leprose; primary nerve one, rather well-developed above, fuscous beneath with crowded narrow scales between the primary and secondary nerves (the latter marginal), the tertiary more or less developed, the larger minutely lepidote, others sparsely; spadices duplicately branched, glabrous, outer spathe subcoriaceous, $3.5 \mathrm{~cm}$. broad, $23 \mathrm{~cm}$. long, the inner reddish furfuraceous or glabrate; peduncle to $5 \mathrm{~cm}$. long, at base of lowest branch $7 \mathrm{~mm}$. thick; rachis to base of top branch $8.5 \mathrm{~cm}$. long, primary branches 8 , acutely angled, broadly bracted at base, the lower bifurcate, 2.5$3.5 \mathrm{~cm}$. pedunculate, the rest simple, the spikes foriferous to rounded tips, $11.5-14.5 \mathrm{~cm}$. long, axis $5 \mathrm{~mm}$. thick; alveoli in 6 nearly vertical series, 6 or $7 \mathrm{~mm}$. distant, the upper lip none, even fruiting margins rounded, the lower long-extended, always deeply emarginate; sepals $4.5 \mathrm{~mm}$. long, oblong; petals $4.5 \mathrm{~mm}$. long, these two-thirds connate, staminodal tube scarcely incised, subtruncate, exceeded $1 \mathrm{~mm}$. by stigmas; fruit at least $1 \mathrm{~cm}$. long, $6 \mathrm{~mm}$. broad, obscurely mammillate, densely elevated-lineolate; male flowers fallen.-Type noted as 4 meters tall.

Puno: Chunchusmayo, 1,500-1,800 meters, (Weberbauer 1345 , type; 573). 
Geonoma andina Burret, Bot. Jahrb. 63: 188. 1930.

Leaves (type) to $47 \mathrm{~cm}$. long, broadly elliptic, primary nerves on each side 18 or 19 , segments 3 pairs, strongly scattered, lightly falcate, acuminate, the basal nearly $4 \mathrm{dm}$. long, the apical on interior margin nearly $2 \mathrm{dm}$. long, $3.3-4.2 \mathrm{~cm}$. wide; primary nerves very prominent above, somewhat slenderer than the secondary beneath, toward the rachis furfuraceous, the tertiary many, obvious both sides, clearly shortly appressed-pubescent beneath, the primary nerves medial, segments of adult leaves $7 \mathrm{~mm}$. distant; spadix over $4 \mathrm{dm}$. long, the branched part $1.5 \mathrm{dm}$. long, the rachis $3 \mathrm{~cm}$. long, the spathes equaling three-fourths of the peduncle, the lower $14 \mathrm{~cm}$. long, applanate below, $1 \mathrm{~cm}$. broad, the upper $1 \mathrm{dm}$. above the lower; peduncle furfuraceous toward base, bracted above; branches 5 , basally bracted, axis in flower nearly $2.5 \mathrm{~mm}$. thick, 10-12 $\mathrm{cm}$. long or longer, granulose, extended into a slender spine; alveoli rather laxly spiralled, upper lip somewhat produced, lower incised; male flowers not open.

Cajamarca: Tambillo, Prov. Cutervo, (Raimondi, type). "Frutilla."

Geonoma Brongniartii Mart. Palm. Orbign. 24. pl. 12, fig. 1, pl. 23C, figs. 3, 5, 6. 1847; 174 .

A most attractive subacaulescent palm, the overall height only 1 meter (Ule), the 6 or 7 long leaves reddish beneath, clustered on a very short caudex - this with a few supporting roots - the few rufescent spadices erect; leaves about a meter long, the petioles shorter than the 2-3 pairs of oblong subquadrate acute segments, these to $1.5 \mathrm{dm}$. wide; primary nerves about 24 each side, more prominent beneath, the alternating secondary impressed above, nearly as incrassate as the primary below and scattered paleaceous, the slender tertiary many (7-9); spathes membranous, finally fibrous, outer 1.5, inner $2.5 \mathrm{dm}$. long; peduncles about $4 \mathrm{dm}$. long, the rachis about as long, cylindric, attenuate to acute mucro $12-15 \mathrm{~mm}$. long; early flowers female, soon (as usual) with 2 male in each remote pit, this with a broad emarginate bract or lip; calyx $2 \mathrm{~mm}$. long, lobes lanceolate, carinate, ciliolate, subequaling the ovate-oblong, subobtuse, marginally membranous sublacerate corolla segments; stamen tube urceolate; female rachis at maturity incrassate, red, the globose black fruits $8 \mathrm{~mm}$. in diameter.-Burret (1.c.) corrected Martius' description, noting the spadix as both male and female and that fig. 6 is incorrect as to scales; but cf. G. cuneifolia Burret. F.M. Neg. 38642.

Loreto (no doubt, as Ule 5593 nearly on the Brazilian boundary). Adjacent Brazil; Bolivia. 
Geonoma camptoneura Burret, Notizbl. Bot. Gart. Berlin 11: 201. 1931.

Rachis fuscous furfuraceous, the apical portion seen (19 cm. long) with widely divaricate membranous segments, $2.5 \mathrm{dm}$. long on upper margins, 14 or $15 \mathrm{~cm}$. wide, nearly rhombic, the outer margin subparallel to rachis; primary nerves 14 or 15 , sigmoid, strongly curved to margins, to $1.5 \mathrm{~cm}$. distant, secondary beneath nearly twice wider than primary, the many tertiary prominent both sides; spadix (fragment) $16.5 \mathrm{~cm}$. long, the 8 branchlets $10.5-13 \mathrm{~cm}$. long, minutely pilosulous but green, apically aculeate, the spine short, the male flowers immersed, axis nearly $3 \mathrm{~mm}$. thick, granulose; alveoli in 6 series little inclined, $4-5 \mathrm{~mm}$. distant; lower lip densely costate, somewhat protracted, subobtuse, the upper slightly but obviously extended from the axis; flowers mostly emerged at anthesis, the faded perianth $3.5 \mathrm{~mm}$. long, somewhat shorter than corolla; stamens long-exserted; staminode teeth 6, linear.-Reminds one of G. latisecta Burret with quite different leaf-segments.

\section{Loreto: Yurimaguas, Williams 7836, type.}

Geonoma congestissima Burret, Bot. Jahrb. 63: 224. 1930.

Arundinaceous, 4 meters tall (type); petioles $3 \mathrm{~mm}$. broad at apex, $2 \mathrm{dm}$. long or longer without sheath, this apically auriculate, early tomentose, the many nerves nearly vertical; leaf-rachis beneath as petioles scurfy, $3.8 \mathrm{dm}$. long, not at all extended; primary nerves 31 or 32 each side, prominent beneath, minutely lepidulous, tertiary above obsolete, beneath 7 between secondary and primary, finely appressed setulose; leaves membranous, subelliptic, to about $28 \mathrm{~cm}$. broad, to apices $53 \mathrm{~cm}$. long, to bifurcation $1.5 \mathrm{dm}$. long, the 3 pairs of distinct segments falcate, narrowly acuminate, $5-10 \mathrm{~cm}$. wide, to about $2.5 \mathrm{dm}$. long, interval between basal and medial pair nearly $7.5 \mathrm{~cm}$. long, primary nerves $8-10$ except shortly lobed terminal part 11-12-nerved; spadix about $2.5 \mathrm{dm}$. long, branches simple, 6-10, rachis $2.5-10 \mathrm{~cm}$. long, spathes subligneous, early fulvous tomentose, $1 \mathrm{dm}$. long, $2 \mathrm{~cm}$. broad at apex, peduncle 8-16 cm. long, spikes very dense, about 7-11 cm. long, before anthesis 8-10, in fruit $15-17 \mathrm{~cm}$. in diameter, axis alveolate to rounded apex; alveoli approximate in 7 series, the parts 3-3.5 mm. distant; upper as lower lip short, the latter rounded, finally often reflexed, entire; male sepals before anthesis nearly $4 \mathrm{~mm}$. long, the outer spathulate, $1 \mathrm{~mm}$. wide, petals to $3.25 \mathrm{~mm}$. long, to one-half connate, staminal cup (without stipe) $1 \mathrm{~mm}$. long, as filament to connective, this to $0.75 \mathrm{~mm}$. long, black, 
anthers $2 \mathrm{~mm}$. long; female sepals oblong, $4 \mathrm{~mm}$. long, as petals, these to one-half connate, the staminodal tube little shorter, scarcely incised; fruits congested, subglobose, $7 \mathrm{~mm}$. in diameter, $6 \mathrm{~mm}$. long, broadly rounded and submammillate apically, broadly protracted basally, minutely tuberculate, epicarp membranous, mesocarp finely fibrous, endocarp cartilaginous.

San Martín: Among shrubs, 1,300 meters, Moyobamba, (Weberbauer 4560, type).

Geonoma cuneifolia Burret, Notizbl. Bot. Gart. Berlin 11:199. 1931.

Simulates G. Brongniartii but the caudex developed, leaves about 2 meters long or longer, segments definitely cuneate at base, the lower 5-7 $\mathrm{cm}$. wide and with many more primary nerves; peduncle to $5.5 \mathrm{dm}$. long; spadix 6-8 dm. long, the spike $2 \mathrm{dm}$. long, $3 \mathrm{~mm}$. thick.-The much larger leaves with basally long-cuneate segments may distinguish this species from the one to which the author originally referred the type.

Loreto: Río Ucayali, (Tessmann 3317, type).

Geonoma floccosa Damm. ex Burret, Bot. Jahrb. 63: 203. 1930.

Type a meter tall, petioles $4.5 \mathrm{dm}$. long, at apex $3 \mathrm{~mm}$. thick, canaliculate above, basally vaginate; rachis nearly $3.5 \mathrm{dm}$. long; primary nerves 22 or 23 ; segments on each side about 7, apical broadest (primary nerves about 7), 14-20 cm. long, mostly $3-3.5 \mathrm{~cm}$. wide, but sometimes narrower, basal primary nerves about 7, basal segments nearly $2-2.5 \mathrm{~cm}$. wide, all falcate; nerves subequal except tertiary, these obscure above, rather many beneath, sparsely and minutely pubescent; spadix $5 \mathrm{dm}$. long, simply branched; spathe narrow, to $34 \mathrm{~cm}$. long, subequaling or little longer than peduncle, this as branches densely long-floccose-tomentose, somewhat unevenly deciduous; upper bracts oblong; rachis not flexuose at union with the 7 or 8 divergent branches; alveoli rather densely spiralled in 5 series little inclined toward the axis and after anthesis equally 5 or $6 \mathrm{~mm}$. distant, the upper lip clearly extended, the lower often cleft; male flowers emerged; fruit subglobose, apiculate at base, rounded at apex, $1 \mathrm{~cm}$. long, half as broad, densely and coarsely verruculose, endocarp little exceeding one-third $\mathrm{mm}$., the seed $7 \mathrm{~mm}$. in diameter.-Flowers brownish-purple (collector).

Junín: Low moist shrub-wood, west of Huacapistana, (Weberbauer 2277, type). 


\section{Field Museum of Natural History-Botany, Vol. XIII}

Geonoma gracilipes Damm. ex Burret, Bot. Jahrb. 63: 173. 1930.

Original plant recorded as only $1 \mathrm{dm}$. tall, the fuscous-leprose petioles and leaf-rachis each about $3.8 \mathrm{dm}$. long; segments (each side) $5-8$, mostly $1.5-2.5 \mathrm{~cm}$. apart, all or nearly all with many primary nerves, falcate, long-acuminate, the broader apical $15-17 \mathrm{~cm}$. long, 4-5 cm. wide; primary nerves each side about 28 , to $7 \mathrm{~mm}$. distant, subequaling the secondary, the tertiary conspicuous beneath; spike $7.5-11 \mathrm{~cm}$. long, including the more or less spinescent tip, the axis to $4 \mathrm{~mm}$. thick, alveoli densely in 6-7 series; sepals $2.25-2.5 \mathrm{~mm}$. long, ovate-oblong, the petals $3 \mathrm{~mm}$. long, staminodal tube subentire; fruit subglobose, minutely granular, $6 \mathrm{~mm}$. in diameter, the pericarp one-third mm. thick; male flowers unknown.-G. Jussieuana Mart. (Palm. Orbign. 24. pl. 12, fig. 2, pl. 23A. 1847), to which Burret (172) with doubt referred the following, may prove to be the same but, as he noted, the species of Martius ex char. (mostly from description and drawing of D'Orbigny) and from illustrations has petiole much shorter than leaf-rachis, peduncle and spadix subequal, in contrast to the specimen of Weberbauer with petioles and leaf-rachis subequal, peduncle and spadix very unequal; also, if the same species, and variety, it would be more expected in southern Peru as the type is from northeast of Cochabamba, Bolivia.

San Martín: Shrub-wood, 1,100 meters, Moyobamba, (Weberbauer 4557, type).

\section{Geonoma granditrijuga Burret, Bot. Jahrb. 63: 171. 1930.}

Low (type 2 meters), the leaves, apparently, regularly with 3 pairs of subequal and subequally disposed segments, all glabrous, the terminal one $14 \mathrm{~cm}$. decurrent, nearly $10 \mathrm{dm}$. long to the bifurcation, this to apex of lobes $3.7 \mathrm{dm}$., upper margins direct, narrowly acuminate, apex little falcate, the medial to $9 \mathrm{~cm}$. wide; primary nerves finally arcuate, 34 or 35 on each side, strongly prominent only above, the secondary half as high, the tertiary fine, especially beneath; spadix simple, peduncle and spike subequal, $21 \mathrm{~cm}$. long or longer, 2.5$3 \mathrm{~mm}$. thick below spike, lower spathe $12-14 \mathrm{~mm}$. long, narrow, robust, spike apex caudiform-spiniform, $1 \mathrm{~cm}$. long, $3 \mathrm{~mm}$. thick, leprose; alveoli in 6 exactly vertical lines, the parts of each equally $5 \mathrm{~mm}$. distant; sepals of male flowers $2.25 \mathrm{~mm}$. long, the outer ovate, the rest ovate-oblong; petals two-thirds connate; staminal cup stout, anthers nearly $1.5 \mathrm{~mm}$. long to tip of connective; sepals of female (young) ovate-oblong, acute, staminodal tube obscurely dentate.- 
Spadix of 3672 , male flowers emerging, nearly $7.5 \mathrm{dm}$. long, lower spathe $3.2 \mathrm{dm}$. long, linear, subligneous, to $16 \mathrm{~mm}$. broad, upper scarcely longer, peduncle nearly $4.5 \mathrm{dm}$. long, about $12 \mathrm{~cm}$. larger than spathe, spike to spine-like tip $2.85 \mathrm{dm}$. long. This inflorescence doubtless belongs here (author); so, why not include the measurements above?

Huánuco: Sparse woods, 700 meters, Monzón to the Huallaga, (Weberbauer 3673, type; 3672).

Geonoma helminthoclada Burret, Bot. Jahrb. 63: 222. 1930.

Leaf-rachis dorsally plane, glabrous, narrowly triangular toward the filiform extension; segments irregularly aggregate, at base very narrowly reduplicate, $1.5 \mathrm{~cm}$. wide, midrib above more or less prominent, beneath the one strong nerve besides the marginal, the tertiary obsolete; spadix (fragment) twice branched or more, peduncle $6.5 \mathrm{~cm}$. long, extending into 4 branches $3-3.5 \mathrm{dm}$. long, $4.5-5.5 \mathrm{~mm}$. thick, minutely tuberculate, rounded (espinose) apically; alveoli in 3 alternating verticils, upper lip moderately but conspicuously and thinly produced, the lower split, the series 8-9 $\mathrm{mm}$. distant; female flowers under anthesis $1 \mathrm{~cm}$. long, staminodal tube equaling petals, truncate, scarcely incised.-Recalls the much more northern G. undata Klotzsch, 213 , but the leaves, from the single apical fragment seen, appear to be distinctly different (author).

Amazonas: Chachapoyas, (Raimondi 509, type).

Geonoma interrupta (R. \& P.) Mart. Hist. Nat. Palm. 2: 8, pl. 7. 1823; 249. Martinezia interrupta R. \& P. Syst. Veg. 296. 1798.

Type a few meters tall, leaves unequally and interruptedly pinnate, segments linear-oblong, falcate-acuminate, multinerved, $4 \mathrm{dm}$. long or longer; inner spathe coriaceous, cuspidate, $2.5 \mathrm{~cm}$. broad, linear-cuspidate, unevenly grayish tomentose; spadices branched below, the rarely bifid branches $1.5 \mathrm{dm}$. long or longer, shortly attenuate, sparsely puberulent; flowers more or less approximate, 5 -seriate, about $2 \mathrm{~mm}$. long, calyx 3 times shorter than or equaling(?) corolla, lobes strongly concave, subserrulate; staminodal cup (female flowers) about as long as corolla; fruit globose; acute, about $4 \mathrm{~mm}$. in length. -After Martius who seems not to have seen the earlier developed male flowers as he notes distinct female and male spadices.-G. euspatha Burret (Notizbl. Bot. Gart. Berlin 11: 10.1930) from adjacent Colombia has larger flowers, the male $2.5 \mathrm{~mm}$. long, spathes much 


\section{Field Museum of Natural History-Botany, Vol. XiII}

longer; it is one of several Colombian species proposed in the same paper that may be expected in Peru. F.M. Neg. 18509.

Huánuco: Cuchero, Pozuzo, (Ruiz \& Pavón, type). "Cuyol," "siasia," (Ruiz \& Pavón), "chica-chica." 1932.

Geonoma Killipii Burret, Notizbl. Bot. Gart. Berlin 11: 320 .

Stems arundinaceous, the small leaves with 3 pairs (rarely a fourth reduced pair) of leaflets on a rachis $23 \mathrm{~cm}$. long, the slender petiole concave above; leaf-blade $33 \mathrm{~cm}$. long, paler beneath, primary nerves 22 each side; leaflets falcate, the apical twice as wide as the medial, these longer, the basal nearly directly divaricate, sigmoid, half as wide as the medial, all very narrowly long-acuminate; secondary and primary nerves equally strong beneath; peduncle $4 \mathrm{~cm}$. long, rachis 5 $\mathrm{cm}$. long, verrucose as the 8 branches, the 2 lower of these furcate, all slender, at most $1.5 \mathrm{~mm}$. thick at internodes; alveoli deep, lower margin produced, inflated, truncate, the upper obscurely extended, rarely spiralled, often decussate, $3-4 \mathrm{~mm}$. distant; fruit (dried) black, subglobose, at least $5 \mathrm{~mm}$. in diameter.-The detached leaf (26532) scabrous, petiole (above sheath) $2.5 \mathrm{dm}$. long, rachis $3 \mathrm{dm}$. long, uppermost leaf segments $13.5 \mathrm{~cm}$., decurrent, upper margin $1 \mathrm{dm}$. long, medial 6-7 cm., length of rachis $13 \mathrm{~cm}$. on margin, at most 6-6.5 $\mathrm{cm}$. wide, lowest segments 1.7-2 cm. long (rachis), $1.5 \mathrm{dm}$. on upper margin, at most $3.5 \mathrm{~cm}$. wide; spadix $19 \mathrm{~cm}$. long.-Similar to G. paniculigera Mart. but with smaller slender leaf-segments; the alveoli are not spiralled or 3-whorled, but placed crosswise (author).

Junín: Puerto Bermudez, (Killip \& Smith 26594, type; also 26532).

Geonoma leptospadix Trail, Journ. Bot. 14: 327, pl. 183, fig. 2. $1876 ; 230$.

Caudex reed-like, 1.5-2 meters tall, fulvous, glabrous; leaves 10-12 (petioles $4-5 \mathrm{dm}$. long, sulcate above), the beaks about $1 \mathrm{dm}$. long, long-decurrent, simple, bifurcate, the deltoid segments about $4 \mathrm{~cm}$. wide; primary nerves faint, 27 pairs; spadices $3-14$, in flower and fruit on same plant, reddish, 2.5-4 dm. long, peduncle to $2 \mathrm{dm}$. long, spadices finally often inflexed, 3-5-branched, flower pits scattered, obscurely 5-ranked, bract 2-lobed or emarginate; male sepals and petals subequally, medially connate; sterile staminal tube of female flowers subentire or minutely 6 -denticulate; fruit globose, $6 \mathrm{~mm}$. in diameter, black-purple.-Stem usually partly buried; in one plant I found 14 spadices, the lower ten in fruit (author). Recorded, besides lower 
Amazon (type locality), at Juruá Mirim, Brazil, near Peruvian boundary (Ule 5516, 5516b, det. Burret). F.M. Neg. 38651.

Peru (no doubt). Amazonian Brazil. "Ubim."

\section{Geonoma longisecta Burret, Bot. Jahrb. 63: 257. 1930.}

Type 2 meters tall with 12 very rigid leaves each with 2 pairs of approximate $(2-2.5 \mathrm{~cm}$. distant) leaflets, these little falcate, the lower $8 \mathrm{dm}$. long, about medially $7 \mathrm{~cm}$. wide, apical about $7 \mathrm{dm}$. long or longer on upper margin, $1 \mathrm{dm}$. wide, the apices not seen; rachis filiform-produced, fuscous scurfy beneath; primary nerves of larger segments nearly direct, very prominent above, obscure, scaly beneath, the secondary impressed above, very prominent beneath, the tertiary there more obvious than above; peduncle $4.5 \mathrm{~cm}$. long, $6 \mathrm{~mm}$. thick at apex, the partly twice branched spadix $2.5 \mathrm{dm}$. long, nearly $3 \mathrm{dm}$. wide; rachis $1 \mathrm{dm}$. long, branches 12, the upper 6 simple, in flower 9.5-11.5 cm. long, axis $2.5 \mathrm{~mm}$. long, pilosulous-granulose, alveolate to spineless tip; alveoli in 7 series, upper lip thin-margined, lower produced, often emarginate; stamens $2.5 \mathrm{~mm}$. long, petals not exserted; female flowers (early) scarcely $2 \mathrm{~mm}$. long, staminodal tube exserted, teeth linear; fruit oval, rounded both ends, about $13 \mathrm{~mm}$. long, $11 \mathrm{~mm}$. broad, densely and minutely granular, pericarp at least $1 \mathrm{~mm}$. thick, seed $1 \mathrm{~cm}$. long, $9 \mathrm{~mm}$. broad.-Resembles G. Spruceana Trail with much shorter and narrower leaf segments and with the spadix rachis marked by the terminal flowers overreaching the spineless point.

Loreto: Flood-free wood, Iquitos, (Tessmann 5087, type).

Geonoma megalospatha Burret, Bot. Jahrb. 63: 218. 1930.

A larger counterpart of $G$. andicola Damm., the type 6 meters tall, petioles apically $9 \mathrm{~mm}$. broad, filiform rachis extension stouter, about $5 \mathrm{~mm}$. long, leaflets nearly $12 \mathrm{~mm}$. wide, tertiary nerves 7-9; spadices deciduously furfuraceous, outer spathe $36 \mathrm{~cm}$. long, at base 5.5 , medially $6.5-7 \mathrm{~cm}$. broad, coriaceous; lowest branch spadix to apex $37 \mathrm{~cm}$., rachis to base of ultimate branches $23 \mathrm{~cm}$. long, primary branches 13, upper 7 simple, lowest to $7 \mathrm{~cm}$. pedunculate, spikes $16-17.5 \mathrm{~cm}$., axis $7 \mathrm{~mm}$. thick; sepals nearly $5 \mathrm{~mm}$. long, petals 4.5 $\mathrm{mm}$. long; fruit stoutly stiped (stipe 2-3 $\mathrm{mm}$. long), rounded at base, obscurely apiculate, including stipe $13 \mathrm{~mm}$. long, $9 \mathrm{~mm}$. broad, lightly rugulose, yellowish, pericarp nearly $1.25 \mathrm{~mm}$. thick.-In all parts, notably spadix, larger and more robust; the spathes are nearly twice as long and wide, spadix branches thicker, longer, pinnae wider 
(author). To an ecologist this vigorous condition resulting in greater size may suggest maximum natural conditions, to a horticulturist, a personal achievement in providing them. Grows with Ceroxylum crispum Burret at the altitudinal boundary for Peruvian species of palms.

\section{Huánuco: Pozuzo, (Weberbauer 6800, type).}

Geonoma multisecta Burret, Notizbl. Bot. Gart. Berlin 12: 155. 1934. Taenianthera multisecta Burret, l.c. 11: 13. 1930. T. Weberbaueri Burret, Bot. Jahrb. 63: 269. 1930, fide Burret, l.c., 1934.

Type like Taenianthera acaulis in habit; petioles (triangular) as leaf-blade to base of uppermost furcate segment about $7 \mathrm{~cm}$. long; remaining segments mostly 6 pairs, long-cuneate to base, upper to 6.5 , rest mostly 4-6 $\mathrm{cm}$. wide, all falcate, narrowly acuminate; primary nerves many; spadix simple, about $14 \mathrm{~cm}$. long, peduncle $12 \mathrm{~cm}$. long or longer; spathes slender, narrowly vaginate, not half as long as peduncles; spike $16.5-21.5 \mathrm{~cm}$. long, $8 \mathrm{~mm}$. broad including bracts, the nearly concealed axis $5 \mathrm{~mm}$. broad; pits densely congested even in fruit, in 7 series, little inclined; lower lips strongly extended, deeply incised, in each series $4-5 \mathrm{~mm}$. distant; sepals $3.25 \mathrm{~mm}$. long, oblonglanceolate, subequaling petals, to two-thirds connate; fruit oval, 9 $\mathrm{mm}$. long, $6 \mathrm{~mm}$. thick, densely tuberculate, little protracted at base.-After seeing more material with very irregular segments I believe that $T$. Weberbaueri is not distinct (author).

Huánuco: In shrub-wood, Monzón, 900 meters, (Weberbauer 3450, type of T. Weberbaueri). Adjacent Colombia.

Geonoma myriantha Damm. Verh. Bot. Ver. Brandenb. 48: 1. 1906 (1907); 236. G. paniculigera Mart. var. papyracea Trail, Journ. Bot. 16: 326. 1876; fide Burret, with query.

Type 4 meters high, with several broadly oval interrupted-pinnate ( 3 pairs) leaves to $4.5 \mathrm{dm}$. broad; petioles to $7 \mathrm{dm}$. long, the juvenile bright brown; rachis about $5 \mathrm{dm}$. long, nerves (each side) about 28; leaf divisions 6-8 cm. distant, the lower 7, medial 12, uppermost 18 $\mathrm{cm}$. wide; spadices lax, lower branch much branched, all filiform to $3 \mathrm{dm}$. long, $2 \mathrm{~mm}$. thick, the lower pedicels closely brown-red verruculose; alveoli $2-3 \mathrm{~mm}$. distant, 5-ranked; male flowers reddish, scarcely $2 \mathrm{~mm}$. long, outer segments carinate, inner ovate-lanceolate; filaments basally connate, anther cells linear.-G. Heinrichsiae Burret (Notizbl. Bot. Gart. Berlin 12: 43. 1934) of Ecuador has laxly disposed alveoli. Type, Ule 5882, from nearly at the boundary, as the 
variety of Martius' species; the latter, known from southern Colombia not very far from the Río Putumayo, is distinguished apparently chiefly by thin, often split lower lip of the flower pits; the species may be found to merge. G. laxiflora Mart., 239, from lower Río Purus, etc., is marked by the simple or little separated 2 pairs of leaf segments, and especially by the laxly disposed verticils, these with intervals 2-3 times longer than the alveoli themselves.

Loreto (certainly). Adjacent Brazil; Bolivia.

Geonoma piscicauda Damm. Verh. Bot. Ver. Brandenb. 48: 122. 1906 (1907); 182. G. Wittiana Damm. l.c. as to spadix (Burret); cf. Hyospathe brevipedunculata Damm.

Low (1-2 meters), apparently branched at base, with simple leaves, the sheath at least $1 \mathrm{dm}$. long, truncate, petioles $16 \mathrm{~cm}$. long, $3 \mathrm{~mm}$. thick, leaf-blade elongate-obovate, apically bifid, $5 \mathrm{dm}$. long, $21 \mathrm{~cm}$. broad, rachis $5 \mathrm{dm}$. long, primary nerves 30 each side; outer spathe $7 \mathrm{~cm}$. long, spadix simple, cylindrical, (peduncle 7-8 [13] $\mathrm{cm}$. long), about $2.5 \mathrm{dm}$. long, 7-10 mm. in diameter, alveoli 7-ranked, 7-10 mm. distant; male calyx lobes conchiform, carinate, ciliate, 3 (4) $\mathrm{mm}$. long, corolla lobes ovate, acute, 3.5 (4) $\mathrm{mm}$. long; filaments $5 \mathrm{~mm}$. long, anther cells $1.5 \mathrm{~mm}$. long; female calyx lobes ovate, acute, $5 \mathrm{~mm}$. long, corolla tube subglobose, $2 \mathrm{~mm}$. long, lanceolate lobes $4 \mathrm{~mm}$. long; style trifid, $5 \mathrm{~mm}$. long; fruit subglobose, $6 \mathrm{~mm}$. in diameter, 7-8 mm. long, attenuate toward base.-Type from Juruá Mirim (Ule 5520), nearly at the Peruvian boundary; G. Wittiana Damm. l.c. 124 (at least very near, Burret) from neighboring Seringal Belém (not Pará).

Peru (no doubt). Brazil.

Geonoma Poeppigiana Mart. Palm. Orbign. 35. 1847; 263.

Leaves unevenly pinnate, younger leaves divided into few segments, 7.5-10 cm. long, adult a meter long or longer with 6-8 segments, these linear-oblong, $4 \mathrm{dm}$. long or longer, $12-25 \mathrm{~mm}$. wide, opposite or subalternate, attenuate into an acutely falcate acumen; petioles convex below (as rachis), concave above, sparsely reddish tomentose as younger leaves beneath, the peduncles (to $5 \mathrm{dm}$. long) and spadices in part densely so; primary nerves acutely prominent only above, the alternating secondary nerves there impressed, stout below, in age hard, pale, glabrous; outer spathes linear, $2 \mathrm{~cm}$. wide, subcoriaceous; male spadix simply few-branched (rarely entire), the acutely mucronate (mucro 4-20 mm. long) branches 3-4 times shorter 
than the long peduncle, the naked part reddish verrucose-squamate; bractlets acute, binate or ternate toward apex of peduncle and at base of branches, these 2-5, always simple, each erect; peduncles of branches $6-10 \mathrm{~mm}$. long; rachis with the crowded immersed flowers cylindric, the series mostly 8 , obliquely spiralled, the lip of the alveoli entire; male calyx subequaling corolla.-Size and color of flowers of G. interrupta, calyx segments suboblong, corolla lobes ovate, acute, same color and texture, the staminodal cup shortly dentate, but unlike G. interrupta in the membranous inner spathe (Martius); Burret (Notizbl. Bot. Gart. Berlin 11: 321. 1931) applied this name, obscurely understood, to the following collections but without new characterization.

Huánuco: Cuchero, (Poeppig, type).-Loreto: Yurimaguas, (Killip \& Smith 28026). Santa Rosa, (Killip \& Smith 28729).

Geonoma pycnostachys Mart. Hist. Nat. Palm. 2: 16, pls. 17, 21, fig. 1. 1823; 181; 503 (Drude).

A meter or two high, the remotely annulate stem less than a cm. thick; leaves $10-12$, simple, spreading, narrowly elliptic or oblongspathulate, one-fifth to one-sixth bilobed, apical divisions broadly ovate, inflexed-acuminate, the entire leaves 3-4 dm. long, 10-12 $(-17) \mathrm{cm}$. wide, petioles $5-8 \mathrm{~cm}$. long; primary nerves each side about 30 ; spadices erect-spreading, $12-16 \mathrm{~cm}$. long, ferrugineous lepidote, the short peduncle gradually incrassate into the $9-12 \mathrm{~cm}$. long rachis, this in flower more than $1 \mathrm{~cm}$. thick, acute; alveoli exserted, approximate in 8-10 series, the long-produced lip orbicular; flowers reddish, male corolla semitrifid, staminal cup short-funnelform, female scarcely half as long as trifid calyx, long exceeded by the cylindric staminodal cup, this 6-denticulate; fruit ovoid, obtuse, $6 \mathrm{~mm}$. long, olive-black.Male flowers carmine red, subpersisting (collector). F.M. Neg. 18523.

Loreto: Flood-free terrain, mouth of the Santiago, (Tessmann 4446). Amazonian Brazil.

Geonoma Raimondii Burret, Bot. Jahrb. 63: 182. 1930.

Leaves (in fragment seen) pinnate, the segments rigid, dark green above, $4.5-6 \mathrm{dm}$. long, $8.5 \mathrm{~cm}$. wide; primary nerves $4-9$, direct, $1 \mathrm{~cm}$. distant, prominent above, beneath much slenderer than the secondary, the intermediate tertiary 12-14, minutely appressed setulose, densely pale puncticulate; upper spathe $2.5 \mathrm{~cm}$. above the lower; peduncle above shortly ovate-bracted, tuberculate, little shorter than the stout spike, this with fertile female flowers to $12 \mathrm{~mm}$. in diameter; 
alveoli in 7-8 series little inclined, 5 more inclined, lower lobe broadly rounded, entire; flowers more than half emerged, sepals and petals finally subequal and exceeded by the narrow staminodal tube, this obscurely 6-dentate; fruit ovoid, faintly striate, $11 \mathrm{~mm}$. long, $5 \mathrm{~mm}$. broad, pericarp thin, endocarp within fuscous, the seed $7 \times 4 \mathrm{~mm}$., male flowers unknown.-G. Trauniana Damm., 183, from the lower Juruá is similar but has many leaf-segments, all except the apical with only 2-3 primary nerves; G. Trailii Burret, 183, upper Amazonian, has leaves with 3-4 pairs of sigmoid leaf-segments, 22 primary nerves on each side.

Amazonas: (Raimondi 978, type). "Palmide."

Geonoma Spruceana Trail, Journ. Bot. 14: 328. 1876; 256. G. juruana Damm. Verh. Bot. Ver. Brandenb. 48: 119. 1907, fide Burret.

Stems 3 or 4 to 5 meters tall (type), $2.5 \mathrm{~cm}$. thick; leaves $3-7 \mathrm{~cm}$. long (with petiole), the 2-21 pinnae lanceolate-rhombic, ligulate or grass-like, subfalcate, 3-6 (7.5) dm. long, 1-7.5 cm. wide, subcoriaceous, concolor, primary veins 11-15 pairs, the sublinear blades always 3-nerved; spadices 2-3 (4) dm. long, reddish or green, branches 4-8, simple or 2-8-branched below; peduncle to $1 \mathrm{dm}$. long, compressed; spathes lanceolate, obtuse, $7 \mathrm{~cm}$. to nearly $2 \mathrm{dm}$. long, coriaceous; flower pits 5-7-ranked; male calyx membranous, segments $3 \mathrm{~mm}$. long; staminal tube 3 -crenate but splitting into 6 teeth or 6-lobed from the first; fruit oval or subglobose, $6 \mathrm{~cm}$. $\times 1.2$ cm.--After Trail, who designated several Brazilian variants, with doubt as to their taxonomic validity. Burret adopted two: var. intermedia Trail, leaves multisected, smaller, segments denser, and var. compta Trail, leaves larger, segments laxer. He cites Trail 17r from Tabatinga, at the Brazilian boundary with Loreto, as typical, but the collection is not listed by Trail, l.c., unless it is an error for 170, 176 or 174; type of Dammer's species (Ule 5744), however, was from mouth of Río Juruá Miry (Mirim) nearly at the Peruvian boundary. G. Spixiana Mart., 263, little known, as to Maynas (Yurimaguas) specimen by Poeppig may be this; Martius himself suggested he might be mistaken in considering it the same as a species of Bahia, Brazil.

Peru (surely; see note above). Amazonian Brazil.

Geonoma Tessmannii Burret, Bot. Jahrb. 63: 181. 1930.

Stems several from the same rhizome, $9 \mathrm{~mm}$. thick, lustrous, the upper internodes $1 \mathrm{dm}$. long; sheaths $1 \mathrm{~cm}$. long; petioles $12 \mathrm{~cm}$. long; 
leaves simple, often laterally cleft, never disjoined, obovate-lanceolate, shortly cuneate at base, upper to $17.5 \mathrm{~cm}$. wide, $4.5 \mathrm{dm}$. long to apex, about one-fifth bifurcate, upper margin $14.5 \mathrm{~cm}$. long, lobes shortly acuminate, membranous, paler beneath; primary nerves 26 both sides, slightly curved near rachis, the secondary subequal beneath, the tertiary obscure above, about 8 visible beneath; spadix 1 $\mathrm{dm}$. long, branches 3 ; upper spathe (fragment) $7 \mathrm{~mm}$. long; peduncles about $5 \mathrm{~cm}$. long ( 2 broadly rounded, nearly truncate bracts), at apex $2 \mathrm{~mm}$. thick, as branches densely granulose, these $5-6 \mathrm{~cm}$. long, spikes $4.2-4.6 \mathrm{~cm}$. long, dense, pits in 5 or 6 vertical series, bilabiate, lower lip inflated, emarginate; male flowers more than one-half emerged, $3 \mathrm{~mm}$. long, stamens exserted $4 \mathrm{~mm}$.; staminodal tube of female flowers denticulate.

Loreto: Non-inundated woods, mouth of Río Santiago, (Tessmann 4225, type).

Geonoma Uleana Damm. Verh. Bot. Vèr. Brandenb. 48: 122. $1906 ; 181$.

Stems scarcely $5 \mathrm{~mm}$. thick, the annuli $1.5-3.5 \mathrm{~cm}$. distant; sheaths cylindric, fibrous, oblique, $6 \mathrm{~cm}$. long; petioles about $12 \mathrm{~cm}$. long, $2 \mathrm{~mm}$. thick, leaf-rachis $18 \mathrm{~cm}$. long, the oblong leaf attenuate to base, apically bifid, the lateral margins quite parallel, $2-2.5 \mathrm{dm}$. long, 7.5-10.5 cm. wide; primary nerves 18-20, early, as rachis, floccose-pilose; spadices in the older or lower axils, the included simple peduncles $3 \mathrm{~cm}$. long, spathe 5-6 $\mathrm{cm}$. long; spadix 7-11 $\mathrm{cm}$. long, $3 \mathrm{~mm}$. thick, alveoli deep, $5 \mathrm{~mm}$. distant, 4-ranked; fruits apiculate.-Type, Ule 5521, mouth of Río Tejo, near Peruvian boundary.

Loreto: Iquitos, (Ule 6879). Adjacent Brazil.

Geonoma Weberbaueri Damm. ex Burret, Bot. Jahrb. 63: 221. 1930.

Type 6 meters tall, the caudex about $5 \mathrm{~cm}$. in diameter at the great spadix, this a meter and a half long, cernuous, duplicatebranched, early furfuraceous; leaves $16 \mathrm{dm}$. long with petiole, this $1 \mathrm{dm}$. long, $12 \mathrm{~mm}$. broad at apex, at apex of sheath $16 \mathrm{~cm}$. broad; leaf-rachis above as petioles early broadly canaliculate, finally subplane, apex not at all produced; segments 1-nerved, linear, attenuate but not at all falcate, middle 10-12 $\mathrm{mm}$. wide, diminished upward; primary nerve prominent above, acute beneath, marginal secondary broader beneath than primary, tertiary partly obvious, intervals 
beneath minutely white puncticulate; peduncle about $2.5 \mathrm{dm}$. long, somewhat shorter than branched part, rachis $57 \mathrm{~cm}$. long, branches often 20 , the 12 lower branched, the lowest with about 10 simple branches; spikes floriferous to summit, not spine-tipped, to $3 \mathrm{dm}$. long, axis about $8 \mathrm{~mm}$. thick; alveoli (as commonly) 3-verticillate in 6 lines, in young fruit about $5 \mathrm{~mm}$. distant, upper lip conspicuously thin, finally often split unevenly, lower deeply emarginate; sepals broadly oblong, $5 \mathrm{~mm}$. long, as also petals, these one-half connate, equaled by the staminodal tube, this scarcely incised, subtruncate; fruit (young) oblong, mammillate-cusped, pericarp thick; male flowers fallen.

Huánuco: Among evergreens, mostly shrubs, southwest of Monzón, 2,200 meters, (Weberbauer 3552, type).

\section{TAENIANTHERA Burret}

Reference: Burret, Bot. Jahrb. 63: 267-270. 1930.

Simulates Geonoma but the free anther cells after anthesis are porrect, being, without any angle, in a direct line with the filament, and the stigma (known) is applanate. Sepals lanceolate or narrow (female flower). Filaments connate only toward base. Spadices in known species simple or furcate, pits dense, spathes 2, narrowly vaginate, slender.-Indubitably the basic character of the species assigned by Burret to a distinct group is very real, being clearly stabilized, probably ancient; in monographic work, to emphasize the character, generic status may be preferred, but in floristic, especially when the plants concerned possess human interest, a more generally useful taxonomy, when possible, is desirable, and subgeneric rank may be more feasible. The author himself (267) remarked (trans.): I was in doubt if it would not be better to treat this as a subgenus but I have found no intermediate development of the anthers in the many species of Geonoma examined. In other words, for students whose interest prompts them to emphasize specific relationships by many generic names this is a "good" genus; others, if they have the pleasure of recognizing one of the following closely allied plants, especially when not in flower, will refer to it as Geonoma, whether in cultivation or native.

Leaves simple or laterally cleft, basally long-cuneate, nerves ascending, straight............... T. tamandua, T. macrostachys.

Leaves somewhat pinnatisected, rounded or shortly cuneate at base, nerves more spreading, curved. 


\section{Field Museum of Natural History-Botany, Vol. XIII}

Floral pits 5-7-ranked, somewhat inclined.

Leaf-segments 2-3.5 dm. $\times 3-9 \mathrm{~cm} . \ldots \ldots \ldots$. . tapajotensis.

Leaf-segments about $2 \mathrm{dm} . \times 2-5 \mathrm{~cm} . \ldots \ldots \ldots$. oligosticha.

Floral pits in 10-15 verticils or little inclined series.

Leaf-segments 3-6 pairs, upper multinerved.

Leaf-segments distant.................. acaulis.

Leaf-segments partly united..............T. Lagesiana.

Leaf-segments many, 1-nerved................ camana.

Taenian thera acaulis (Mart.) Burret, Bot. Jahrb. 63:267. 1930. Geonoma acaulis Mart. Hist. Nat. Palm. 2: 18, pls. 4, 9. 1823.

Leaves pinnate, erect or suberect, rosulately congested (with spadix) on caudex, sometimes as many as 12 , a meter long or longer including the long slender petiole, the younger fuscous-leprose; segments $3-6$, the more or less divaricate subequal lateral oblonglanceolate, (1) 2-10 cm. wide, (2) 3-4 dm. long, few- to many-nerved, the furcate terminal one much wider; peduncle about $6 \mathrm{dm}$. long; spadix striate, 6-9 dm. long, simple, cylindric; lower spathe scarcely $1 \mathrm{dm}$. long, upper 2-2.5 dm. long; spike incrassate-cylindric, 8-13 cm. long, 7-10 cm. thick, densely flowered, the deep pits 10-12-ranked, the lip emarginate; flowers $4-8 \mathrm{~mm}$. long, male corolla at least twice longer than calyx, deeply 3-parted, short or campanulate stamen tube extended into broadly liguliform filaments, the tube in female flowers urceolate, dentate.-Burret noted that the anthers were longer than shown in the otherwise good illustration by Drude (Mart. Fl. Bras. 3, pt. 2: pl. 121, fig. 1. F.M. Neg. 18501.

Peru (probably, as at Juruá Mirim, nearly on the Brazilian boundary). To Colombia; Amazonian Brazil. "Palmilla" (Dahlgren).

Taenian thera camana (Trail) Burret, Bot. Jahrb. 63:270. 1930. Geonoma camana Trail, Journ. Bot. 14: 324. 1876.

Caudex (type) 1-1.5 meters tall, 2.5-4 cm. in diameter, densely annulate, erect or flexuose; leaves pinnate, glaucous green, 1.5-2.5 meters long (petiole 6-12 dm. long, sulcate), the 17-21 (31) segments subfalcate-linear, 1-2-nerved, or lanceolate-rhombic, the upper several-nerved; spadix 4.5-6 dm. long (peduncle to about $1 \mathrm{dm}$. long), spathes 2-3 dm. long, linear-tubular, spike 1.5-2 dm. long, slender, obtuse, the densely congested spiralled pits in about 15 ranks; fruit ellipsoid, scabrous, black, $9 \mathrm{~mm}$. long, $6 \mathrm{~mm}$. thick.-Type from 
inundated areas on the Ríos Gavary and Jutabi on the Brazilian border. F.M. Neg. 38643.

Loreto (no doubt; cf. note above). Adjacent Brazil. "Juritiubim" (Trail).

Taenianthera Lagesiana (Damm.) Burret, Bot. Jahrb. 63: 268. 1930. Geonoma Lagesiana Damm. Verh. Bot. Ver. Brandenb. 48: 121. 1906.

Type 2 meters tall with ample dark green long-oval more or less 3 -pinnate leaves, the petioles at least $3.5 \mathrm{dm}$. long, the rachis about $7.5 \mathrm{dm}$. long, nerves (each side) about 35; segments $3-8 \mathrm{~cm}$. distant, to $4.5 \mathrm{dm}$. long, long-acuminate; spathe obliquely open, peduncle $4.5 \mathrm{dm}$. long or longer, stout, the 2 branches about $2.5 \mathrm{dm}$. long, densely flowered, $1 \mathrm{~cm}$. in diameter; male flowers $3.5 \mathrm{~mm}$. long, calyx lobes spathulate, ciliate, $3 \mathrm{~mm}$. long, corolla $3.5 \mathrm{~mm}$. long, lobes oblong; staminal tube short, anther cells clavate, $1.5 \mathrm{~mm}$. long.Distinct from G. acaulis Mart. by the longer leaves with partly united segments (Burret), a character that may prove variable; type, Ule 5745 from Juruá Mirim, nearly on the Peruvian boundary.

Peru (certainly). Adjacent Brazil.

Taenianthera macrostachys (Mart.) Burret, Bot. Jahrb. 63: 268. 1930. Geonoma macrostachys Mart. Hist. Nat. Palm. 2: 19, pl. 20. 1823.

Acaulescent, the thick caudex bearing 10 or more crowded simple or subsimple leaves about 1.5 to nearly $2 \mathrm{dm}$.long, the younger reddish tomentose or furfuraceous, soon glabrous, coriaceous, long-decurrent into petiole at least about $3 \mathrm{dm}$. long, triangular-lanceolate, falcate, furcate, the apical segment at least $2.5 \mathrm{dm}$. long, each part $1 \mathrm{dm}$. wide, primary nerves about 30 ; peduncles tomentose, about $8 \mathrm{dm}$. long, spadix erect, 1 meter long, upper spathe narrowly tubular, about $3 \mathrm{dm}$. long; spike 1.5-2 dm. long, 8-9 mm. thick, attenuate and mostly extended into a filiform sterile portion; pits deep, approximate, the short lip rounded, bilobate or deeply emarginate; flowers $3 \mathrm{~mm}$. long, calyx and corolla subequal, male petals free, female connate medially, staminal tube lageniform in male flower, deeply 6-dentate in female flower; fruit dark purple, lustrous, ellipsoid, 7 or $8 \mathrm{~mm}$. long, perhaps larger (Burret). Burret also observes (l.c.) that Drude's plate (for G. acaulis), not that of Martius, depicts correctly the similar stamen-character.- Since it has been collected nearly at the eastern boundary of Peru (Río Tejo, Ule) it must extend 
into Loreto or Madre de Dios; however, Burret noted (l.c.) that the record of Poeppig from Cuchero does not pertain to this palm. F.M. Negs. $18514 ; 29875$.

Loreto (no doubt; see note above). Brazil; Bolivia; Colombia.

Taenian thera oligosticha Burret, Notizbl. Bot. Gart. Berlin 11: 201. 1931.

Acaulescent, leaves small, primary nerves about 20, rachis to $2 \mathrm{dm}$. long, deciduously fuscous scurfy as peduncles, segments 4-5 pairs, concolor, narrowly long-acuminate, apical broader than the rest, about $5 \mathrm{~cm}$. wide, $2 \mathrm{dm}$. long (upper margin), primary nerves 8 , others about $2-2.5 \mathrm{~cm}$. wide, primary nerves $3-5$, little narrowed to base; secondary nerves little narrower beneath than primary, the tertiary more obvious above than below; spadix simple, slender, the peduncle much longer than the spike, this $13-17 \mathrm{~cm}$. long, nearly 6 $\mathrm{mm}$. thick (with flowers), apically (type) spinose; pits approximate, in 7 scarcely declined series, $2 \mathrm{~mm}$. distant, lower lip emarginate, upper not at all or obscurely produced but forming a very acute margin; female sepals somewhat emerging, $2.5 \mathrm{~mm}$. long, petals shorter, densely and acutely nervose, staminodal tube 6-lobed.Peduncle sometimes longer than 2 meters, petiole $6 \mathrm{dm}$. long, sheath $7 \mathrm{~cm}$. long, rachis $28 \mathrm{~cm}$. long (Klug). Near T. acaulis but series of flower groups and nerves fewer, spadix smaller (author).

Loreto: Río Nanay, Williams 737, type; 740. Mishuyacu, Klug 448.

Taenianthera tamandua (Trail) Burret, Bot. Jahrb. 63: 268. 1930. Geonoma tamandua Trail, Journ. Bot. 14: 323. 1876.

Near T. macrostachys; type with leaves 1.5-2 meters long, dark green, strongly plicate, primary nerves $25-27$ each side, nearly straight, petiole $1.5 \mathrm{dm}$. long, deeply canaliculate; spike white tomentose, 2.5-3.3 dm. long, to $11 \mathrm{~mm}$. thick, obtuse, the pits 10-11-ranked, the lower lip bifid, tomentose.-Incompletely known, but, as Burret remarks, spike definitely longer, thicker; type from non-inundated area at the Río Javary. F.M. Neg. 38665.

Peru (probably). Brazil. "Tamandua-pecu" or "-ubim" (Trail).

Taenianthera tapajotensis (Trail) Burret, Bot. Jahrb. 63: 269. 1930. Geonoma acaulis Mart. subsp. tapajotensis Trail, Journ. Bot. 14: 342. 1876. Geonoma tapajotensis (Trail) Drude in Mart. Fl. Bras. 3, pt. 2: 508. 1882. 
Habit of T. acaulis but smaller in all parts; petiole, with sheath, 4.5-5.5 dm. long; leaves scarcely 1 meter long, segments $3-4$ pairs, broadly ovate-lanceolate, long-acuminate, $2-3.5 \mathrm{dm}$. long, $3-9 \mathrm{~cm}$. wide; spadix 5-6 dm. long, spathes firm-membranous, the lower 5, the upper about $13 \mathrm{~cm}$. long; spike 5-7.5 $\mathrm{cm}$. long, 3-4 mm. thick, with a mucronate sterile extension $1 \mathrm{~cm}$. long, pits 6-7-ranked; flowers (Trail) as in T. acaulis; fruit globose, about as large as a pea but immature.-Ordinarily 3 pairs of leaf-segments, but sometimes 1 or 2 narrow segments also, both sides.

Loreto: Mouth of Río Santiago, flood-free wood, (Tessmann 4715, det. Burret). Amazonian Brazil.

\section{IRIARTEA R.\& P.}

Socratea Karst. Linnaea 28: 263. 1856. Iriartella Wendl. Bonplandia 8: 103. 1860.

Handsome palm marked by partly exposed more or less aculeate roots supporting and seemingly bracing the tall stem, this bearing a coma of long pinnate leaves with many deltoid unevenly dentate or laciniate segments (nerves prominent beneath) and 2-several spathes; flowers with both sexes in the same spadix, all the younger (corniform) or the intermediate of each three, female, spiralled. Male flowers subsymmetric, sepals orbicular, concave, broadly imbricate. Ovary 3-celled, stigma early apical or central. Fruit 1-seeded, ovoid or globose, stigma position various.-Staminodia always present (Burret). As to original species-see remarks about Socratea-stamens are 12-20, stigma terminal or subterminal, embryo sub-basal, slightly below middle of seed, raphe distinctly anastomosed; the leaves of $I$. exorrhiza are merely bifid; in Iriartella the fruit has stigma at base, embryo subterminal. Socratea is like Iriartea but, especially, stamens many (to 25), stigma in fruit (as embryo) subterminal, leaves, at least as to original species, equally pinnate, spadices solitary, spathes 4-8. Drude treated Socratea as a section (1882), later as a subgenus (1889). Bentham and Hooker (1880) wrote that Socratea, Iriartella, Dictyocaryum could all be treated as subgenera or sections. Recently Burret accepted them. The taxonomy most generally useful would be that of Drude, a conclusion reached by Spruce (Journ. Linn. Soc. 11: 133. 1871), who remarked that similar differences exist in single genera of exogens as Cordia; all these palms (Socratea, Iriartella, Iriartea) are so alike in habit that the Indians unhesitatingly give them the same generic name (Pax$i u b a)$; and a closer examination reveals so many essential resem- 
blances that the botanists will probably endorse the opinion of the Indians and continue to unite them under one title. To date, verily, this is a vain hope.

Stigmas apical or subapical; stems cylindric; fruit subglobose.

Embryo apical; stamens 20-25 .............. exorrhiza.

Embryo sub-basal; stamens (known) 15.

Flowers, fruits in 7 series ............... Weberbaueri.

Flowers, fruits in fewer series............... deltoidea. Stigmas excentric; embryo lateral.

Stems ventricose; fruit globose.................. ventricosa.

Stems cylindric; fruit oblong-linear. ............ stenocarpa.

Iriartea deltoidea R. \& P. Syst. Veg. 298. 1798. Ceroxylon deltoideum (R. \& P.) HBK. Nov. Gen. \& Sp. 1: 308. 1815.

Caudex 20 meters tall or taller; earliest leaves bifid, apical segments of adult deeply bilobed or bifid, all glabrous, size of I. exorrhiza; spadix $6 \mathrm{dm}$. long or longer, branches incrassate, excavate-scrobiculate; male calyx glabrous; spathes 10-12, deciduous; stamens 15; fruits subglobose, (stigma remains subapical), yellowish-brown, with their flesh mucilaginous (Martius), raphe branches ascending, reticulately anastomose, embryo sub-basal.-Illustrated, R. \& P. Prodr. pl. 32. 1794; Mart. Hist. Nat. Palm. 1: pl. Z5, figs. 3, 7; Weberbauer, 594, pl. 35. F.M. Negs. 18532; 18532A.

Huánuco: Pozuzo, (Ruiz \& Pavón, type).-Junín: Chanchamayo Valley, (Raimondi 2641; 10405). La Merced, (Weberbauer 1839; 1850).-Puno: San Gován, (Lechler 1725; 10405). "Huacra-pona," "camona," "morona."

Iriartea exorrhiza Mart. Hist. Nat. Palm. 2: 36, pls. 33-34. 1824; 538. Socratea exorrhiza (Mart.) Wendl. Bonplandia 7: 103. 1860 .

Tall, sometimes 20 meters or taller, cylindric but with many partly branched aerial roots at base, at least the exposed portion prickly, and crowned with a dense cluster (10-15) of oblong leaves 4-6 meters long with 15-20 pairs of deltoid or oblique-rhombic segments finally $5 \mathrm{dm}$. long, 1.5-2 dm. wide, shorter but mostly as wide toward apex, all radiately about 10-dentate (or entire); spadices 1-4 below the coma, stoutly peduncled, about $5 \mathrm{dm}$. long, the 5 or 6 spathes ventricose-inflated base to apex, before anthesis horn-like, $4 \mathrm{dm}$. long, finally caducous, branches nutant, slender, densely flow- 
ered; flowers yellowish, the larger male nearly $1 \mathrm{~cm}$. long; stamens 20-25; fruit olive-yellowish, perhaps reddish, $3 \mathrm{~cm}$. long, more than $2 \mathrm{~cm}$. thick, exocarp indurate, seed $2.5 \mathrm{~cm}$. long, $18 \mathrm{~mm}$. in diameter, reticulately rugulose-lineate, stigmatic remains scarcely discernible; embryo at depressed apex of seed, barely within the hard horny albumen; raphe of many flat filaments radiating from base to apex, subramose, anastomosing (Spruce).-By Drude (l.c.) as by Trail (Journ. Bot. 6 (15): 130. 1870) regarded as a variable species including I. exorrhiza Mart. var. elegans (Karst.) Drude (539), leafsegments about 5, incised-dentate, spathes mostly 4, fruit finally yellow, somewhat smaller, and var. Orbignyana (Orbigniana) (Mart.) Drude (540), leaf-segments many, radiately dentate, fruit orange, $2 \mathrm{~cm}$. long, scarcely $1.5 \mathrm{~cm}$. thick. Both of these have been recorded-as varieties or species-from adjacent Colombia or (and) Brazil so no doubt they occur within Peru. Trail (1.c.) observed "a complete transition" between I. exorrhiza and I. Orbignyana but fide Martius the seed of the latter is only a third as large. The curious roots that support or brace the beautiful stems near the base are illustrated by Drude in Pflanzenfam. 2, 6: 14, and the flowers and fruit in Mart. Fl. Bras. 3, pt. 2: pl. 126. F.M. Neg. 18533.

San Martín: Tocache, (Poeppig, fide Drude). Colombia; Brazil to Guianas. "Huacra," "huacra-pona."

Iriartea stenocarpa (Burret) Macbr., comb. nov. Iriartella stenocarpa Burret, Notizbl. Bot. Gart. Berlin 11: 233. 1931.

Type 3 meters tall, slender, the sheath (apical part seen) hirsute velutinous, the longer trichomes yellowish, retrorse, the shorter whitish, dense; petioles about $2.5 \mathrm{dm}$. long (probably longer), terete but sulcate-costate, rather closely and retrorsely white-pubescent, the rachis densely so with short and long trichomes; segments rhombiccuneiform, decurrent at base 6-6.5 cm., free $15-16.5 \mathrm{~cm}$., pubescent as midrib above, more or less glabrescent, conspicuously soft beneath; immature fruiting spadix $36 \mathrm{~cm}$. long; peduncle $29 \mathrm{~cm}$. long; spathes 4 , laxly vaginate, shortly and softly pubescent, nearly attaining the lower branches; rachis $2.5 \mathrm{~cm}$. long; branches 4-6, simple, curved, glabrate, $21 \mathrm{~cm}$. long; fruit laxly spiralled, linear, curved, 10-11 $\mathrm{mm}$. long, $3 \mathrm{~mm}$. thick (young); perianth cupulate, somewhat enclosing fruit-base, $2 \mathrm{~mm}$. high, $3.5 \mathrm{~mm}$. across; sepals erect, broadly rounded as the twice as long petals.-Distinct from I. setigera Mart. by the larger perianth and the very slender fruit (author); the Martius' species probably occurs on the upper branches of Río Japurá 
within Peru; the exposed roots are sparsely muricate, the slender stem 2-3 meters high and prominently tomentose-setose above, the leaves tomentulose beneath, the apical segments entire, the lateral erose-dentate.

Loreto: Ríos Napo and Amazonas, (Hopp 110, type).

Iriartea ventricosa Mart. Hist. Nat. Palm. 2: 37, pls. 35, 36. $1824 ; 537$.

Caudex 20-35 meters, ventricose medially or lower, annulate above at intervals of 2-3 dm.; roots sparsely aculeate, at least about 2 meters high; leaves usually 7 or fewer, to $6 \mathrm{~mm}$. long, petioles subterete, $1 \mathrm{dm}$. across, sheath scarcely $3 \mathrm{dm}$. long; rachis acutely trigonous, grayish tomentose; pinnae many, cuneate-flabellate, soon glabrate, veins and plicae 10, finally splitting nearly to base, the lower laciniae much longer and wider (nearly 2 meters long), the upper gradually reduced to hardly $6 \mathrm{dm}$. long, all laciniae apically broadly sinuate-dentate and erose; spadices often binate from the same annulus, about $5 \mathrm{dm}$. long, spreading or subpendulous in fruit; peduncle $7 \mathrm{~cm}$. long, abruptly dilated at base; branches at most 3 $\mathrm{dm}$. long, $8 \mathrm{~mm}$. thick, simple or furcate at base, deeply alveolate entire length, spathes many, upper before anthesis, lower tardily deciduous; stamens 12-15; fruit globose, minutely umbonate; stigmas on fruit clearly excentric; embryo lateral just above middle of seed, this with fragile testa, filaments of raphe clearly anastomose.-In part after Spruce, who noted it as frequent between 700 and 1,200 meters in the eastern Andean valleys, along with $I$. exorrhiza Mart. and I. deltoidea R. \& P. F.M. Neg. 13535.

San Martín: Tarapoto, (Spruce),-Loreto: Yurimaguas, (Poeppig). "Tarapoto" (Spruce), "huacra-pona," "conduma." Amazonian Brazil.

Iriartea Weberbaueri Burret, Notizbl. Bot. Gart. Berlin 10: 921. 1930 .

Fragment of rachis (probably upper portion) broadly triangular, laterally widely excavated, dorsally nearly plane, opaque, obscurely but densely and minutely setulose; segments (apical) about $5 \mathrm{dm}$. long, cuneate, yellowish; sheath strongly puncticulate, dark brown within, heavy-ligneous; fruiting spadix pendent, in entirety nearly 2 meters long; peduncle $3.5 \mathrm{dm}$. long, $4 \mathrm{~cm}$. thick at apex, terete, scars 12 , approximate at base, remotely annulate above, the ultimate toward apex three-fourths encircling the peduncle; primary branches 
crowded, 27, the lower 9 furcate, the rest simple, the basal coarsely callose within, the upper applanate-rounded; branchlets as seen about $9 \mathrm{dm}$. long, below $8 \mathrm{~mm}$. thick, flowers (per scars) ternate, 2 male; alveoli $5 \mathrm{~mm}$. long, $2.75 \mathrm{~mm}$. broad, in 7 vertical series, equally distant $1.5 \mathrm{~cm}$.; fruit (known) globose, $2.8 \mathrm{~mm}$. in diameter, scarcely excentric at minutely mammillate apex, lustrous, light yellowishbrown; perianth (in fruit) to $1.5 \mathrm{~cm}$. across; pericarp fleshy squamose within; seed about $1.5 \mathrm{~cm}$. in diameter.-Distinguished from $I$. deltoidea R. \& P. by the much larger fruits, thicker spadix rachis, the flowers and fruits in more series; from $I$. stenocarpa Mart. similarly by the size of fruit, further by the cylindric stem (author).

Puno: Chunchusmayo, Prov. Sandía, (Weberbauer 1279, type). "Morona."

\section{Catoblastus Wendl.}

Acrostigma Cook \& Doyle, Contr. U. S. Nat. Herb. 16: 228. 1913. Catostigma Cook \& Doyle, l.c. 230.

Reference: Burret, Notizbl. Bot. Gart. Berlin 10: 932. 1930.

Aerial roots short, stem slender. Flowers remote, all male or female in each simple or simply branched spadix; spathes 5 or more, the upper longer. Petals free or basally imbricate. Stigma rostrate, borne on a columnar style or sessile at the base of the single fertile carpel (Catostigma). Stamens 9-15, staminodes none or filiform.Taxonomically significant as evidence of relationship, it would be more useful to treat the floristic character of Catostigma as sectional in definition; the differences in development, too, may be tenuous or merely specific; for instance, Acrostigma was based primarily on having 3 equal carpels at anthesis, while Catostigma shares with Catoblastus the diagnostic character of a single enlarged carpel at anthesis. Spadices often several from the same leaf annulus. The group (sens. lat.), in view of the variation in distribution of male and female flowers, could be referred to Iriartea as a subgenus.

Catoblastus Drudei Cook \& Doyle, Contr. U. S. Nat. Herb. 16: 233, fig. 41. 1913. Iriartea pubescens Karst. var. krinocarpa Trail, Journ. Bot. 5 (15): 332. 1876. C. pubescens (Karst.) Wendl. Bonplandia 8: 104. 1860, var. krinocarpa Trail ex Drude in Mart. Fl. Bras. 3, pt. 2: 543, pl. 127, fig. 2. 1882, not C. pubescens Drude, Pflanzenfam. 2, Abt. 3: fig. 48, G1, G2. 1887, nor Wendland, fide Cook \& Doyle. Catostigma Drudei (Cook \& Doyle) Burret, Notizbl. Bot. Gart. Berlin 10: 932. 1930. 
Caudex 3-5 meters tall, 2-3.5 cm. in diameter; leaves pubescent below, 13-15 dm. long (sheath puberulent-tomentose, 3-5 dm. long), segments oblanceolate, $10-11$ pairs, basal $1.75 \mathrm{dm}$. long, nearly $2 \mathrm{~cm}$. wide, medial 3-4 dm. long, 5-7 cm. wide, apical deltoid (connate), $2 \mathrm{dm}$. long, $12 \mathrm{~cm}$. wide; spadices $3-5$ from one axis with 5 simple caudate branches to $5 \mathrm{~cm}$. long, nutant, in fruit pendulous; female flowers about $5 \mathrm{~mm}$. long, the tumid fertile ovary equaled by the ovate-acute petals, the sterile thick gibbous style little longer; sterile anthers (or anther) present, mucronate; fruit about $2 \mathrm{~cm}$. long, $12 \mathrm{~cm}$. in diameter, stellate puberulent, style rudiment persisting.Habit of $I$. setigera Mart. (see under $I$. ventricosa); when not in flower most readily distinguished by the narrower usually more numerous pinnae, pubescent below.

This is a species quite different from Iriartea pubescens Karst. of Colombia as beautifully illustrated by Karsten (Pl. Col. 1, pl. 81); type locality, Río Yavari on the boundary with Brazil, on noninundated terrain.

Loreto (no doubt). Amazonian Brazil. "Ponilla."

\section{WETtiniA Poepp.}

Wettinella Cook \& Doyle, Contr. U. S. Nat. Herb. 16: 235. 1913, fide Burret.

Reference: Burret, Notizbl. Bot. Gart. Berlin 10: 939-942. 1930.

Aspect of Iriartea but as in Catoblastus the flowers of one sex in a spadix, this short, club-like so compactly clothed with the pubescent fruits. Petals of male flowers subulate, free. Fertile ovary 1 , often with 1 or 2 sterile, the much longer style from the base with elongate stigmas. Embryo basal. Spadices simple (8-15 for each node) or 4-5-branched, 4 of the 5 inforescences maturing (Wettinella), this subgroup also with sepals broader than petals (authors). The pollen tuberculate, not smooth, as, by error, in lit. (Burret).

Leaf-segments about 20 pairs.

Stamens about half as long as petals, sepals (female) at most half as long . . . . . . . . augusta.

Stamens at least as long as petals, sepals (female) at least a third as long. .......................Weberbaueri. Leaf-segments about 40 pairs. ..............W. maynensis.

Wettinia augusta Poepp. \& Endl. Nov. Gen. \& Sp. 2: 39, pls. 153, 154. 1838; 939. 
Similar to $W$. maynensis, aerial roots interposed; leaf-pinnae 18-20 pairs; spathes several, yellowish pilosulous; spadices simple, 8-15, verticillate; stamens about half as long as petals; sepals of female flowers a third to half as long as petals; style and 3 stigmas rather slender; raphe fleshy.-The finally incomplete spathes remain on peduncle as coriaceous sheaths. Kunth (Enum. Pl. 3: 109. 1841) proposed the species name Poeppigii, perhaps not aware that the author of the genus (published in 1836) had added the species later. Illustrated, Contr. U. S. Nat. Herb. 16. pl. 63. F.M. Neg. 29887.

San Martín: Tocache, (Poeppig 2058, type).

Wettinia maynensis Spruce, Journ. Linn. Soc. 3: 194. 1859. Catoblastus maynensis (Spruce) Drude in Mart. Fl. Bras. 3, pt. 2: 544. 1882. Wettinella maynensis (Spruce) Cook \& Doyle, Contr. U. S. Nat. Herb. 16: 235. 1913.

Aerial roots strict, subaculeate; stem to 12 meters tall, 3-4 dm. in diameter, smooth, annulate; leaves 5 or $6,4 \mathrm{~mm}$. long, equally pinnate, pinnae 38-40 pairs, the lowest reduced, the medial 1 meter long, $7.5 \mathrm{~cm}$. wide, finally incised, veins many, nearly contiguous at semivertical reduplicate base; spadices 3 (6) in each verticil, 1 female, 2 male, mature fruit usually on fourth ring below the leaves; spathes 6 , fusiform, appressed pubescent, the incomplete outer $1 \mathrm{dm}$. long, the 3 complete about 3 times longer; male branches $6,1.5 \mathrm{dm}$. long, densely flowered and straight, in anthesis sepals scale-like, rigid, castaneous, free; petals $14 \mathrm{~mm}$. long, subulate; stamens 13 (12-16); female branches 5-7, crowded, $2 \mathrm{dm}$. long, in fruit about half as thick, sepals 4-6 mm. long, petals 10-12 mm. long; ovaries 3, united and with style, this central, $14 \mathrm{~mm}$. long, villous, the abortive ovaries rarely deciduous; stigmas erect, $6 \mathrm{~mm}$. long; fruit dry, gray villous, endocarp membranous, seed $22 \mathrm{~mm}$. long, half as thick, albumen uniform.-Not infrequent both north and south of the Río Mayo, 1,000-1,500 meters, associated with Euterpe and Iriartea ventricosa according to Spruce, who, l.c. 190 (by lapsus, as shown in index) wrote "W. illaqueans."

San Martín: Tarapoto to Moyobamba, (Spruce, type). Ecuador. "Shulla-chonta," "pullo-coroto," "cullo-coroto."

Wettinia Weberbaueri Burret, Notizbl. Bot. Gart. Berlin 10: 939. 1930.

Original tree 10 meters tall, petioles apparently subterete and $1.5 \mathrm{dm}$. long; rachis triangled above, furfuraceous, segments seen 
disposed regularly, narrow, maximum seen $5.4 \mathrm{dm}$. long, upper somewhat reduced, strongly drawn together at base, subconcolor both sides; male spadix to upper spathe tip $23 \mathrm{~cm}$. long, inner spathes finally laciniate, mostly several $\mathrm{cm}$. long, $1.5-3 \mathrm{~cm}$. wide, fourth and fifth early complete, thickly inflated-fusiform, tardily split; peduncle shortly ferrugineous, velvety, finally annulate by the rudiments of the spathes, these early reddish sericeous strigillose; spadix fusiform, in flower $7 \mathrm{~mm}$. thick at base, attenuate, the male flowers approximate, $1 \mathrm{~cm}$. long; sepals as petals linear, the former 1 , the latter 8-9 $\mathrm{mm}$. long, acuminate, the 12 stamens at least as long; female spadix similar; sepals 6-10 $\mathrm{mm}$. long, 4-5 mm. broad at base, acute, petals to a third longer; fertile carpel yellowish villous; stigmas at least $5 \mathrm{~mm}$. long, $1.75 \mathrm{~mm}$. thick.-Differs from $W$. augusta Poepp. \& Endl. in subequal stamens and petals, stouter stigmas, probably also in reddish indument and leaves (author).

Puno: Prov. Sandía, Chunchusmayo, 900 meters, (Weberbauer, no number, type).

\section{GEROXYLON Humb. \& Bonpl.}

Reference: Burret, Notizbl. Bot. Gart. Berlin 10: 841-854. 1929.

Tall, slender or robust, the columnar stem more or less waxwhitened, annulate, crowned with many multipinnate leaves their rigid fleshy or coriaceous segments ensiform, and at their nodes elongate, much-branched spadices, the polygamous or monoecious flowers on different branches. Spathes 3 or more, the upper complete, coriaceous. Pedicels short, often arcuate or bent. Calyx minute, petals ovate- or subulate-lanceolate, acuminate, more or less adnate; male flowers with 9-15 stamens; female with 9-12 staminodes, 1 sterile stamen. Fruit with 1 or 3 fertile cells, residual style at base, pericarp smooth or granulate; seed erect, raphe ascending from base, branched reticulate, albumen uniform.-Seedlings develop rootstocks.

The type species is the Colombian $C$. andicola HBK., the most famous wax palm of the Andes. The fruit of $C$. Schultzii Burret of Colombia, as probably that of other palms, is sought by parrots (Arnold Schultze).

\section{KEY (after Burret)}

Calyx teeth at least half as long as corolla tube; leaf-segments regularly disposed.

Spadix large, robustly 3-much-branched......... C. latisectum. Spadix small, the branches most simple........ Weberbaueri. 
Calyx teeth minute, many times shorter than corolla; leaf-segments aggregate.

Leaves to $6 \mathrm{dm}$. long; branched part of spadix $2.5 \mathrm{dm}$. long.

C. crispum.

Leaves 2 meters long; spadix ample............. verruculosum. 1929.

Geroxylon crispum Burret, Notizbl. Bot. Gart. Berlin 10: 849 .

A small species with, in general, about the same characteristics and measurements (except the floral) as $C$. verruculosum except as follows: petioles 2-2.5 dm. long, $1 \mathrm{~cm}$. wide at apex, nearly plane above, convex beneath; segments 40-50, mostly 2-3-aggregate, crisped (direction various), lowest 15-18 $\mathrm{cm}$. long, apical about 12 $\mathrm{cm}$. long, maximal medial $21 \mathrm{~cm}$. long, little wider than $1.5 \mathrm{~cm}$., all attenuate to oblique apex, very rigid, the midnerve above and surface beneath furfuraceous; peduncle spathes 5 , lower $3 \mathrm{~cm}$. broad; branches about 30 , branchlets 10 , early sparsely furfuraceous; young fruits densely, distinctly verruculose; calyx tube $0.5 \mathrm{~mm}$. long, teeth minute, obscure; corolla tube at least $1.5 \mathrm{~mm}$. long, teeth acuminate, striate, $3(-4) \mathrm{mm}$. long.- These palms, together with Geonoma megalospatha Burret, grow at the highest boundary for Peruvian species (Burret).

Huánuco: Chinchao, Acomayo, 2,800-2,850 meters, (Weberbauer 6825 , type).

Ceroxylon latisectum Burret, Notizbl. Bot. Gart. Berlin 10: 844. 1929.

Trunk known to attain 11 or 12 meters, $2.5 \mathrm{dm}$. in diameter a meter above the terrain, petioles $8 \mathrm{dm}$.; leaves 1.75 meters, the segments disposed evenly in one plane; rachis of apical part of leaf acute above, plane or nearly beneath, fuscous furfuraceous as the segments finely beneath, all yellowish-green above, the latter at apex $13 \mathrm{~cm}$. long, $1 \mathrm{~cm}$. wide, $24 \mathrm{~cm}$. below, about $4 \mathrm{~cm}$. wide, those of the upper third subequal, broader, abruptly contracted, the basal more approximate, $3.3 \mathrm{dm}$. long, nearly $5 \mathrm{~mm}$. wide; peduncle stout, $13 \mathrm{dm}$. long, branched part $7.5 \mathrm{dm}$. long, the divaricate branches 3-many times branched; spathes many, lowest ligneous, applanate, at base $8.5 \mathrm{~cm}$. broad, $2.5 \mathrm{dm}$. above the base $10.5 \mathrm{~cm}$. broad; lowest primary branches nearly $4 \mathrm{dm}$. long, $5 \mathrm{~cm}$. pedunculate, intermediate branches shorter, slenderer, flexuose; fruit globose, smooth, $2 \mathrm{~cm}$. in diameter without perianth; calyx teeth and tube each $0.75 \mathrm{~mm}$. long, 
equaling corolla tube, its lanceolate acuminate teeth about $3 \mathrm{~mm}$. long; seed globose, $13 \mathrm{~mm}$. in diameter.-Fruit at maturity fiery red (collector). Illustrated, Weberbauer, page 504, pl. 19.

Amazonas: Congon to Conila, 2,950 meters, (Weberbauer 1161, type).

Ceroxylon verruculosum Burret, Notizbl. Bot. Gart. Berlin 10: 850. 1929.

Trunk 7 meters tall, $2 \mathrm{dm}$. in diameter, smooth, green but thinly waxed; sheaths $12 \mathrm{dm}$. long, petioles $5 \mathrm{dm}$. long, leaves 2 meters long, the segments aggregate, yellowish-green above, very finely white furfuraceous beneath as the spathes and spadix-rachis, the former compressed basally, $8.5 \mathrm{~cm}$. broad, at least $18 \mathrm{~cm}$. long, probably longer; peduncle long, stout, transversely oval, spathes many; branches divaricate, twice branched, the primary nearly $5 \mathrm{dm}$. long, the many slender branchlets flexuose, the rachis at base $2 \mathrm{~cm}$. thick; fruits laxly spiralled, globose, without perianth $1.8 \mathrm{~cm}$. in diameter, minutely but distinctly and densely verruculose; perianth (in fruit) with low calyx, the teeth obscure, the corolla tube cylindric, $2 \mathrm{~mm}$. high, teeth acutely acuminate, $4 \mathrm{~mm}$. long; pericarp thin, one third $\mathrm{mm}$. thick; seed globose, $12 \mathrm{~mm}$. in diameter.--Some leaves have segments only about $1 \mathrm{~cm}$. wide, others, larger, one with terminal, regularly disposed segments; some segments $38 \mathrm{~cm}$. long are $2.5 \mathrm{~cm}$. wide; there are also color differences and some segments, nearly $7 \mathrm{dm}$. long, $3.5 \mathrm{~cm}$. wide, are bidentate and in groups of 2 or 3 (author); these are all probably normal variations and belong to the species.

Junín: Huacapistana, 2,700 meters, (Weberbauer 2284, type).

Ceroxylon Weberbaueri Burret, Notizbl. Bot. Gart. Berlin 10: 848. 1929.

Type 5 meters high; sheaths lacerate, the short petioles canaliculate above, thin-margined, $1.5 \mathrm{~cm}$. broad at apex; rachis margins excavated, acute above, pale furfuraceous beneath as segments, these rather subevenly disposed, the lower very narrow, shorter, the apical $2 \mathrm{dm}$. long, about $1 \mathrm{~cm}$. wide, the medial $5 \mathrm{dm}$. long, $8 \mathrm{~mm}$. wide; spadix $11 \mathrm{dm}$. long, branched part $2.7 \mathrm{dm}$. long, visible spathes 4 , the lower dilated at base, ligneous, the upper thin; peduncles compressed above to $7 \mathrm{~mm}$. broad at apex; branches $40-50$, only the lower sparsely branched, all glabrous; fruit obovoid, with perianth at least $13 \mathrm{~mm}$. long, $10 \mathrm{~mm}$. thick, glabrous, rugose but not all verruculose; calyx cylindric, tube $0.5 \mathrm{~mm}$. long with the small teeth to one-half 
as long or subequaling corolla tube, this with triangular or subacuminate petals.

Puno: Prov. Sandía, Yuncacoya, 1,800 meters, (Weberbauer 1157, type).

\section{WENDLANDIELLA Damm.}

Sheath cylindric, obliquely open, leaves simple or paripinnate, petiole triangular, pinnae 2-3 each side, lower subopposite, the upper 4-, remaining 3-nerved. Inflorescence subdigitate, interfoliaceous, spathes 2, cylindric, obliquely open, nearly covering peduncle, branches filiform, densely flowered. Calyx of female flowers 3-fid, the orbicular lobes gibbous as the similar corolla segments, these twice as large. Staminodes 3, minute, subulate. Ovary sessile, subglobose, 3-celled, stigmas $3(-4)$-reflexed, 1-2 cells sterile, 1 pendulous ovule in each cell.-Probably related to Chamaeodorea Willd. but distinctive in flower segments and branched inflorescence (author); flowers glomerulate in long series (Burret).

Honors worthily the Director of the Garden at Herrenhausen, Hannover, great admirer and student of palms.

Leaves simple........................W. simplicifrons.

Leaves pinnate.

Segments 2 each side...................W. polyclada.

Segments $3-4$ each side.................... gracilis.

Wendlandiella gracilis Damm. Bot. Jahrb. 36: Beibl. 80: 32. 1905.

Stem (type) only $4 \mathrm{~cm}$. thick, to 1.5 meters tall, leaves remote, sheath $5 \mathrm{~cm}$. long, petiole to $6 \mathrm{~cm}$. long, lower pinnae $16-17 \mathrm{~cm}$. long, $1.6 \mathrm{~cm}$. wide, the medial $18 \mathrm{~cm}$. long, $2 \mathrm{~cm}$. wide, the uppermost 2 $\mathrm{dm}$. long, 2.5-3 cm. broad, elongate-obovate-lanceolate; lower spathe $8 \mathrm{~cm}$. long, upper tubular, peduncle canaliculate above, $13 \mathrm{~cm}$. long, apically ventricose, subdigitate, the crowded flowers scarcely $1 \mathrm{~mm}$. across; male calyx as corolla lobes 3 , connate at base; stamens 6 , anthers affixed dorsally, introrse; stigmas 3 ; fruit orange-red, oval, $8 \mathrm{~mm}$. long, nearly $6 \mathrm{~mm}$. thick, pericarp thin, fibers none, the 2 larger raphe branches 3-furcate, calyx (fruiting) $1.5 \mathrm{~mm}$. across, lobes broadly rounded, petals ovate; basal sterile carpels 2 ; stigmas small.-Description of male flowers and fruits after Burret from Williams and Killip and Smith specimens. 
Loreto: Huimbaio, Pampa de Sacramento, between Río Ucayali and Rio Huallaga, (Huber 1541, type). Lower Huallaga, Williams 4566. Puerto Arturo, (Killip \& Smith 27775).

Wendlandiella polyclada Burret, Notizbl. Bot. Gart. Berlin 11: 203. 1931.

Caespitose, dioecious, the stem of type $12 \mathrm{dm}$. high, $5 \mathrm{~cm}$. in diameter, the leaves about 6 ; sheath green, even the margins, efibrose, obliquely truncate, glabrous, long-striate; petioles $14 \mathrm{~cm}$. long, rachis 4-8 cm. long, segments 2 pairs, concolor, thin-membranous, narrowly acuminate, the larger lower leaves $27 \mathrm{~cm}$. long, 7-8 $\mathrm{mm}$. wide at base, widening to $3 \mathrm{~cm}$., acuminate, the apical about $3 \mathrm{dm}$. long, at least $1.5 \mathrm{~cm}$. wide at base, $4.5-5 \mathrm{~cm}$. at upper third; spadix above sheath $3 \mathrm{dm}$. long, duplicate-branched; visible spathes 2 , largely covering peduncle, little dilated; branches 4 , these with 4 attenuate branchlets $4.5-9 \mathrm{~cm}$. long; male flowers in about 3 vertical series, above often 2 , at most $3 \mathrm{~mm}$. across; calyx nearly $1.5 \mathrm{~mm}$. across, the 3 lobes suborbicular; filaments connate at dilated base; pistil with 3 stigmas; fruits solitary, spiralled, oblong (juvenile); stigmas elongate, sulcate above, at base of fruit the sterile cells 2; calyx fleshy in fruit, lobes rounded, corolla larger, lobes lacerate.-Fruiting spadix (same collection) detached.

Loreto: Río Itaya, Soledad, (Tessmann 5240, type).

Wendlandiella simplicifrons Burret, Notizbl. Bot. Gart. Berlin 11: 316. 1932 .

Arundinaceous, 2-3 meters tall, unique at least in Peru by the simple leaves, these glabrous (as densely striate, obliquely truncate unevenly dentate sheath), nearly $4 \mathrm{dm}$. long (petioles 7-8.5 cm. long), thin, dark green, subconcolor, not at all produced at base, shortly acute, about $14 \mathrm{~cm}$. wide at the bifurcation; rachis $17 \mathrm{~cm}$. long, lobes $23 \mathrm{~cm}$. long, inner margin nearly direct, outer curved to apex, obscurely, remotely appressed denticulate; spadix solitary from leafsheath, in fruit $29 \mathrm{~cm}$. long, simply branched; peduncle $21 \mathrm{~cm}$. long, robust, without trace of spathes, medially $4 \mathrm{~mm}$. thick; rachis $6 \mathrm{~cm}$. long, branches 7, spiralled, upper spreading, lower reflexed, to 5.5 $\mathrm{cm}$. long, acute; flowers vertically disposed; fruit red, suboval, $1 \mathrm{~cm}$. long, $6 \mathrm{~mm}$. broad, fleshy, obtusely rounded, subacute at base, finely rugulose, efibrous; calyx (fruit) $1.5 \mathrm{~mm}$. across, obscurely lobed, stigmata basal, seed obovoid-oblong, $8.5 \mathrm{~mm}$. long, $5.5 \mathrm{~mm}$. thick; 
raphe branches 3 or 4, bifurcately few-branched; embryo mediallateral.

Junín: Puerto Bermudez, (Killip \& Smith 26515, type).

\section{GHAMAEODOREA Willd.}

Nunnezharia R. \& P. Prodr. 137. pl. 31. 1794.

Reference: Burret, Notizbl. Bot. Gart. Berlin 11: 724-767. 1933.

Stems solitary or several, slender, annulate, the leaves simple and bifid or variously pinnatisect. Sheath tubular. Spadices in or below the leaves, simple or branched; spathes 3 or more, enclosing peduncle, cleft, more or less persistent. Bracts, bractlets none. Flowers dioecious, sometimes more or less immersed; calyx cupulate, entire, 3lobed or -parted, petals free to somewhat connate, valvate or (female flower) sometimes imbricate; stamens 6, anthers included. Ovary 3 -celled, stigmas minute, recurved, ovules solitary, basal, erect. Staminodes sometimes lacking. Fruit of 1 (2-3) globose or oblong carpels, stigmas basal, pericarp coriaceous or fleshy, scarcely fibrous; raphe branches obscure, endosperm cartilaginous, uniform.-The dioecious flowers and absence of scars after they (as fruit) have fallen apparently mark the group, sens. lat. Name conserved; Kuntze's transfer (Rev. Gen. 2: 729-730. 1891) of names, including Morenia species, to the earlier cognomen of Ruiz and Pavón, "corrected" by him to Nunnezharoa as after Nuñez de Haró, Archbishop of Mexico, being without further interest is not listed.

The small flowers of $C$. fragrans (R. \& P.) Mart. ("sangapilla") exhale a wonderful fragrance which spreads a long distance in the montaña (Ruiz and Pavón); for this it is cultivated (Weberbauer). The shoots, called palmitos, and spadices as in similar groups are eaten cooked or in salads and may be excellent. Sap of ripe fruits is highly irritating.

Flowers not or little immersed; fruits on slight not deep depressions; perianth usually ecostate.

Leaves 6-multi-pinnate.

Leaf segments many pairs, $1-2.5 \mathrm{~cm}$. wide.

Lateral segments 1-nerved .............. angustisecta.

Lateral segments 2-3-nerved................. pauciflora.

Leaf segments $6-8$ pairs, $7 \mathrm{~cm}$. wide........... boliviensis.

Leaves simple or segments 2 , rarely 5 . 
Leaves often with 2 segments............. integrifolia.

Leaves merely deeply bifid........... Pavoniana, C. fragrans. Flowers (unless $C$. depauperata) well-sunken, as fruit; perianth, at least female, costate.

Leaves pinnate.

Segments 2-3 pairs.

Male calyx $1 \mathrm{~mm}$. long, $3 \mathrm{~mm}$. across ......C. depauperata. Male calyx minute, annulate.............. . lanceolata. Segments about 6 pairs.................... Herrerae. Leaves subsimple, deeply bifid................ geonomoides.

Chamaeodorea angustisecta Burret, Notizbl. Bot. Gart. Berlin 11: 318. 1932.

Caudex 1 meter high, $2.5 \mathrm{~cm}$. in diameter, internodes $5 \mathrm{~mm}$. long; sheath glabrous, long-costate-striate; petioles robust, 1 meter long; leaves 1.5 meter long, segments many, evenly disposed, all except the apical 1-nerved, narrowly linear, somewhat falcate, narrowly acuminate, concolor, thin, the apical 2-3 times wider (almost $2 \mathrm{~cm}$.), the primary nerves $2-3$, maximum seen $2.5 \mathrm{~cm}$. wide, $3.5 \mathrm{dm}$. long, the smaller nerves few, very fine, conspicuous both sides; male spadix $8 \mathrm{dm}$. long; peduncle nearly enclosed in spathes, these 6 , diameter of sheath but 4-7 $\mathrm{mm}$. in diameter, upper the longest; branches about 12 , simple, to $1.5 \mathrm{dm}$. long, slender; male flowers solitary, laxly spiralled, calyx high-cupulate, the 3 lobes enervose as the valvate petals; stamens 6; fruiting spadix orange-red; $6 \mathrm{dm}$. long, pendent, peduncle $4 \mathrm{dm}$. long, spathe scars 8 , lower approximate, rachis $1 \mathrm{dm}$. long, branches to 15 , porrect, 1-1.5 dm. long, fruits solitary, laxly disposed (perianth $4 \mathrm{~mm}$. across), oblong, black, fleshy, $16 \mathrm{~mm}$. long, half as broad, epicarp and mesocarp fragile, endocarp fibers rather firm in one plane.-Leaves resemble those of Morenia linearis R. \& P.

Junín: Colonia Perené, (Killip \& Smith 25091, type; also 24926; 25103).-Ayacucho: Kimpitiriki, (Killip \& Smith 22864).

Chamaeodorea boliviensis Damm. Notizbl. Bot. Gart. Berlin 6: 262. 1915; 756.

Slender trunk nearly $1 \mathrm{~cm}$. in diameter, sheaths cylindric, petioles 9-12 cm. long, leaf-rachis $4 \mathrm{dm}$. long, 2-3 mm. thick, segments remote, 6-8 pairs, the apical confluent, the lateral sigmoid, attenuate to base, long-acuminate, about $2.5 \mathrm{dm}$. long, 7-7.5 $\mathrm{cm}$. wide, primary nerves 5 , secondary binate between two of these; peduncle of female 
spadix at least $3.5 \mathrm{dm}$. long, 3-5 mm. thick, closely bracted, these cylindric, apically 4-7-branched, the branches densely floriferous nearly to base, $13-16 \mathrm{~cm}$. long; fruit oblong, black, $7 \mathrm{~mm}$. long, $5 \mathrm{~mm}$. thick; embryo slightly supramedial.-Somewhat resembles $C$. lanceolata (R. \& P.) Kunth with fewer leaf-segments, subequally nerved, merely acuminate, the petiole and rachis stouter (author). Type from Alto Río Acre, vicinity of Lojija, (Ule 115b), near boundary.

Madre de Dios (surely). Adjacent Bolivia.

Chamaeodorea depaupera ta Damm. Notizbl. Bot. Gart. Berlin 6: 263.1915 .

Type at most a meter tall, petioles $1.5 \mathrm{dm}$. long, rachis slender, nearly $3 \mathrm{dm}$. long, lateral segments remote, subopposite, 2-3 each side, lanceolate-falcate, long-acuminate, 2-2.5 dm. long, 22-33 mm. wide, primary nerves $4-5$, the secondary as many, apical segments broadly elongate-lanceolate, at base 11, at middle $6 \mathrm{~cm}$. wide, $32 \mathrm{~cm}$. long, primary nerves $8-9$, secondary as many; male peduncle bracted to apex, the 7 slender orange branches $17-20 \mathrm{~cm}$. long, the rather densely disposed flowers a little immersed; sepals $3,1 \mathrm{~mm}$. long, $3 \mathrm{~mm}$. broad, rounded as the 3 petals, these $2 \mathrm{~mm}$. long and broad; female flowers unknown.-The label data, Alto Acre, São Francisco, (Ule 9155b), may be incorrect (author); if not, the locality is at the Brazilian boundary.

Madre de Dios (probably). Adjacent Brazil or Bolivia.

Chamaeodorea fragrans (R. \& P.) Mart. Hist. Nat. Palm. 2: 4, pl. 3, figs. 1, 2. 1849; 730. Nunnezharia fragrans R. \& P. Syst. Veg. 1: 294. 1798.

Stems scarcely $1.5 \mathrm{~cm}$. thick, flexuose, inclined, rarely erect; leaves at most 6, glabrous, simple, deeply bifurcate, the divisions $3.5 \mathrm{dm}$. long, not over $3.5 \mathrm{~cm}$. wide, linear-rhombic, outer margin apically crenate-incised, nerves 12 each side, acute; spadices somewhat pendulous, solitary, 2-4 dm. long, very slender, the usually $2-6$ branches about $2 \mathrm{dm}$. long; spathes 3 , membranous; calyx trifid; corolla $3 \mathrm{~mm}$. long, fleshy, female 3-parted; 2 aborted ovaries indurate at base of fertile; anthers adnate below; fruit black, lustrous, $12 \mathrm{~mm}$. long, mesocarp insipid, seed black, raphe laxly reticulate (Spruce).-Forms large beds under the tall trees and perfumes the forest far and wide with its orange-colored male flowers, especially in August (Spruce). Illustrated, Oerst. L'Amer. Central 14. pl. 5, figs. 18-20.' F.M. Neg. 18539. 
San Martín: Tarapoto, 600-1,000 meters, (Spruce 65). Río Mayo, Moyobamba, (Weberbauer 4554; 585).-Huánuco: Pozuzo, Cuchero, (Ruiz \& Pavón, type).-Loreto: Shapaya on the Huallaga, (Ule 6850). Bolivia. "Chutasllium" (Ruiz \& Pavón), "sangapilla" (Spruce).

Chamaeodorea geonomoides (Spruce) Drude in Mart. Fl. Bras. 3, pt. 2: 531. 1882; 757. Nunnezharia geonomoides Spruce, Journ. Linn. Soc. 11: 122. 1871.

A meter or two tall with extremely slender, glabrous stem; petioles long-sheathed; leaves cuneate-obovate, deeply bifid, the furcate portions subfalcate, scarcely acuminate; veins 10 pairs; spadices nearly $5 \mathrm{dm}$. long, simply branched; peduncles arcuate-pendulous, $2.5 \mathrm{dm}$. long; branches slender, flexuose, about $3 \mathrm{dm}$. long, alveolate, the 1-flowered pits oblong-cymbiform, more or less remote; spathes 2 , longer than peduncle at anthesis, narrowly fusiform before opening, finally fibrous, deciduous; calyx semi-immersed, shortly 3-lobate, transversely rugulose, lowest lobe slightly higher, persisting, the 3 suborbicular petals 3 times as long; anthers erect, turgid, deeply emarginate both ends.-Because of the alveolate rachis and the lack of female flowers in the type the author questioned the genus.

San Martín: Mount Campana, 1,000-1,300 meters, (Spruce 67, type). Moyobamba, (Weberbauer 4628; 585).-Junín: Chanchamayo, (Raimondi). Colonia Perené, (Killip \& Smith 24929).

Chamaeodorea Herrerae Burret, Notizbl. Bot. Gart. Berlin 11: 748. 1933.

Leaves small, the blades 4-4.5 dm. long, thin, the segments about 6 pairs, regularly disposed, the lower more approximate, all lanceolate-sigmoid, acuminate; apical segments nearly two times wider than the rest, the maximum seen about $2.3 \mathrm{dm}$. long, $3.5 \mathrm{~cm}$. wide; larger nerves in each segment (apical excepted) 5; fruiting spadix high, $2.5 \mathrm{dm}$. or more pedunculate; spathes narrowly cylindric; branches about 6, a dm. long; fruit insertions laxly spiralled, oblong or narrow, somewhat excavated, perianth closely costate, the short calyx 3-lobed, the outer petals imbricate; fruit obovoid, $9 \mathrm{~mm}$. long; embryo dorsally at slightly above the middle of the seed; male spadix peduncle slender, branches $10,1 \mathrm{dm}$. long, flowers rather densely spiralled, immersed, subglobose, the lower smaller; petals laterally free; anthers oblong, cells connate.-Distinguished from related species by the slender finely divided leaves; nevertheless, per- 
haps closest to $C$. geonomoides (Spruce) Drude with simple leaves (author).

Cuzco: Valle de Santa Ana, (Herrera 3641, male and female spadices, type). "Cuyuli."

Chamaeodorea integrifolia (Trail) Damm. Verh. Bot. Ver. Brandenb. 48: 125. 1906; 735. Morenia integrifolia Trail, Journ. Bot. 14. 331. 1876; var. nigricans Trail, l.c. M. Lechleriana Wendl. ex Damm. Gard. Chron. ser. 3, 36: 246. 1904.

To about 1.5 meters high, the simple submedially bifid leaves sometimes as long (petioles $3-5 \mathrm{dm}$. long, sheath $1.5 \mathrm{dm}$. long), nerves 12-20 pairs, the two (rarely $3-5$ ) segments broadly lanceolate, acuminate, to $1 \mathrm{dm}$. wide at base, the outer margin remotely denticulate; spadices (male) single, verticillate in the axils, slender, 5-6 dm. long, peduncles $3 \mathrm{dm}$. long, spathes $4-5$, imbricate; flowers remote, solitary, spiralled; calyx cupulate, petals orbicular, deep green; filaments slender, anthers free.-Burret noted that in spite of the difference in the number of primary nerves ex char. be believes $M$. Lechleriana to be the same and that a mixture of material may have occurred.Wood soft; flowers dark orange below, greenish above, violet-scented (Tessmann). Type of a variety with 3-5-parted leaves (dried dark) from Tabatinga at the boundary with Peru; also from Juruá Mirim and mouth of Río Tejo, nearly at the boundary (Ule).

Loreto: Mouth of Santiago, (Tessmann 4558).-Puno: San Gován, (Lechler, type, M. Lechleriana). To Colombia and Amazonian Brazil. "Sangapilla."

Chamaeodorea lanceolata (R. \& P.) Kunth, Enum. Pl. 3: 172. 1841; 755. Martinezia lanceolata R. \& P. Syst. Veg. 297. 1798.

Graceful, the stem often a little flexuose, a meter or two tall, 2-3 $\mathrm{cm}$. thick, the few (4-6) equally (mostly 5) pinnate leaves-1 meter long-borne laxly; leaf-segments lanceolate, sometimes narrowly, the lateral usually $2-3 \mathrm{dm}$. long, $2-4 \mathrm{~cm}$. wide, subequally multinerved, the terminal ovate-lanceolate, $7-9 \mathrm{~cm}$. wide, all acuminate; spathes 4 or 5, long-tubular; peduncles at least $2.5 \mathrm{dm}$. long, spadices $3-5 \mathrm{dm}$. long, the many branches of the male 1.5-2 dm. long, nutantarcuate, the fewer female suberect; male flowers about $4 \mathrm{~mm}$. across, calyx minute, annulate, petals cohering apically, the adnate stamens with erect anthers; female flowers depressed, obtuse; berry maturing black in the yellowish branches, $12-15 \mathrm{~mm}$. long, ellipsoid.-Illus- 
trated, Mart. Palm. Orbign. pl. 16A and Drude in Mart. Fl. Bras. 3, pt. 2: pl. 125. F.M. Neg. 18542.

Huánuco: Chinchao, Cuchero, (Ruiz \& Pavón, type). El Valle de Monzón, 700-900 meters, (Weberbauer, 593; 594).-Río Acre: Seringal Auristella, (Ule 9152). Bolivia; Brazil.

Chamaeodorea pauciflora Mart. Hist. Nat. Palm. 2: $5, p l .3$, fig. 3. 1823; 735. Morenia (?) pauciflora Drude in Mart. Fl. Bras. 3, pt. 2: 526. 1882. C. amazonica Damm. Notizbl. Bot. Gart. Berlin 6: 263. 1915, fide Burret.

Low, the petioles $2 \mathrm{dm}$. long, leaf-rachis $4.5 \mathrm{dm}$. long, segments of the ovate leaves opposite or subopposite, 9-10 pairs, 2-4 cm. distant, not decurrent, linear-lanceolate, sigmoid, about $2 \mathrm{dm}$. long, 1-2 cm. wide, lateral 3-, apical 4-6-nerved; peduncle of the simple female spadix $3 \mathrm{dm}$. long, spathe cylindric, obliquely open, rachis about 3-5 dm. long, gradually attenuate toward apex, flowers 3$4 \mathrm{~mm}$. distant, slightly immersed, calyx as corolla lobes ovate, acute, $1.5 \mathrm{~mm}$. long, $2 \mathrm{~mm}$. broad, the former 3 , dorsally puberulent, the latter 2, glabrous; staminodes minute, ovary subglobose, stigmas sessile.-After Dammer; Drude (l.c. 527), who also knew only the female flowers, suggested that the species apparently exhibits the characters of both Morenia and Chamaeodorea. The description of the Brazilian type agrees essentially: spadix rachis $3 \mathrm{~mm}$. thick, $2.5 \mathrm{dm}$. long, laxly scrobiculate, calyx urceolate, trifid, petals suborbicular, connivent, fruit ellipsoid, olive-black, 10 or $11 \mathrm{~mm}$. long, 7-8 $\mathrm{mm}$. in diameter, sarcocarp thin, embryo sublateral, inclined toward base. Type of Dammer's species from Juruá Mirim (Ule 5595), nearly at the Peruvian boundary. F.M. Neg. 18545.

Loreto (no doubt). Amazonian Brazil.

Chamaeodorea Pavoniana Wendl. ex Damm. Gard. Chron. ser. 3, 36: 246. 1904; 731. C. cataractarum Hort. not Liebm. ex Mart., 1849. C. Ruizii Wendl. l.c.?

Stems proliferous, 3-4 meters high, scarcely $2 \mathrm{~cm}$. thick; petioles 1-4 cm. long; leaves 5-8, simple, cuneate-obovate, more than medially furcate, 4-4.5 dm. long (or 3-3.5, fide Burret), the divergent divisions broadly lanceolate, acuminate, the inner margin straight, the apex slightly serrate-crenate; primary nerves $10-11$ pairs; spadices few-branched; fruit rounded-oblong, the seed rounded-ovate, $9 \mathrm{~mm}$. long, $8 \mathrm{~mm}$. broad (Dammer).-Near C. fragrans ex char. and perhaps doubtfully distinct. However, Burret (l.c.) noted that 
C. Ruizii Wendl. is not identical with C. fragrans but extraordinarily near $C$. Pavoniana; the leaves are little larger and the primary nerves 15-16; only known from sterile material.

Peru (fide Linden).

\section{MORENIA R. \& P.}

Reference: Burret, Notizbl. Bot. Gart. Berlin 13: 332-339. 1936.

Character of Chamaeodorea Willd. but calyx trilobed, the segments spreading in the male flowers, the corolla stellate, the lobes nearly free. Stamens erect (Drude).-Included in the former group by Bentham and Hooker and Dammer, but this is the earlier name. In view of the floral variations now known within the genus, sens. lat., only sectional divisions appear to be feasible. Drude's character is questionable, as the anthers may be erect (if included) in species accepted by him as Chamaeodorea. Dr. D. Gabriel Moreno was a physician of Lima, well-informed in botany and physical science (authors). Martinezia R. \& P. (Prodr. Fl. Peruv. 148. pl. 32. 1794) was named in honor of an archbishop of Colombia; Burret (Repert. Sp. Nov. 34: 169-170. 1933) showed, apparently correctly, that the name was based on a mixture of materials, including, among other groups, Morenia; in any case, it is expedient to follow Burret's decision and drop the name. The Willdenow name could be conserved.

Leaf segments lanceolate............. Poeppigiana, M. fragrans. Leaf segments linear. . ...........M. macrocarpa, M. linearis.

Morenia fragrans R. \& P. Prodr. Fl. Peruv. 140, pl. 23. 1794.

A slender graceful species, the type observed as 2 meters tall with 4 or 5 multipinnate leaves a meter long or longer; stem arundinaceous, slightly flexuose, more or less conspicuously annulate, scarcely 2.5 $\mathrm{cm}$. thick; pinnae lanceolate, divaricate, acute, $1.5 \mathrm{dm}$. long, medial wider than $5 \mathrm{~cm}$., midnerve prominent beneath, secondary 4-6, pale; spadices clustered, the female simply branched, to $5 \mathrm{dm}$. long, the male nutant.-Fruit, fide Orbigny, ellipsoid, black, 6-8 $\mathrm{mm}$. long. According to Martius in note under his $M$. Poeppigiana the leaf pinnae are somewhat broader, $4 \mathrm{dm}$. long, nearly $5 \mathrm{~cm}$. wide, a little more unequal and falcate-acuminate, spathes of the male spadix larger, and fragrant flowers a little longer, yellowish, and, finally, the fruit ovoid. Illustrated, Mart. Palm. Orbign. pl. 3, fig. 1 (plant); $16 c$ (stem, fruit, leaf); Bot. Mag. pl. 5492 (fide Hooker). 
Amazonas: Chachapoyas, (Mathews 31082).-Huánuco: Pozuzo, Muña, (Ruiz \& Pavón, type). Bolivia. "Siasia" (Ruiz \& Pavón), "san capilla" (Martius).

Morenia linearis (R. \& P.) Burret, Notizbl. Bot. Gart. Berlin 11: 316. 1932. Chamaeodorea linearis (R. \& P.) Mart. Hist. Nat. Palm. 2: 5. 1823; 3: 307. 1849. Martinezia linearis R. \& P. Syst. Veg. 297. 1798.

Leaves abruptly pinnate, the linear leaflets very acute; spadices compound, branches recurved and incurved, dioecious.-Apparently not re-collected unless as $M$. macrocarpa Burret. F.M. Neg. 29564.

Huánuco: Pozuzo, (Ruiz \& Pavón, type).

Morenia macrocarpa Burret, Notizbl. Bot. Gart. Berlin 13: 333. 1936.

Dioecious, 6 meters high, the rachis of the rather robust leaves glabrous, these with linear direct and gradually acuminate segments paler beneath, many nerves little more slender than the midnerve; fruiting spadix $4.5 \mathrm{dm}$. long, ascending at base, finally recurved; peduncle $2.5 \mathrm{dm}$. long, spathe-scars 5 ; rachis $12 \mathrm{~cm}$. long, the 20 branches cernuous; fruits spiralled, orange, $20-22 \mathrm{~mm}$. long, $13 \mathrm{~mm}$. in diameter; calyx scutellate, subtrilobed; seed obovate-oblong, 14 $\mathrm{mm}$. long, $1 \mathrm{~cm}$. in diameter; raphe branches 2 , the lower curved, the embryo a little above the middle; male spadix $2.5 \mathrm{dm}$. long, spathes 5 , the upper moderately inflated; peduncle $13 \mathrm{~cm}$. long, rachis $1 \mathrm{dm}$. long, branches 20-25, spiralled, slender, to $7 \mathrm{~cm}$. long; flowers rarely solitary, usually 2 or many together; calyx rounded-triangular; petals subovate, $2.5 \mathrm{~mm}$. long, equaled by the 6 stamens, these with oblong sagittate apically incised anthers.

Huánuco: Between Monzón and the Huallaga, (Weberbauer 3600, type; also 3597 , male).

Morenia Poeppigiana Mart. Hist. Nat. Palm. 3: 161. 1837; 309, pls. 140-141. 1849.

Seems to have no character distinct from $M$. fragrans as remarked by Hooker (Bot. Mag. pl. 5492. 1865), except that the male flowers are described as inodorous; leaf-pinnae about $3-4 \mathrm{~cm}$. wide, lanceolate-acuminate; lower spathe $2.5 \mathrm{~cm}$. long, upper $5 \mathrm{~cm}$. long.-Plate 140 is a landscape of the type locality with several small palms in the right foreground; plate 141, however, is a drawing of spadices in flower and fruit, and detailed analysis; Martius' description is com- 
plete but seems, ex char., to be without contrasting definitions. F.M. Negs. 29901; 29902.

Huánuco: Near Río Chinchao, (Poeppig, type).

\section{HYOSPATHE Mart.}

Reference: Burret, Notizbl. Bot. Gart. Berlin: 854-859. 1929.

Small, arundinaceous, the leaves pinnate or pinnatisect, the branched spadices below or between them, the small flowers monoecious, normally male. Spathes 2, long-fusiform, 3 together, not, in anthesis, immersed. Sepals of male flowers connate, petals narrow, valvate, both imbricate in female flowers, these with 3-celled ovary; staminodes present, but sometimes minute. Fruit slightly fleshy; embryo basal.

\section{KEY (after Burret)}

Leaf segments (known) with 1 primary nerve, $2.5 \mathrm{~cm}$. wide.

H. gracilis.

Leaves nearly simple or segments, at least mostly, several-nerved.

Spadices about 1.5-2 dm. long, lowest branches 5-13 cm. long.

Male flowers subsessile, only $2 \mathrm{~mm}$. long........... Ulei.

Male flowers pedicellate, $3 \mathrm{~mm}$. long........... Tessmannii.

Spadices larger, lower branches $2-4 \mathrm{dm}$. long.

Lower branches scarcely $2 \mathrm{dm}$. long; fruit $1.5 \mathrm{~cm}$. long.

Lower branches $2.5-4 \mathrm{dm}$. long.

H. elegans.

Male flowers sessile, about $3 \mathrm{~mm}$. long.......H. micropetala. Male flowers pedicellate.

Leaves basally long-cuneate; calyces and pedicels subequal. $H$. brevipedunculata.

Leaves not long-cuneate at base; pedicels longer than calyx. H. Weberbaueri.

Hyospathe brevipedunculata Damm. Verh. Bot. Ver. Brandenb. 48: 126. 1907. Geonoma Wittiana Damm. l.c. 124 as to leaves fide Burret, Notizbl. Bot. Gart. Berlin 11: 235. 1931.

Leaves, in outline, obovate, the lower of the two pairs of leaflets sigmoid, lanceolate, $4 \mathrm{dm}$. long, $5.5 \mathrm{~cm}$. wide, long-acuminate, 6nerved, the upper, placed $3.5-4 \mathrm{~cm}$. distant, similar (unless as to apex, unknown), nearly $4 \mathrm{dm}$. long, $9 \mathrm{~cm}$. wide, 9-11-nerved; spadix 


\section{Field Museum of Natural History-Botany, Vol. XIII}

rachis about $4 \mathrm{dm}$. long, peduncle $9 \mathrm{~cm}$. long, branches many, 1-1.5 $\mathrm{cm}$. pedicellate, 3-3.5 dm. long, flower glomerules about $5 \mathrm{~mm}$. distant; male calyx cupulate, 3-denticulate, corolla lobes lanceolate, $3 \mathrm{~mm}$. long, a third as wide; filaments unequal, the 3 longer $2 \mathrm{~mm}$. long, the shorter $1 \mathrm{~mm}$. long as the oval anthers; female calyx minutely denticulate, $1 \mathrm{~mm}$. long, the broadly lanceolate corolla lobes twice as long; staminodes minute, linear.-Petioles $2.5 \mathrm{~cm}$. long, leaf-nerves 11-12 (the synonym from nearby Seringal Belém, not Pará!). Type, Ule 5881, from Río Juruá Mirim, in adjacent Brazil; also collected at Seringal Belém on the same river.

Loreto (no doubt). Amazonian Brazil.

Hyospathe elegans Mart. Hist. Nat. Palm. 2: 1, pl. 2. 1823; $856 ; 521$ (Drude).

Trunk about 2 meters tall, to $3 \mathrm{~cm}$. thick; leaves 5 or more, lax or arcuate, at least a meter long, sheath 2-3 dm. long, truncate, petioles $1.5-2 \mathrm{dm}$. long, rachis 6-9 dm. long; segments many, various and mostly remote, nearly $5 \mathrm{dm}$. long, 1-nerved, linear-acuminate, 1.5 -nearly $2 \mathrm{~cm}$. long, the 6-8-nerved intermixed, lanceolate, $6-8 \mathrm{~cm}$. wide, the secondary nerves unequally interposed; spathe before anthesis subequaling spadix; peduncle and rachis of spadices subequal, the 12-24 divaricate branches mostly 2 (rarely 3.5 ) dm. long, near base $2 \mathrm{~mm}$. thick, much longer than rachis, rigid, attenuate; male flowers at least $3.4 \mathrm{~mm}$. long, the cupulate calyx segments much shorter than the broadly lanceolate petals, these exceeded by the stamens; female calyx $1.5 \mathrm{~mm}$. long, corolla about twice longer; fruit about $1.5 \mathrm{~cm}$. long, $8 \mathrm{~mm}$. in diameter.-Original material in part belongs to two or more species of Geonoma (Burret). Known from adjacent Brazil. Illustrated, Mart. l.c. pl. Z8, figs. 5, 6. F.M. Negs. 18527; 18528; 18528a (in part, $H$. filiformis Wendl.).

Loreto (probably). Amazonian Brazil.

Hyospathe gracilis [Poeppig] Wendl. ex Drude in Mart. Fl. Bras. 3, pt. 2: 523.1883 (err. sub nom. filiformis).

Slender, a meter or two high, the nearly equally pinnatisect leaves with linear-lanceolate falcate-acuminate more or less strongly veined and nerved segments, the solitary uppermost $3.5 \mathrm{dm}$. long, $2.5-3 \mathrm{~cm}$. wide, the upper pair about $2.5 \mathrm{dm}$. long, $8 \mathrm{~cm}$. wide, broadly connate; peduncles 2-3 $\mathrm{cm}$. long, spadices slender, $2 \mathrm{dm}$. long at base, rachis incrassate, branches about 30 , crowded, basal to $1.8 \mathrm{dm}$. long, apical to $1 \mathrm{dm}$. long, strict; glomerules 3 -flowered, approximate, male early 
3-4 mm. long, at anthesis broadly stellate, sepals all $1.5 \mathrm{~mm}$. long, petals basally connate, finally linear-lanceolate, long-acuminate, 3 $\mathrm{mm}$. long, stamens coherent toward base; female flowers ovoid, 1.5 $\mathrm{mm}$. long, sepals scarcely imbricate, the ovate acute petals twice longer.-F.M. Neg. 29888.

San Martín: Rocky island, Río Tocache, (Poeppig 2057, type).

Hyospathe micropetala Burret, Notizbl. Bot. Gart. Berlin 10: 857. 1929.

Type little more than 3 meters tall, the upper stem only 6-8 $\mathrm{mm}$. in diameter, internodes $2.3-3 \mathrm{~cm}$. long; sheath $12.5 \mathrm{~cm}$. long, truncate at apex, longitudinally nerved, nearly glabrous, sparsely scurfy; petioles $17 \mathrm{~cm}$. long, rounded except lightly canaliculate above; leaves thin, subconcolored both sides, elliptic or obovate-elliptic, nearly entire, apically bilobed or more or less unevenly 2-3 segmented each side and with 20 primary nerves, the rachis $24-29 \mathrm{~cm}$. long, the segments falcate, acuminate, the medial on upper margin about $26 \mathrm{~cm}$. long; spadix $33.5 \mathrm{~cm}$. long, glabrous, smooth; branches about 16 , slender, $22-25.5 \mathrm{~cm}$. long, very shortly bracteate at base; male flowers sessile, before anthesis $3 \mathrm{~mm}$. long, calyx $1 \mathrm{~mm}$. long, petals oblong, $2.5 \mathrm{~mm}$. long; anthers oval, scarcely $0.5 \mathrm{~mm}$. long.-Flowers orange, stamens bright brown, pleasantly scented (Tessmann).

Loreto: Inundated woods, San Antonio, mouth of Río Pastaza, (Tessmann 4935, type).

Hyospathe Tessmannii Burret, Notizbl. Bot. Gart. Berlin 10: 856. 1929.

Stem 2.5 meters high, $8 \mathrm{~mm}$. in diameter at the spadix, the internodes $2.5-3 \mathrm{~cm}$. long; sheath closely costate, sparsely fuscous scurfy as the petioles, these $1.5 \mathrm{dm}$. long, canaliculate above, roundedtriangular beneath; leaves subelliptic or possibly obovate-elliptic, about $5.5 \mathrm{dm}$. long, rather thin, drying dark, nearly concolor, primary nerves 19; rachis $3.5 \mathrm{dm}$. long; segments 3 pairs, falcate, narrowly acuminate, subequal or the basal slightly narrower, the medial on upper margin $3 \mathrm{dm}$., the apical about $25 \mathrm{~cm}$. long, 5-6.5 cm. wide; primary nerves at most $11 \mathrm{~mm}$. distant, the intermediary welldefined on both sides, numerous, the oblique transverse veins more obvious above; spadix in flower 15-19 cm. long, branches 7-9, spathes $17 \mathrm{~cm}$. long, about $1.7 \mathrm{~cm}$. across, glabrous and nearly smooth, obscurely costate; peduncle $3 \mathrm{~cm}$. long; lower branches $9.5-13 \mathrm{~cm}$. long, little flexuose to apex, basal bracts acute as the floral, these 
$7 \mathrm{~mm}$. long; pedicels rather robust, with calyx $3 \mathrm{~mm}$. long, teeth rather subfiliform, acute; petals $4.5 \mathrm{~mm}$. long, linear, at most $1 \mathrm{~mm}$. wide, densely striate; filaments filiform, $3 \mathrm{~mm}$. long, anthers linear, at least $1 \mathrm{~mm}$. long.-Petals scarlet, anthers white, leaves used for roofs (collector).

Loreto: Non-inundated woods, mouth of Río Santiago, (Tessmann 3980, type). "Palmiche."

Hyospathe Ulei Damm. Verh. Bot. Ver. Brandenb. 48:127. 1907.

A low (1-3 meter) slender palm with irregularly pinnatifid leaves - segments now 1-nerved, again many-nerved-and small $(1 \mathrm{dm}$. long) spadices; petioles about $1.5 \mathrm{dm}$. long, minutely brown-scaly as the 3-angled rachis; leaves ovate in outline with 4-5 uneven segments on each side, the lowest about 22 , the uppermost $16 \mathrm{~cm}$. long, the width $1.5-7 \mathrm{~cm}$.; lateral nerves 21 in all, each segment more or less sigmoid, long-acuminate; secondary nerves 2 between the primaries, 3-4 tertiaries between the secondaries; peduncle $2.5 \mathrm{~cm}$. long, $6 \mathrm{~mm}$. thick at base, rachis $1 \mathrm{dm}$. long, type with 10 lateral branches 4-7 cm. long, 3-7 mm. distant; lower flowers ternate, the 2 male $4.5 \mathrm{~mm}$. long; calyx $2 \mathrm{~mm}$. long, with $1 \mathrm{~mm}$. long tip; stamens unequal, anthers linear, $1.5 \mathrm{~mm}$. long; female calyx $1 \mathrm{~mm}$. long, corolla twice as long; staminodes filiform.-Unique in unevenly pinnate leaves and small spadix (author).

Loreto: Cerro de Escalero, (Ule 47P).

Hyospathe Weberbaueri Damm. ex Burret, Notizbl. Bot. Gart. Berlin 10: 858. 1929.

Three to 5 meters tall, the trunk about $17 \mathrm{~mm}$. in diameter beneath the spadix; petioles (known) $26.5 \mathrm{~cm}$. long, minutely and sparsely furfuraceous, rounded-triangular, the margins subacute; rachis $6.6 \mathrm{dm}$. long, extended into a filum above the fork of the rigid leaf-blade, this paler beneath and with 26 primary nerves to $1.5 \mathrm{~cm}$. distant; segments 3 on each side, the apical pair broader, all falcate, rather abruptly acuminate; secondary nerves conspicuous both sides, the obliquely transverse veins approximate; spadix of male flowers before anthesis $38.5 \mathrm{~cm}$. long, peduncle about $5 \mathrm{~cm}$. long; branches about 15, the lower $3 \mathrm{dm}$. long, the upper $2.5 \mathrm{dm}$. long, slender, flexuose; floral bracts shortly triangular; pedicels slender, with calyx $2 \mathrm{~mm}$. long, the former longer; petals linear, $4 \mathrm{~mm}$. long; filaments 2-5 mm. long, anthers linear; spadix with fruit (Weberbauer 3657) $48 \mathrm{~cm}$. long, peduncle $9.5 \mathrm{~cm}$. long, rachis blood-red, the 12 stout 
branches to $3.2 \mathrm{dm}$. long, toward apices strongly flexuous; mature fruit green, with perianth $12 \mathrm{~mm}$. long, without, $10 \mathrm{~mm}$. long, apically rounded, apiculate; perianth $3 \mathrm{~mm}$. high, calyx $2 \mathrm{~mm}$. long, teeth short, broad, petals 3 -angled.

Huánuco: Near Río Monzón toward Río Huallaga, 600-700 meters, (Weberbauer 3650, type; also 3657).

\section{JESSENIA Karst.}

Reference: Burret, Notizbl. Bot. Gart. Berlin 10: 301-312. 1928; 839-840. 1929.

In general character similar to Oenocarpus, at least in Peru, but minute calyx segments (all) imbricate, broadly cordate. Stamens $12-20$, anthers versatile on apically straight (type) or inflexed filaments, the anther connective produced. Male petals valvate, female convolute-imbricate. Fruit fibrous or also slightly succulent, the single seed with ruminate albumen, grooved within or irregular.Burret separates this from Oenocarpus chiefly on the basis of many (instead of 6) stamens and the ruminate albumen; both characters are sometimes variable in other groups (as Bactris, Euterpe) probably also the anther connective. When honored by Karsten, Carl Jessen was professor of botany at Eldena, Prussia.

Fruit 3-3.5 cm. long, entire spadix 1-2 meters long.....J. bataua. Fruit $4 \mathrm{~cm}$. long, spadix branches 1 meter long or longer.

J. Weberbaueri.

Jessenia bataua (Mart.) Burret, Notizbl. Bot. Gart. Berlin 10: 300, 302. 1928; 839. Oenocarpus bataua Mart. Hist. Nat. Palm. 2: 23, pls. 24, 25. 1823.

Only in age the columnar stems smooth when 20 meters high or higher, $2 \mathrm{dm}$. in diameter, in youth more or less marked by or enclosed in the spiniform remnants of the leaf-sheaths; leaves 8-10, crowded, erect-spreading, 10 meters long or longer, the equally distant segments linear-lanceolate, mostly about 2 meters long, $1 \mathrm{dm}$. wide; spadices few, 1-2 meters long, the many branches fastigiate, strict, incrassate above; lower spathe half as long as upper, extended into a fuscous tomentose mucro; male petals ovate-oblong, subacute; fruit violet-purplish, cylindric-ellipsoid (stigmas nearly on the rounded apex), 3-3.5 cm. long, $2-2.25 \mathrm{~cm}$. in diameter, the oblong seed acute at both ends.- Known from Ríos Japurá and Ica, adjacent Brazil; no doubt occurs in Peru. $J$. polycarpa Karst. (Ill., Fl. 
Colomb. 1. pl. 98), listed by Dahlgren as in Peru, and certainly similar, is apparently known only from Venezuela and Colombia; the "Marañón" mentioned by Karsten cannot be Río Marañon of Peru. Burret (Notizbl. Bot. Gart. Berlin 10: 839. 1929) observed that this species actually has rings of thin white fibers on the upper part of the stem and is distinct from J. bataua. Illustrated, Wallace, Palm Trees Amazon, pls. 10, 11.

The thin mesocarp, triturated with water, forms a creamy sweetish beverage similar to that from fruits of Euterpe (Spruce).

Peru (probably). Brazil to Guiana. "Ungurauy," "sacumana."

Jessenia Weberbaueri Burret, Notizbl. Bot. Gart. Berlin 10: 840. 1929.

Caudex 12 meters tall, nearly $4 \mathrm{dm}$. in diameter, leaves 10 meters long, rachis $1.5 \mathrm{dm}$. thick (collector), upper fragment seen $3.5 \mathrm{~cm}$. high, $2.5 \mathrm{~cm}$. broad, ashy furfuraceous, the regularly disposed segments $4-5 \mathrm{~cm}$. distant, linear, 5-6 cm. wide, apex abruptly contracted, bifid, paler beneath, sigmoid or falcate, perhaps plicate above along the longer nerves; fruiting spadix lustrous; peduncle very stout, below the lower spathe $12.5 \mathrm{~cm}$. thick, below the upper $11.5 \mathrm{~cm}$., above that and at the lower branches $8.5 \mathrm{~cm}$. in diameter, the space between the spathe scars $9 \mathrm{~cm}$., between the upper of these and the lower branches $6.2 \mathrm{~cm}$.; branches stout, minutely bracted at base, about 1 meter long or longer, the peduncles 1-2 meters longer, these apically $7 \mathrm{~mm}$. thick, medially $8 \mathrm{~mm}$. thick; vestigial flowers mostly ternate, the 2 lateral male; fruit oblong, $4 \mathrm{~cm}$. long (3.8 without perianth), $2.3 \mathrm{~cm}$. broad, beak short, slightly excentric; perianth to $1.5 \mathrm{~cm}$. high, segments rhombic; seed $2.5 \mathrm{~cm}$. long, $1.5 \mathrm{~cm}$. in diameter.-Unique in large fruit and long, very stout branches; fruit of $J$. polycarpa Karst. without perianth is $3.3 \mathrm{~cm}$. long (Burret).

San Martín: Moyobamba, (Weberbauer 4561, type). "Sinami."

\section{OENOCARPUS Mart.}

Reference: Burret, Notizbl. Bot. Gart. Berlin 10: 291-301. 1928.

Slender, tall, the unarmed trunks often in clusters, the leaves pinnatisect, the spadices infrafoliar in base of dense coma, simple or divided. Upper spathe exceeding lower, often acuminate. Flowers monoecious, not immersed, the lower or all 3-glomerate, the intermediate usually female. Stamens 6 , anthers versatile; sepals as 
petals valvate, unless at base. Female flowers much smaller, segments imbricate, staminodes commonly obsolete. Fruit 1-seeded, drupiform, more or less fibrous or succulent, stigma terminal or subterminal (type). Seed with plane albumen, embryo basal.-The name, "wine fruit," applies best perhaps to the species "Pataua" or "Bataua," now, probably not necessarily, separated as part of a distinct group, Jessenia. For convenience the two species of the latter are included in this key.

Leaf-segments long-acuminate, mostly aggregate.

Trunks solitary .......................... bacaba.

Trunks clustered........................ multicaulis.

Leaf-segments abruptly acuminate, laxly distant; trunks solitary.

Segments $4-5 \mathrm{dm}$. long ...................... minor.

Segments 1-2 meters long (see Jessenia for descriptions).

Fruit $3-3.5 \mathrm{~cm}$. long..................... bataua.

Fruit $4 \mathrm{~cm}$. long.....................Weberbaueri.

Oenocarpus bacaba Mart. Hist. Nat. Palm. 2: 24, pl. 26, figs. 1-2. 1823; 469 (Drude).

Stem solitary, to 20 meters tall, $1.5-2 \mathrm{dm}$. in diameter, the marcescent sheaths persisting below the dense spreading coma of 8 or more leaves, these about 5 meters long with many crowded (in clusters of 2-6) linear-lanceolate acuminate segments a meter or more long, 4-5 cm. wide; spathes lignescent, caducous before anthesis; spadices usually many, flowering and fruiting dependent beneath the coma; upper spathe twice longer than lower; spadix branches $5 \mathrm{dm}$. long or longer, strict, basally pedicelliform; male flowers $7 \mathrm{~mm}$. long, petals ovate-oblong, acute, short calyx cupulate, stamens early connivent, anthers bifid; female flowers depressed globose, $5 \mathrm{~mm}$. high, the large sepals (enclosing petals) convolute-imbricate; fruit purplish, pruinose, globose-ellipsoid, plum-like, acute, $2.5 \mathrm{~cm}$. long, $2 \mathrm{~cm}$. thick, the stigmas apical; seed $16 \times 12 \mathrm{~mm}$.-Type from Río Negro; collected also on Río Solimöes. Illustrated, Wallace, Palm Trees Amazon, pl. 9; Drude, Mart. Fl. Bras. 3, pt. 2: pl. 108, fig. 3 (fruit).

San Martín: Tocache, (Poeppig, fide Drude).

Oenocarpus minor Mart. Hist. Nat. Palm. 2: 25, pl. 27 (part). 1823; 471 (Drude).

Stem solitary, to 10 meters high with a diameter of $7.5 \mathrm{~cm}$. or less, annulate; leaves many in a dense coma, of ten 2-3 meters long, equally 
pinnate, the 50-60 segments 4-5 dm. long, 4-5 cm. wide, lanceolate, abruptly attenuate-acuminate apex, strongly 5-plicate, glaucous or puberulent beneath; spadices below leaves, about $3 \mathrm{dm}$. long, the 25-35 simple branches $2.5-3 \mathrm{dm}$. long, early flexuose toward base; spathes fuscous tomentose, deciduous after anthesis, the upper rostrate; male petals acute, $3 \mathrm{~mm}$. long; segments of female flowers all reniform-orbicular; fruit lustrous, black, ellipsoid, cusped apically, $1.5 \mathrm{~cm}$. long, $1 \mathrm{~cm}$. in diameter.-The fusiform sheaths are more than double the diameter of the stem, open with a single slit, split up into soft fibers, soon fall away (Spruce). Said to occur in all the wooded valleys of the Río Amazon and listed by Dahlgren (222) as in Peru. Illustrated, F.M. Negs. 18853; 18853a; Drude, l.c. pl. 108 (fruit).

Peru (probably). Brazil; Venezuela. "Ciamba," "manaqui."

Oenocarpus multicaulis Spruce, Journ. Linn. Soc. 11: 142. 1871; 299 (Burret); 470 (Drude).

Stems clustered (6-10), 3-10 meters high, to $1.5 \mathrm{dm}$. thick, remotely annulate; leaves broadly lanceolate, 3-4 meters long; sheath $9.5 \mathrm{dm}$. long, ventricose, splitting down the middle into fibers and finally deciduous with the leaf; leaf-segments about 60 each side, linear-lanceolate, acute, about 1 meter long, 7-8 cm. wide, the lower and apical equidistant, the rest 2-3-aggregate, all glaucous or whitishpulverulent beneath; spadix shortly $(7 \mathrm{~cm}$.) pedunculate, scapiform, deciduous spathe tomentose, the lower $2.5 \mathrm{dm}$. long, the upper $6 \mathrm{dm}$. long, elongate-fusiform, obtusely rostrate; rachis 1 meter long, branches many, nearly $5 \mathrm{dm}$. long; flowers shortly bracteolate at pit, male flowers yellowish, petals ovate-lanceolate, little exceeding stamens, female flowers whitish, sepals and petals finally orbicular; fruit ellipsoid, cusped, stigma apical, $2.5 \mathrm{~cm}$. long, $2 \mathrm{~cm}$. in diameter, black-purple, mesocarp thin, sweet, the seed oblong.-Fruit edible (Tessmann).

San Martín: Tarapoto, (Spruce 63, type).-Loreto: Mouth of Río San Isidro, (Tessmann 4995). "Ciamba," "ciama," "sinami," "sinamillo."

\section{EUTERPE Gaertner}

Reference: Burret, Bot. Jahrb. 63: 49-76. 1929.

Slender, often tall, monoecious, the trunk smooth but annulate, solitary (Peru), the petiolar sheaths of the pinnate leaves forming a conspicuous crown-shaft. Spadices inter- or infrafoliar, the short 
outer spathe open apically, the inner elongate, often rostrate; branches slender, few to many, spreading or pendent. Flowers in groups of 3, sometimes partly or deeply immersed; stamens 6, petals valvate, sepals imbricate as also petals of female flowers; staminodes ordinarily obvious. Fruit small, subglobose, drupe-like, 1-celled, the stigmatic scar lateral or subapical, early somewhat succulent, soon hard; seed with plane or ruminate albumen, the embryo lateral (or essentially apical; Bailey).-The contradiction in characters accepted within this group points up the tenuous lines of generic demarcation in the family. Bailey (Gentes Herb. 7: 417-419. 1947) discussed the validity of the name and suggested that the presence of clearly homogeneous and completely ruminate albumen and superficial or pitted flowers may indicate two genera.

Early leaves simple, bilobed; filaments apically geniculate; petals obtuse; female flowers superficial; albumen ruminate.

Peduncle and rachis subequal............E. ensiformis.

Peduncle somewhat shorter than rachis.......E. megalochlamys. Early leaves flabellate-pinnate; filaments straight; petals obtuse; female flowers somewhat immersed.........E. precatoria.

Euterpe ensiformis (R. \& P.) Mart. Hist. Nat. Palm. 2: 32, pl. 31. 1824; 58. Martinezia ensiformis R. \& P. Syst. Veg. 1: 297. 1798.

Caudex erect, cylindric, 12 meters tall; leaf pinnae subensiform, very long-acuminate; rachis laxly flowered; sepals of male flowers broadly triangular, 4 times shorter than ovate petals, roseate within, female whitish; fruit globose, about 6 or $7 \mathrm{~mm}$. in diameter, dull blue-black, the stigma scar excentric, scarcely succulent (Kunth).Trunk slender, curved, leaves about 8 , pinnae horizontal, spadix rachis and long peduncle subequal (Tessmann); 5-12 meters high, leaf (with petiole, this 6-10 dm. long) 3-4 meters long, spadix rachis rose-red, fruit olive-green (Weberbauer). F.M. Neg. 18555.

Huánuco: Pozuzo, (Ruiz \& Pavón, type; Tessmann, fide Burret). Near Río Monzón, 600 meters, (Weberbauer 3585). Monzón, 900 meters, (Weberbauer 3438). "Cuyol," "coyol."

Euterpe megalochlamys Burret, Bot. Jahrb. 63: 59. 1929.

Type with caudex 7 meters tall, leaves $12 \mathrm{dm}$. long-the rachis early fuscous tomentose-the nutant fruiting spaaices glabrous, about $7.5 \mathrm{dm}$. long, the peduncle somewhat shorter; leaf-segments 
subregular, about 40 on each side, the lower $27 \mathrm{~cm}$. long, to $1 \mathrm{~cm}$. wide, the medial to $32 \mathrm{~cm}$. long, $2 \mathrm{~cm}$. wide, the upper $11 \mathrm{~cm}$. long, $1 \mathrm{~cm}$. wide, all flexible, paler beneath, mid-nerve prominent above as the 3 secondary nerves (besides marginal) both sides, abruptly acute, often subcucullate or bifid; bracts at base of the many rachis branches (these 2-3.5 dm. long), oblong, acute, $2.5 \mathrm{~cm}$. long; fruits densely spiralled, 10 or $11 \mathrm{~mm}$. in diameter, light brown, smooth, the stigma residuum above the middle; perianth (in fruit) $8 \mathrm{~mm}$. across, calyx a third shorter than corolla, both smooth; seed $7 \mathrm{~mm}$. long, $8 \mathrm{~mm}$. broad, albumen deeply ruminate.

La Libertad: Valle Río Mixiollo, 1,900 meters, (Weberbauer 7070, type).

Euterpe precatoria Mart. Palm. Orbign. 10. pls. 8, 18.1847; 70.

Caudex strict, 12-20 meters tall, $1.5 \mathrm{dm}$. in diameter at base, $7 \mathrm{~cm}$. at apex; sheaths cylindric, 3 times shorter than the 12-15 spreading leaves, these to 3 meters long with approximate lax or pendent linear long-acuminate pinnae $6 \mathrm{dm}$. long or longer; spadices infrafoliar, the sheaths reddish tomentose, the branches $4.5 \mathrm{dm}$. long, flowers crowded, flavescent; petals of the male broadly lanceolate, acute; sepals and petals of the female suborbicular; fruit globose, 8-10 $\mathrm{mm}$. diameter, residual stigmas excentric; albumen plane.Dahlgren, 185, lists locality Maynas (i.e. the area of Yurimaguas); Huber found it common on the Río Solimöes and it is also known from adjacent Colombia and Bolivia (the type).

Peru (probably). Colombia to Bolivia. "Yuyu-chonta" (Dahlgren).

\section{ORBIGNYA Mart.}

Reference: Burret, Notizbl. Bot. Gart. Berlin 10: 493-516. 1929.

Character in general resembles that of Attalea HBK. but the free anther cells of the 12-24 stamens are elongate and contorted or sinuous, petals ovate or ovate-lanceolate, plane. Fruit 2-6-seeded.It is curious that, as independent developments, similar anther contortion occurs in some exogens, as Bombacaceae, Cucurbitaceae and Columelliaceae. Burret (l.c. 493-497) has presented well the relative characters of this and related genera; as he remarks, male flowers are necessary to recognize this genus and it may be suggested that at least in floristic work expediency should take precedence over emphasis of a single technical characteristic so that 
determination may be more practical, at least rarely if ever impossible. Indicative of the closely uniform development of these groups may be the occurrence in each of similarly distinctive characters, as Burret makes clear.

The distinguished naturalist, Alcide D'Orbigny, of the Natural History Museum of Paris, collected in southern Peru in 1830 and 1834. 1932.

Orbignya polysticha Burret, Notizbl. Bot. Gart. Berlin 11: 324 .

Acaulescent (or shortly caulescent); leaves 4 meters long, rachis (fragment, probably medial) laterally excavated, fuscous furfuraceous as segments beneath, especially apically, these (few seen) apparently regularly disposed, narrowly reduplicate at base, $8 \mathrm{dm}$. long, $3.2 \mathrm{~cm}$. wide, concolor, larger nerves few, densely and finely nervose-striate, the transverse veins prominent both sides, many short, others 6 or $7 \mathrm{~mm}$. long, narrowly produced; male spadix (part) $3 \mathrm{dm}$. long, glabrous rachis $22 \mathrm{~cm}$. long, branches simple, upper flowers strongly congested; lower branches 7-9 cm. long, sterile for 2-4 cm., sparsely ovate-acuminate bracteate; spikes 3-4 $\mathrm{mm}$. thick or with flowers nearly $2 \mathrm{~cm}$. in diameter, these spirally in 8 or 9 series, the impressed binate flowers about $7 \mathrm{~mm}$. long, conspicuously bracteate, bracteoles minute, petals strongly involute apically; calyx $1 \mathrm{~mm}$. high; petals spathulate, linear at base, suborbicular at tip; stamens 15 , filaments filiform, subglobose anthers more or less contorted.-Only O. Dammeriana Barb. Rodr., origin unknown, has spiralled flowers and it is not closely related, according to Burret, who referred here with little doubt the second collection, this however with stem $4 \mathrm{dm}$. high, leaf segments $6 \mathrm{dm}$. long, $1.8 \mathrm{~cm}$. wide, edible fruit dark orange.

Loreto: Mishuyacu near Iquitos, (Klug 205, type). Santa Rosa, below Yurimaguas, (Killip \& Smith 28814). "Catirina."

\section{ATTALEA HBK.}

Reference: Burret, Notizbl. Bot. Gart. Berlin 10: 517-543. 1929.

Tall or low (rarely stemless), smooth, the leaves pinnate, the flowers monoecious in each spadix (rarely in each tree), this simple or simply branched. Stamens 6-many, filaments free, anther parallel, often exserted, the calyx segments small, free or connate at base, the petals valvate. Female flowers much the larger, sepals as petals imbricate, coriaceous. Fruit ovoid or oblong-ellipsoid, cusped or pointed, 1-3 (-5) -seeded, fibrous, $3(-5)$-pored at base. 
Cocos (C. nucifera L., coconut or cocotero), cultivated for the wellknown subtrigonal-ovoid fruit, also 3-pored at the base, is now regarded as a monotype genus; other palms besides Attalea HBK. that are native to Peru and in general similar include particularly Syagrus Mart., Scheelea Karsten, Orbignya Mart. and Maximilliana Mart. See Burret's thoughtful discussion (1.c. 493-497).

Attalea Tessmannii Burret, Notizbl. Bot. Gart. Berlin 10: 538. 1929.

Vegetatively incompletely known but ex drawing by collector petioles laterally fibrous, leaf-segments at least the lower irregular, perhaps disposed in groups; spathe about $24 \mathrm{dm}$. long, relatively thin, extended rather suddenly into a long small beak; female spadix branches many, 2 (seen) $5 \mathrm{dm}$. long, virgate, 5 smaller $13-18 \mathrm{~cm}$, all certainly from same plant, basal bracts linear, acute, rigid, 2.2$3.5 \mathrm{~cm}$. long, glabrous, one flower in shallow pit 5-7 cm. above the base; basal bract about $2.5 \mathrm{~cm}$. long, floral bracts broadly ovate; sepals oblong, longer than petals; stigmas 3; lower sterile male flowers above female remotely, then rather densely spiralled, the bracts mostly 3 (lower 5) $\mathrm{mm}$. long; sepals and petals linear or sublanceolate, to $1.5 \mathrm{~cm}$. long, stamens 12, a third as long (anthers sterile); fruits (with perianth and beak) $12-12.5 \mathrm{~cm}$. long, $5 \mathrm{~cm}$. across or broader, fuscous furfuraceous, more or less abruptly apiculate with beak 2-2.5 cm. long, style with stigmas conically protracted; perianth in fruit at least one-third as long as the latter, segments ovate to broadly ovate, broadly apiculate, petals somewhat longer; mesocarp $3 \mathrm{~mm}$. thick, mostly fibrous, the multifibrose endocarp dark-colored; male spadix branches $25-27 \mathrm{~cm}$. long, rigidly bracted, the flowers more or less spiralled in 5 little inclined, 3 strongly inclined series, 2 in juxtaposition in axils of very rigid bracts, the smaller bractlets ovate-oblong; flowers $1.5 \mathrm{~cm}$. long, sepals oblong, $1.33 \mathrm{~mm}$. long, petals acute, costate-nerved, denticulate, minutely scabrous; stamens 12 , anthers sagittate, linear, about $5 \mathrm{~mm}$. long; pistil reduced, the 3 subulate styles $1 \mathrm{~mm}$. long.-No other unquestionably dioecious species is known to me from the four related genera; the species is further especially noteworthy by the conspicuously bracted relatively thick spikes of spirally disposed male flowers, and by the abundant fibrous tissue of the dark-colored endocarp (author).

Cultivated at Pará and collected by Huber, probably on the Río Ucayali (Burret, l.c. 12: 155. 1934). 
Loreto: Flood-free woods, Soledad, lower Río Itaya, (Tessmann 5167 , type; $5167 a$, male). Yarina-cocha, middle Ucayali, (Tessmann 5395, male). "Conta."

\section{SYAGRUS Mart.}

Resembles Scheelea but the putamen of the acute 1-seeded fruit rugose within except for 3 smooth bands. Female flowers smaller than male, disk prominent. Stamens 6, exceeded by the lanceolate petals.-Bentham and Hooker followed Drude in regarding this as a subgenus of Cocos L.; however, compare Scheelea Karst. and Attalea $\mathrm{HBK}$.

\section{Syagrus Tessmannii Burret, Repert. Sp. Nov. 32: 106. 1933.}

Caudex to 20 meters tall, in type $3.5 \mathrm{dm}$. in diameter at base, $1.5 \mathrm{dm}$. at the coma of 17 leaves; petioles 1.5 meters long, dilated toward base, marginally tomentose; sheath fleshy coriaceous, semicircular at base dissolving into an intermixed mass of fine and very fine fibers; leaf-rachis 3.1 meters long; segments about 160, base to apex mostly in distinct groups of 3-4, the basal very narrow and shorter, the upper about $2.5 \mathrm{dm}$. long (rarely 1 meter long, $5 \mathrm{~cm}$. wide), all acuminate, glabrous, slender nerves few above, many beneath, obvious, transverse veins obsolete; spadices large, interfoliar; upper spathe ventricose, 1 meter long, deeply sulcate, deciduously scurfy tomentose; peduncle at apex nearly $3 \mathrm{~cm}$. broad, rudimentary spathes or bracts linear or lanceolate, 1-2; branches straight, many, rather densely spiralled on the long rachis, to about $5 \mathrm{dm}$. long, all flowers male (no rudimentary female), scrobiculi shallow, 2 -flowered except toward apex, bracts most minute; flowers ellipsoid-rotund, to $12 \mathrm{~mm}$. long, calyx $2 \mathrm{~mm}$. long, sepals oblong-lanceolate, carinate, petals oblong-subobtuse; filaments $2.5 \mathrm{~mm}$. long, anthers linear, sagittate, to $7 \mathrm{~mm}$. long; fruit (after Tessmann drawing) yellowish, oval, erostrate, with perianth $33 \mathrm{~mm}$. long, $24 \mathrm{~mm}$. in diameter; female spadix larger and each flower with 2 sterile male flowers on the larger part of the many branches; fruiting bracts minute, broadly rotund; flowers (known) before anthesis $8 \mathrm{~mm}$. high, about $6 \mathrm{~mm}$. broad, rounded-ovoid; sepals as shorter petals slightly imbricate in bud, not seen in anthesis; sterile flowers 6-10 mm. long, calyx 1-2 mm. long, petals oblong-elliptic.- The collector's painting shows an individual tree with male flowers and fruit. From the Brazilian S. inajai (Spruce) Becc. and S. ecuadoriensis Becc. this species is distinct by the thinner leaves without transverse veins; notable is the cushion 
of fibers of the young sheaths; it may be illustrated by Huber (Bull. Herb. Boiss. sér. 2, 6: $p l$. 13, as a species of Cocos) under a nomen nudum (tall, the spadix much-branched), which, of course, must become a nomen dilendum as suggested by Burret; the transfer of Huber's name without description also gave it no standing.

Fleshy fruit eaten by cattle; stem, used for construction, harbors edible larvae, the wood serves for lances, etc. (collector).

Loreto: Mouth of Apaga, (Tessmann 4811, type). Middle Ucayali, Río Ayuaytia, (Tessmann 3286, female spadix). "Inchaui," "intshawui."

\section{SCHEELEA Karst.}

Reference: Burret, Notizbl. Bot. Gart. Berlin 10: 651-689. 1929.

Resembles Orbignya Mart. and Attalea HBK. but the petals of the male flowers are fleshy, elongate-clavate or cylindrical, and the stamens are straight as in the latter but only 6 . Fruit 1-3-seeded, the seeds ellipsoid, albumen plane.-Cymba (spathe-valve) heavy, ligneous as in Attalea. S. Wallisii (Huber) Burret (1.c. 657) from the Río Ucayali is essentially a nomen nudum. Huber (Bull. Herb. Boiss. sér. 2, 6: 267. 1907) described the drupes as ellipsoid-cylindric; only original material will enable identification (Burret). Only one species in the following key after Burret is acaulescent.

Stigmas (as cells) mostly more than 3 ; female flowers in mostly 1-5 branches; fruiting bracts large; endocarp fibers large (section Syncalphocaryum Burret).

Acaulescent......................... Weberbaueri. Caulescent.

Leaf-segments regularly disposed............S. Bassleriana. Leaf-segments $2-4$-aggregate............... cephalotes. Stigmas mostly $1(-3)$; female flowers lax on 5 or more branches; bracts as fibers small (section.Dialphocaryum Burret).

Fruit rounded, the beak slender, the perianth to $2 \mathrm{~cm}$. high.

Perianth one-third as large as fruit; flowers (male) $1.5 \mathrm{~cm}$. long, yellow......................... stenorhyncha.

Perianth one-fourth as large as fruit; flowers (male) $1 \mathrm{~cm}$. long, yellowish........................ S. brachyclada.

Fruit extended into thick beak; flowers yellowish, female $2.5 \mathrm{~cm}$. long, male $1.5 \mathrm{~cm}$. long................ Tessmannii. 
Scheelea Bassleriana Burret, Notizbl. Bot. Gart. Berlin 10: 655. 1929.

Type 12 meters tall, fragment (apical) of leaf seen about 1 meter long, its narrowly linear rachis fuscous furfuraceous only beneath, the acutely angled segments gradually decreasing in size, regularly disposed, narrowly reduplicate at base, linear, long-acuminate, shortly and unequally bifid, subpruinose beneath, green above, midnerve very prominent, secondary nerves obscure, transverse conspicuous, obsolete beneath; male spadix (fragment) branches about 2-2.5 dm. long, bracts scarcely $2 \mathrm{~mm}$. long, abruptly contracted, the flowers densely spiralled; petals $14 \mathrm{~mm}$. long, stamens one-third as long, anthers oblong, $3 \mathrm{~mm}$. long; fruit oval, $9.5 \mathrm{~cm}$. (with perianth) long, $5-5.5 \mathrm{~cm}$. in diameter, slender acumen of rounded apex $1 \mathrm{~cm}$. long; perianth cupulate, $2.4 \mathrm{~cm}$. high, sepals ovate, subacuminate, $2.8 \mathrm{~mm}$. long, little longer than the broader petals; mesocarp (dried) entirely fibrous, $4 \mathrm{~mm}$. thick, endocarp 3-celled, $8 \mathrm{~mm}$. thick, densely and rather regularly spotted, the many fibers mostly 2-4-aggregate, small fibers nearly none.-Trunk to $4 \mathrm{dm}$. in diameter, flowers yellowish, oily flesh of fruit edible (Tessmann); name commemorates supporter of botanical work.

Loreto: Yarina-cocha, Río Ucayali, (Tessmann 5490, type; also 3266). "Shevao," "shebon."

Scheelea brachyclada Burret, Notizbl. Bot. Gart. Berlin 10: 680. 1929.

Apical part of leaf seen $9 \mathrm{dm}$. long, glabrous, the rachis triangular, segments reduced upward, nearly regularly disposed, spreading in one plane (lower probably aggregate?), narrowly linear, reduplicate at base, rounded but bidentate at apex, medial nerve prominent above as 3 lateral nerves each side, the numerous transverse ones obvious only above; female branchlets many (broad-based bract pungently acuminate), 1-1.5 dm. long, upper fourth to half bearing sterile male flowers, lower part 4-5 (rarely 3 ) secund or subdistichous female, the cupulae of bracts $1 \mathrm{~cm}$. across, about $2.5 \mathrm{~cm}$. long; sepals long-triangular, longer than petals, equaling stigmas; fruits with perianth $7 \mathrm{~cm}$. long, $3 \mathrm{~cm}$. in diameter, oblong-cylindric, the subrotund apex with beak-like style 7 or $8 \mathrm{~mm}$. long, transverse section 1-seeded ( 2 cells aborted), mesocarp $2.5 \mathrm{~mm}$. in diameter, entirely fibrous, endocarp $8 \mathrm{~mm}$. thick, fibers brown, often few aggregate; perianth in lobes $2 \mathrm{~cm}$. high, sepals and petals ovate, the latter very broadly, abruptly contracted; male spadix branches small, slender 
(basal bracts 1.5-2 cm. long), 10-12.5 cm. long, floriferous to $1.5 \mathrm{~cm}$. of base, rather crowded flowers finally subsecund; floral bracts minute, suborbicular; flowers 8 or $9 \mathrm{~mm}$. long, petals subulate, about twice as long as stamens (anthers $2.5 \mathrm{~mm}$. long), sepals oblong, $0.5 \mathrm{~mm}$. long.-Description of leaves and male spadix from 5493, which collection was accompanied by careful drawing of fruit so that the identity is scarcely to be doubted (Burret); fruit, from the aquarelle, $8.3 \mathrm{~cm}$. long, $3.5 \mathrm{~cm}$. in diameter, $9 \mathrm{~mm}$. rostrate from pulvinateconic style, perianth lobes $2.5 \mathrm{~cm}$. high. Differs-as $S$. Tessmannii -from the obscure S. kewensis Hook. f. (Bot. Mag. pls. 7552, 7553. 1897), cultivated, by the not exserted stigmas.

Loreto: Soledad, Río Itaya, (Tessmann 5237, type). Yarinacocha, middle Ucayali, (Tessmann 5493).

Scheelea cephalotes (Poepp.) Karst. Linnaea 28: 269. 1856; 660 . Attalea cephalotes Poepp. ex Mart. Palm. Orbign. 10: 119. 1847.

Type with caudex several meters tall, smooth below, residual petioles toward apex among the leaves, these to 3 meters long including the petioles, fibrillose toward base and to 1 meter long; leaf-rachis lepidote-tomentose, pinnae reduplicate (2-4-aggregate), about 1$2.5 \mathrm{~cm}$. distant, linear, acuminate, to 1 meter long, $16-18 \mathrm{~mm}$. wide, pale green, punctate beneath, the midrib prominent above, acute, secondary fewer than 8 , branches of male spadices about $1 \mathrm{dm}$. long, densely fastigiate, subterete, flexuose below; bracts minute, flowers 8-10 mm. long, calyx minute, ovate-suborbicular segments apiculate, petals linear, subfleshy, shortly acute, anthers subsessile; female spadix bracteate at base, coriaceous bractlets 2 , flowers unknown in type; fruit nearly $1 \mathrm{dm}$. long, about $3.5 \mathrm{~cm}$. in diameter, fibrose without, fleshy within, the residual stigmas apical; seed solitary, linear-oblong, subtrigonous, albumen cartilaginous.Weberbauer noted stem 7 meters high, fruiting spadix without peduncle $6 \mathrm{dm}$. long, $3.5 \mathrm{dm}$. across. Illustrated, Mart. Hist. Nat. Palm. 3. pl. 169. F.M. Neg. 31307.

Huánuco: Mouth of Río Pozuzo, (Weberbauer 6762).-Loreto: Yurimaguas area, (Maynas), Poeppig, type. "Shapaja."

Scheelea stenorhyncha Burret, Notizbl. Bot. Gart. Berlin 10: 675. 1929.

Type with stem $4 \mathrm{dm}$. in diameter, 25 meters high, bearing 1518 leaves; male spadix branches $2.5-3.5 \mathrm{dm}$. long, bract $7 \mathrm{~mm}$. long, 
farinose puberulent, flowers spiralled, attenuate to nearly acute apex; floral bracts ovate, pungent, minute; flowers $17 \mathrm{~mm}$. long, yellow, sepals oblong, petals scarcely broader than $1 \mathrm{~mm}$.; stamens onefourth as long as flowers, anthers nearly $3 \mathrm{~mm}$. long; fruiting branch female below, fruits spiralled; bracts forming a cup about $1 \mathrm{~cm}$. across; perianth in fruit $1.8-2 \mathrm{~cm}$. high, to $2.5 \mathrm{~cm}$. in diameter; sepals, petals subequal, about ovate, abruptly acute; fruit cylindric, $6 \mathrm{~cm}$. long (with perianth and beak), 2.3-2.5 cm. in diameter, beaks 5-7 mm. long, transverse section 1-seeded ( 2 cells obliterated), mesocarp thin, entirely fibrous, endocarp cinnamon-colored, $6 \mathrm{~mm}$. thick, inner fibers none.-Related to $S$. regia Karst. of Colombia with male flowers only $8 \mathrm{~mm}$. long, stamens half as long.

Loreto: Soledad, Río Itaya, (Tessmann 5256, type). "Shapaja."

Scheelea Tessmannii Burret, Notizbl. Bot. Gart. Berlin 10: 682. 1929.

Trunk 12 meters tall, $5 \mathrm{dm}$. in diameter, the crown with about 15 leaves; spadix about $4.5 \mathrm{dm}$. long, apically attenuate, the male flowers finally in 5 laxly spiralled series, $15-17 \mathrm{~mm}$. long, sepals scarcely $1 \mathrm{~mm}$. long, petals cylindric, $1 \mathrm{~mm}$. thick, stamens shorter than $5 \mathrm{~mm}$.; lower part of branchlets with 12-17 slightly secund female flowers, before anthesis oblong, $2.7 \mathrm{~cm}$. long; sepals oblongacuminate, stigmas included; fruit $8 \mathrm{~cm}$. long, cylindric-terete, $3 \mathrm{~cm}$. in diameter, rather gradually extended about two-thirds its length into a stout beak; mesocarp 2-4 mm. in diameter, endocarp 6-7 mm. thick, minutely fibrous; perianth nearly $2.5 \mathrm{~cm}$. high, sepals and petals subequal, the former ovate-oblong, the latter broadly rounded, both acute.-Fruit recalls that of $S$. kewensis Hook. f. (cf. S. brachyclada) but more slender and stigmas included; also, male flowers spiralled, petals much longer (author). Photograph shows a strong but slender trunk, smooth but annulate, leaf-rachis little arched, leaf-segments on same plane, apparently regularly disposed, the interfoliar spadices about 10.

Loreto: Inundated and non-inundated woods, Iquitos, (Tessmann 5085, type). "Shapuja," "chapaja."

Scheelea Weberbaueri Burret, Notizbl. Bot. Gart. Berlin 10: 659. 1929.

Completely stemless, the leaves 9-10 meters long, the rachis (fragment, probably medial) $3 \mathrm{~cm}$. broad, acutely carinate above, rounded beneath, only dorsally fuscous furfuraceous; segments aggregate, di- 
rection diverse, 4-5 $\mathrm{cm}$. wide, green above, paler beneath, the midnerve stout, longitudinal and transverse nerves obscure or faint both sides; male spadix (flowers unknown) $6 \mathrm{dm}$. long, basal part $14 \mathrm{~cm}$. long, $2 \mathrm{~cm}$. in diameter at apex, rachis glabrous, much attenuate, branchlets slender, very numerous, spiralled, lower flowers in 5-6 series on upper third of rachis approximate, floral bracts minute; fruiting spadix $8 \mathrm{dm}$. long (base $2.5 \mathrm{dm}$. long), upper bracts large; apices of branchlets with sterile male flowers; fruits mostly abnormal, more or less compressed obovoid, 7-9 $\mathrm{cm}$. long (with perianth and beak-this $7 \mathrm{~mm}$. long), about $4-4.5 \mathrm{~cm}$. in diameter, rounded apically; perianth mostly lacerate, $2.5 \mathrm{~cm}$. high, segments rather ovate; mesocarp 2-2.5 mm. thick, outer part finely fibrous, endocarp densely sulcate, 1-2-celled (transversely).

Junín: La Merced, (Weberbauer 1848, type). "Shapaja.”

\section{MAXIMILLIANA Mart.}

Reference: Burret, Notizbl. Bot. Gart. Berlin 10: 689-701. 1929.

Resembles Scheelea in appearance-vegetatively-but the approximate (in circles) male flowers with minute petals equaled or far exceeded by the 6 filaments, the linear anthers affixed at bifid base, pendulous. Female flowers few, much larger, sepals coriaceous, broadly imbricate, petals little longer. Fruit 1-seeded, pointed or one of the rounded lower halves free from fibers (Drude).

Sepals of male flowers about a sixth as long as petals. .M. venatorum. Sepals of male flowers a third as long as petals......M. stenocarpa.

Maximilliana stenocarpa Burret, Notizbl. Bot. Gart. Berlin 10: 696. 1929.

In general similar to $M$. venatorum but leaf-segments probably $16 \mathrm{dm}$. long, $5 \mathrm{~cm}$. wide, little narrowed below, narrowly bidentate apically, midnerve stout above, secondary nerves 6 ; apex of spathe seen strongly compressed, margins rounded, minutely and deciduously furfuraceous; male spadix glabrous (only fragment seen), prominently carinate, bracts $5 \mathrm{~mm}$. long, often dentate at base, acute, perianth $2 \mathrm{~mm}$. long, sepals $0.75 \mathrm{~mm}$. high, ovate, filaments longer than petals, anthers $8 \mathrm{~mm}$. long; female spadix branches about $2 \mathrm{dm}$. long, bracts $1 \mathrm{~cm}$. long, flowers 7-9 inserted on lower two-thirds, elliptic, $1.6 \mathrm{~cm}$. long, sepals ovate, the little longer petals acute, dentate; upper third of branches sterile male flowers, these with suboblong petals, sepals $1 \mathrm{~mm}$. long, anthers $5 \mathrm{~mm}$. long; fruiting 
branches 2; cup of perianth bracts $7 \mathrm{~mm}$. across; fruit $4.5 \mathrm{~cm}$. long, $18 \mathrm{~mm}$. in diameter, deciduously tomentose, sepals ovate, acute, petals rotund, apiculate; mesocarp fleshy, finely fibrous, endocarp smooth, beaked, $4 \times 1.6 \mathrm{~cm}$., the pores about $5 \mathrm{~mm}$. above the base. - Contrasts with $M$. venatorum, as the calyx of male flowers in comparison with petals is several times longer, and the heads of the branches as well as the male flowers are notably longer (author).

Loreto: Iquitos, (Tessmann 5081, type; also 5078, male). "Ynayuca," "inayuca."

Maximilliana venatorum (Poepp.) Wendl. Kerch. Palm. 251. 1878; 698. Cocos venatorum Poepp. ex Mart. Hist. Nat. Palm. 3: 325. 1850. Attalea venatorum (Poepp.) Mart. l.c.

Caudex less than 8 meters high, leaves with long petioles, the 4-aggregate pinnae in part erect, all lepidote at base, linear, longacuminate; spathe pubescent, longitudinally sulcate, long-cuspidate; spadix about $8 \mathrm{dm}$. long, branches of female erect, glaucous-pruinose; stamens 6 , exserted, 4 times longer than the perianth; fruit oval.Burret described the Tessmann specimen about as follows: apical leaf fragment with triangular rachis minutely fuscous scurfy beneath; segments aggregate nearly to apex, the lower variously directed, all rigid, concolor, secondary nerves about 3 , the ulterior obscure above, many very fine beneath, the transverse more prominent above; lower segments seen 3 -aggregate, $7 \mathrm{dm}$. long, $2 \mathrm{~cm}$. wide, the upper mostly binate, the uppermost very narrow; branches male spadix fragment, incrassate at base, 14-16 cm. long, sparsely bracteate to about onethird, finally densely flowered, about $2 \mathrm{~mm}$. thick; floral bracts subrotund, minutely extended, oblong, nearly $7 \mathrm{~cm}$. long; perianth $2.75 \mathrm{~mm}$. high, sepals scarcely $0.5 \mathrm{~mm}$. long, petals narrowly oblong, filaments as long, anthers linear, 7 mm. long. F.M. Neg. 31308.

Indians use petioles as blow-pipes for the arrow poison Urari (Poeppig).

San Martín: Tocache, (Poeppig).-Loreto: Yurimaguas, (Poeppig). Yarina-cocha, (Tessmann 5492). "Ynaynca," "inayuca."

\section{AIPHANES Willd.}

Martinezia R. \& P. Prodr. 148, pl. 32. 1793 (per Dombey, litt.); 1794 (per title); Syst. Veg. 295. 1798, a mixture fide Burret, Repert. Sp. Nov. 34: 169-170. 1933.

Reference: Burret, Notizbl. Bot. Gart. Berlin 11: 557-577. 1932. 
Spiniferous nearly all over, and thus resembling many species of Bactris but the spadices elongate and sooner or later free from the slender or thin, not cymba-like spathe. Pinnae usually cuneatebased, sometimes strongly oblique at the truncate or erose apex. Flowers variously disposed as to sex but ordinarily 1 female with 2 male, now and then the spadix mostly female, not infrequently entirely below. Stamens 6 , linear or suborbicular, the male flowers not immersed. Ovary 3-celled. Fruit a small, 1-seeded, firm or fleshy depressed-globose drupe, the seed rugose or pitted, albumen plane, solid.-A. caryotifolia (HBK.) Wendl., ascribed to Peru by Martius, is probably an error (cf. Burret, l.c. 560); the species, at least as to typical state, is restricted, perhaps, to Colombia or area north of Peru.

Flowers scarcely immersed, male higher than basal, acute; female staminodal cup teeth 6, obvious (subgenus Macroanthera Burret).

Leaf-segments $3-5$-aggregate................... Ernesti.

Leaf-segments distinct................... praemorsa.

Flowers, especially female, more or less immersed; male of ten broader than high, rounded; staminodal teeth obscure or little obvious (subgenus Brachyanthera Burret).

Caulescent.

Leaf pairs $5-12$, cuneate or deltoid leaflets.

Leaflets 5 pairs, small..................... Ulei.

Leaflets 12 pairs, ample................. deltoidea.

Leaf pairs many, narrow.

Leaflets all subequal .................... gracilis.

Leaflets unequal. ..................Weberbaueri.

Acaulescent......................... Tessmannii. 1932.

Cespitose, the larger stems to 2 meters long, regularly spiny as the petioles, these $3.5 \mathrm{dm}$. long, densely fuscous scurfy, not setose, the spines $3 \mathrm{~cm}$. long, black; rachis aculeate, setose and pubescent, beneath furfuraceous; leaves 10 or 12 , about $14 \mathrm{dm}$. long, oblong, the segments around 12 pairs, very unevenly disposed, 2-3-aggregate, widely spaced, the lower above the base mostly 1-aculeate, $4-4.5 \mathrm{~cm}$. long, all above smooth and glabrous, subglabrous beneath, broadly elongate-deltoid-cuneate, the apical decurrent 2-2.5 cm., inner mar- 
gin $2.6 \mathrm{dm}$. long, $8-11 \mathrm{~cm}$. wide, the apex praemorsely obliquely lobulate and caudately produced $6 \mathrm{~cm}$., lower segments shorter but often relatively wider; spadices interfoliar, about 1 meter long, the branched part $47 \mathrm{~cm}$. long; lower spathe linear, about $3 \mathrm{dm}$. long, to $12 \mathrm{~mm}$. wide, furfuraceous, free part $7 \mathrm{dm}$. long, linear, not at all acuminate; peduncle as rachis and many divaricate branches-these slender, flexuose, the lower 3.5, the upper about $1 \mathrm{dm}$. long-furfuraceous, setose and setulose; glomerules mostly 2 males, upper flowers all male, the latter broader than high, sepals oblong, petals broadly ovate, costate, anthers oval; female sepals rotund, petals connate, lobes triangular, staminodal cup obscurely dentate.-Male flowers orange, female more greenish, all odorless; fruit eaten, sweet.

Loreto: Mouth of Río Santiago, (Tessmann 4709, type). "Chiquichiqui," "chica-chica," "shica-shica."

Aiphanes Ernesti Burret, Notizbl. Bot. Gart. Berlin 11: 560 . 1932. Martinezia Ulei Damm. l.c. 6: 266. 1915, not 1907.

Petioles, leaf-rachis and spathes whitish-tomentose, brown-squamate and dark brown aculeate with spines to $3.5 \mathrm{~cm}$. long; leafsegments 3-5-aggregate, elongate-cuneate, to $3.5 \mathrm{dm}$. long, $1 \mathrm{dm}$. wide, apically erosely crenate-dentate and tricuspidate, glabrous above, pubescent beneath, the upper of the sparsely setose margins long-produced; outer spathe membranous toward apex, finally only fibrous, the inner elongate-lanceolate, subligneous, sparsely shortaculeate, to $6 \mathrm{dm}$. long, $3 \mathrm{~cm}$. wide; spadix long-peduncled, branches many to $26 \mathrm{~cm}$. long, $3 \mathrm{~mm}$. thick at base, tortuous, densely flowered; flowers solitary toward apex; male calyx subhyaline, lobes longlanceolate, $1.5 \mathrm{~mm}$. long, corolla fleshy, petals ovate, acuminate, $3 \mathrm{~mm}$. long, $1 \mathrm{~mm}$. wide, those of female cordate, $1.5 \mathrm{~mm}$. long; fruit red.-Type, Alto Acre (Ule 116B, type).

Peru (probably). Adjacent Brazil.

Aiphanes gracilis Burret, Notizbl. Bot. Gart. Berlin 11: 566. 1932.

Similar to A. Weberbaueri, but slenderer and smaller; type half meter tall; petioles about $3 \mathrm{dm}$. long, densely black-setose and -aculeate, the larger spines nearly $4.5 \mathrm{~cm}$. long, these as setae but smaller on the lower part of the leaf-rachis and the leaf-segments beneath; leaf-blades to $9.5 \mathrm{dm}$. long, the 17-20 pairs of segments plicate in the nerves, rigid, the apical 2 subequal or narrower, to about $14 \mathrm{~cm}$. long, the longest about medial, $1.5 \mathrm{dm}$. Iong on midnerve, upper margin 
produced 3-5 cm., to $3.5 \mathrm{~cm}$. wide, upper segments decreasing in size; spadix slender, about $13 \mathrm{dm}$. long, sparsely and minutely blacksetose, the branched part $6 \mathrm{dm}$. long, the branches 12-15, scattered; upper male flowers 2 or solitary.-Except that the terminal leafsegments are little if at all wider than the rest, the differences appear to be relative developments.

Amazonas: Río Mayo north of Moyobamba, (Weberbauer 4665, type; 585).

Aiphanes praemorsa (Poepp.) Burret, Notizbl. Bot. Gart. Berlin 11: 575. 1932. Bactris praemorsa Poepp. ex Mart. Palm. Orbign. 10: 66. 1847 .

Low caudex and basally vaginate petiole aculeate, the smooth leaf-rachis lepidote-tomentose, the few deltoid leaflets apically erosedenticulate, marginally aculeolate, early lepidote beneath, finally green; drupe turbinate-globose.-Seems to differ from A. caryotifolia (HBK.). Wendl. in that the indument and the leaf-rachis are not aculeate, and the segments are larger (Martius). No fruit at Munich, but the leaves most resemble $A$. caryotifolia; the rachis, however, is quite without spines; noteworthy, also, is the white tomentum; in A. Ernesti the lower leaf segments are strongly drawn together (Burret).

San Martín: River woods near Tocache, (Poeppig, type).

Aiphanes Tessmannii Burret, Notizbl. Bot. Gart. Berlin 11: 564. 1932.

Acaulescent; petioles $3 \mathrm{dm}$. long; spines black, few, to $5 \mathrm{~cm}$. long, setae many, yellowish-brown, these also on both sides of leaves and on spadices; leaves long-elliptic, $12 \mathrm{dm}$. long, rachis not at all aculeate, extended as a filum; apical lobes 7-nerved, $11-12.5 \mathrm{~cm}$. across, the inner margin $2 \mathrm{dm}$. long, the apical unevenly lobulate-dentate; remaining segments 1-nerved, 19-20 on each side, rather regularly spaced, mostly the medial larger, these on midrib about $28 \mathrm{~cm}$. long, on upper caudate margin $32 \mathrm{~cm}$. long, all sublinear, $2.5-3 \mathrm{~cm}$. wide, thin, yellowish-green with long rigid trichomes; branched part of spadix $4.5 \mathrm{dm}$. long; peduncle elongate; lower spathe apparently black-setose, the upper very long, thin, narrow, yellowish-setose; branches not aculeate, the setae minute; glomerules rarely with 2 male flowers, the upper with flowers nearly always solitary; petals reflexed, ovate-rounded, nervose, calyx not produced basally, sepals 
suboblong, anthers oval; female flowers with broadly rounded sepals, staminodal teeth obscure.-An outstanding species (author).

Loreto: Mouth of Río Santiago, (Tessmann 4281, type).

Aiphanes Ulei (Damm.) Burret, Notizbl. Bot. Gart. Berlin 11: 568. 1932. Martinezia Ulei Damm. Verh. Bot. Ver. Brandenb. 48: 127. 1907.

Slender, 1-4 meters tall, the pinnate leaves with 5 pairs of cuneatetruncate, setose-ciliate leaflets about $1 \mathrm{~cm}$. distant and a single pair 6-8 $\mathrm{cm}$. from these, the 3 -angled rachis somewhat scaly and strongly black-spiny; leaflets (known) to $6 \mathrm{~cm}$. long, $2 \mathrm{~mm}$. wide at tip, the marginal setae $1 \mathrm{~mm}$. long, $2-4 \mathrm{~mm}$. distant; spadix $3 \mathrm{dm}$. long or longer; peduncle sparsely aculeate; rachis pilosulous or glabrous, elongate branches strict, female flowers on lower third or half, male approximate in 2 series above.

Loreto: Cerro de Escalero, (Ule 6880, type).

Aiphanes Weberbaueri Burret, Notizbl. Bot. Gart. Berlin 11: 565. 1932.

Ascending stems to a meter high, the younger portion longaculeate with dark brown spines, these black on the petioles (fragment seen $3 \mathrm{dm}$. long), many, to $6 \mathrm{~cm}$. long; rachis aculeate, yellowish setulae toward apex, produced into a filum above the bifurcation, longer than 1 meter; apical segments both 5-nerved, the inner margin $7.5 \mathrm{~cm}$. long, at the apex $3.5-6.5 \mathrm{~cm}$. wide, praemorsely denticulate, the remaining 18-20 all 1-nerved, very unevenly disposed in clusters at long intervals, those below the apical somewhat narrower, the larger medial segments about $21 \mathrm{~cm}$. long on the midnerve, $24 \mathrm{~cm}$. on the upper margin, to $4.5 \mathrm{~cm}$. wide above, thin, not at all plicate, green both sides, often beneath above base 1-aculeate, both sides between and on veins short- and long-brownish-setulose, the upper margin (not lower) caudate, the apex unevenly lobulate; spadices rather slender, branched part $42 \mathrm{~cm}$. long, branches about 24 (peduncle sparsely aculeate, setose, $4 \mathrm{dm}$. long), the lower 12 remote, largest seen about $3.5 \mathrm{dm}$. long, rigid, subflexuose, densely brown setose; lower glomerules laxly spiralled, upper and those of upper branchlets male, mostly solitary; petals broadly ovate, obtuse, anthers small, suborbicular; fruits oval, setose, with perianth $12 \mathrm{~mm}$. long, $1 \mathrm{~cm}$. thick, sepals rotund, petals connate below, cup obscurely dentate.

Huánuco: Río Pozuzo, (Weberbauer 6775, type). 


\section{ASTROCARYUM G. F. W. Meyer}

Reference: Burret, Repert. Sp. Nov. 35: 114-158. 1934.

Spinescent and vegetatively similar to Aiphanes-rarely acaulescent, often robust, and, especially, the spathe-valves cymba-like, the peduncles short, extended as the rachis of the reduced spadix, the male immersed in the crowded, usually simple branches. Fruit $1(-2)$ -seeded, the pericarp slightly fleshy but soon dry, fibrous within, the somewhat accrescent perianth persisting, the 3 subapical, often radiately ornamental pores regularly at the same height (Burret); albumen grooved.-Entirely mature fruit with perianth is necessary to determine the species (Burret).

Spadix branches with 2-many female flowers laxly disposed above base; fruit not long-cuneate or applanate, not aculeate or setose (subgenus Pleiogynanthus Burret).

Fruit early scurfy and setulose; staminodal cup elongate.

A. chambira.

Fruit glabrous; staminodal cup short.

Leaf-segments $3-4$-aggregate............. tucuma.

Leaf-segments equidistant................... jauari.

Spadix branches with 1 female flower, basal or subbasal; endocarp normally cuneate below, often laterally somewhat prismatically applanate, mostly aculeate or setose (subgenus Monogynanthus Burret).

Calyx and corolla of female flowers subequal.

Plants acaulescent. A. huicungo.

Plants caulescent. ................... murumura.

Calyx shorter than corolla in female flowers.

Fruit finely setulose; female calyx setose.......A. macrocalyx. Fruit smooth; female calyx esetulose............ chonta.

Astrocaryum chambira Burret, Repert. Sp. Nov. 35: 122.1934.

Caudex solitary, $3.5 \mathrm{dm}$. in diameter, annulate, the internodal spines to $9 \mathrm{~cm}$. long; leaves 16 , about 6 meters long, petioles deeply canaliculate, $1 \mathrm{dm}$. wide, spines to $1 \mathrm{dm}$. long or longer, rachis aculeate and setose; segments many, more or less approximate and unevenly disposed, the linear basal not at all reduplicate, the apical rather abruptly contracted, bifid, mostly subobtuse, the remaining similar but gradually attenuate, all lustrous above, smooth, marginally rather coarsely setose (-ciliate), opaque (probably early silvery) 
beneath, the midrib prominent on both sides, the secondary nerves obscure above, more obvious beneath; upper spathe (fragmentary) a meter long, furfuraceous, aculei slender, $2-2.5 \mathrm{~cm}$. long, not covered by the dense setosity; peduncle $12 \mathrm{~cm}$. long, shortly aculeate, early tomentose and sparsely aculeate, the many branches spiralled, to $4.5 \mathrm{dm}$. long, female flowers bright brown, 2-3 on the lower half of the branch, the upper part a thick, densely white-villous bracted spike of male chocolate-colored blossoms; female with 2 rudimentary male, calyx glabrate, cupulate, little or not longer than the similar but contracted corolla, this white-furfuraceous and black-setulose, nearly equaled by the staminodal cup; male calyx lobes narrowly lanceolate, acuminate, the corolla base connately stiped, the oblong lobes nearly as long; anthers linear, $3 \mathrm{~mm}$. long; fruit elongate- or obovoid-globose, to $7 \mathrm{~cm}$. long including beak (1 cm. long) and cupulate perianth (13 $\mathrm{mm}$. long), $4 \mathrm{~cm}$. in diameter or more; epicarp early scurfy and black-setulose, finally opaque, densely gibbous, mesocarp fibrous, endocarp obovoid, notably produced at base, the calyx more or less damaged, the corolla nearly crenulate.-Distinguished from A. tucuma Mart. by the coniform fruiting perianth and the very high staminodal cup of the female flowers; $A$. macrocarpum Huber (Bull. Herb. Boiss. sér. 2, 6: 271, pl. 13. 1906), of adjacent Brazil, scarcely described, has about 6 leaves, rather weak spines, lower internodes at least twice longer than broad, fruit larger.

Tessmann noted usual uses for similar palms, including the fiber and fruits, and observed this species frequently in areas rarely flooded near Iquitos, on the Ucayali, Tamaya, Yarina-cocha, mouth of the Santiago, and Río Chambira.

This may be the species referred to by Spruce (Journ. Linn. Soc. 11: 157. 1871) as $A$. vulgare Mart. under the same native name, a species not, apparently, within the range; this native name has been listed, as by Dahlgren, also for A. tucuma Mart.; Drude's illustration of the fruit of the latter could be this species (Burret).

San Martín: Tarapoto, (Raimondi).-Loreto: Flood-free area near Iquitos, (Tessmann 5079, type). Brazil. "Chambira."

Astrocaryum chonta Orbigny ex Mart. Palm. Orbign. 10: 84, pl. 4, figs. 1, 2; pl. 29C. 1847; 149.

Caudex at least above long-aculeate, to 10 meters tall; leaves 9-12, finally divaricate, 6 or 7 meters long, $2-5$ meters wide, the linear-acuminate subfalcate pinnae 1 meter long or longer, to $7.5 \mathrm{~cm}$. wide, regularly subopposite, about $2.5 \mathrm{~cm}$. distant, not at all plicate, 
pale or silvery-tomentose beneath, the rachis (this tomentose) and margins black setulose, the spines about 1-2.5 cm. long; midnerve prominent above, the secondary many, very fine, approximate; spathe fusiform, $9 \mathrm{dm}$. long, violet-tinged, closely black aculeate especially toward the apex; spadix branches many, 7-10 dm. long; female flowers subsessile, at base of each branch, calyx as corolla cupulate, the latter 2 times longer, esetulose; male flowers shortly pedicellate, calyx segments acute, carinate, the corolla divisions 4 times higher, oblong-linear, obtuse, the filaments 6 , basally cohering; fruit yellow, long-obovoid, smooth, 6-7 cm. long, scarcely $2.5 \mathrm{~cm}$. thick above, the residual stigmas apical, the pores subapical; black seed radiately veined.-After Martius (1.c. 85), who referred here a fruiting specimen (Herb. Parker Webb) labeled as collected by Pavón, not seen by Burret; however, as it is known from the upper Río Purus it well may occur in flooded woods and shores in Madre de Dios. Plate 29 (l.c.) is incorrect in irregular pinnae; fruit perianth schematic (Burret).

Wood hard but fragile; putamen very sweet (but not eaten) fruit used as a fire-starter (D’Orbigny).

Peru (perhaps). Bolivia; Amazonian Brazil. "Chonta."

Astrocaryum huicungo Damm. ex Burret, Repert. Sp. Nov. 35: 146. 1934.

Acaulescent; leaf rachis medially 3 -angled, early furfuraceous beneath, densely aculeate; segments many, regularly disposed, longlinear, abruptly contracted at base, about $3 \mathrm{~cm}$. wide, smooth, glabrous, blue-green (glaucous) beneath, marginally spinulose toward apex; spadix (branched part) nearly $2.5 \mathrm{dm}$. long, the many branches as the rachis aculeate, the male spikes rather long; fruits compactly crowded, thus laterally somewhat prismatic, cuneate below, mostly oblong-obovoid, verruculose and short-setulose, 5-8 cm. long, rounded to the short cusp; fruiting perianth $2-2.5 \mathrm{~cm}$. high, calyx to threefourths, staminodal cup to two-thirds as high as corolla, both calyx and corolla long-setulose-hirsute; mesocarp apparently not at all fleshy, dry.-Resembles A. jauarense Trail ex Drude (Mart. Fl. Bras. 3 , pt. 2: 372. 1881), with long bracts at the female flowers (no trace of these found on this fruiting specimen); also the setae on the fruits of Trail's species are $1 \mathrm{~cm}$. long (Burret); A. Ulei Burret (l.c. 147) from Río Acre is also acaulescent but the glabrous female calyx is much shorter than the corolla and also suggests the caulescent A. murumura with subequal calyx and corolla, the latter setulose. 
San Martín: Moyobamba, 800 meters, (Weberbauer, type; 147). "Huicungo."

Astrocaryum jauari Mart. Hist. Nat. Palm. 2: 76, pls. 52, 65, fig. 1. 1823 (Burret), 1824 (Dahlgren); 125.

Sometimes 14 meters tall, the spiny zones $3-5 \mathrm{~cm}$. long; leaves about 3 meters long, the short petioles and costa below densely rufous tomentose and spinescent; segments linear, long-acuminate, equidistant, arcuate-pendulous from conduplicate base, 7-8 dm. long, remotely aculeate marginally, silvery beneath; spadix nearly 1 meter long, hidden among the leaves; peduncle white tomentose, erect, $4 \mathrm{dm}$. long, branches many, 3-4 dm. long, rachis tomentulose; spathe ventricose, acuminate, fuscous tomentose and aculeate; scrobiculi of 3-6 flowers 2-3 cm. distant, a single female (glabrous, ciliate as the subequal corolla) with 2 often rudimentary male, this lower part finally equaled by the thick upper spike ( $1.5 \mathrm{dm}$. long) of cuspidately bracted immersed male flowers; stamens included, disk fleshy, calyx as the one-third to one-half longer corolla, 3-parted; fruit insipid, glabrous, greenish-yellow, obovoid, shortly acuminate, $4-5 \mathrm{~cm}$. long, $2.5-3 \mathrm{~cm}$. in diameter, putamen $3-3.5 \mathrm{~cm}$. long, 2-2.5 cm. in diameter, the slender black fibers subparallel.-Inundated areas, forming the "jauary woods" (Huber). Illustrated, Wallace, Palms Amazon, pl. 42 .

Loreto: Soledad, lower Río Itaya, (Tessmann 5210). Amazonian Brazil. "Huirirma," "jauari" (Brazil).

Astrocaryum macrocalyx Burret, Repert. Sp. Nov. 35: 150. 1934.

Low, perhaps to 9 meters tall, the caudex $2.5 \mathrm{dm}$. in diameter with 15 leaves (Tessmann); leaf-rachis narrowly 3 -angled, setulose and aculeate beneath, the segments regularly disposed, not reduplicate, the lower (as seen) $6 \mathrm{dm}$. long, $5 \mathrm{~cm}$. wide, the upper gradually wider, all with secondary nerves not at all plicate, fragile, smooth except marginally spinulose, lustrous above, paler but scarcely silvery beneath; upper spathe (apical part) $6 \mathrm{dm}$. long, fuscous setosevelutinous and aculeate; peduncle spadix to $2 \mathrm{~cm}$. long, aculeate, pilose, the bracts oblong or lanceolate, the branched part $4 \mathrm{dm}$. long, aculei or setae lacking, branches many; female flowers at base of each branch 1 , sessile, the bract little produced, covered by the trichomes and setae of the truncate calyx, the longer corolla narrowed above, furfuraceous and densely black-setulose as the pistil, staminodal an- 
nulus present; male flowers all fertile (spikes pedunculate, yellowishpilose), in 6 vertical series, calyx small, narrowly 3-denticulate, petals obovate, cucullate; fruits (by mutual pressure) prismatic below, obovoid-oblong, $6.5-8 \mathrm{~cm}$. long (beak $5 \mathrm{~mm}$. long), finely setulose; perianth $1.8 \mathrm{~cm}$. high, calyx half as long as corolla, both setulose, mesocarp more or less reticulate fibrous.-Resembles $A$. murumura Mart. with calyx and corolla of female flowers subequal. A. urostachys Burret (1.c. 151), of Río Napo, Ecuador, so probably also in Peru, has peduncles without aculei or setae, and rudimentary flowers at the ends of the male spikes.

Loreto: On the Marañón, (Hopp 1126, type). Iquitos, (Tessmann 511\%, probably; Burret). "Huicungo" (Tessmann).

Astrocaryum murumura Mart. Hist. Nat. Palm. 2: 70, pls. 58, 59. $1823 ; 148$.

Caudex rarely attains 6 meters, $2.5 \mathrm{dm}$. in diameter, the coma globose with a mixture of leaves, sheath remains and spines often several to $10 \mathrm{dm}$. long; petioles aculeate, leaves 3-4 meters long, segments $30-40$ or more both sides, unequally distant, linear-lanceolate, falcate-acuminate, about $5 \mathrm{dm}$. long, half as wide, mostly unevenly floccose-tomentose below, secondary nerves mostly 3 , very prominent; spadix about 1 meter long, the long peduncle tomentose and aculeate, the upper spathe fuscous setose and aculeate, rachis $1 \mathrm{dm}$. long, branches 200 or so, 1-1.5 dm. long, pedicels $3-4 \mathrm{~cm}$. long; male flowers $3 \mathrm{~mm}$. long, half emerged, turbinate-obovoid; female on dilated base of branches, $1 \mathrm{~cm}$. high, $6 \mathrm{~mm}$. across, calyx glabrescent, about equaled by the campanulate setose corolla; stigmas elongate, exserted; fruit 5-6 cm. long, $4 \mathrm{~cm}$. in diameter above the middle, sparsely setulose, putamen turbinate-obovoid, arcuately lined and coarsely stellate a little below the acute apex.-After Drude. Said by Spruce (Journ. Linn. Soc. 11: 157. 1871) to grow along the Huallaga to the foot of the Andes, and by Huber (Bull. Herb. Boiss. sér. 2, $6: 267.1906)$ to be found in nearly all the Amazonian region, including the upper Purus, at the edge of flooded zones; not included in Peru, however, by Burret. F.M. Negs. 18572; $18572 a$.

Peru (cf. above). Amazonian Brazil. "Huicungá," "uicungu," "murumura" (Martius).

Astrocaryum tucuma Mart. Hist. Nat. Palm. 2: 77, $p l .65$, fig. 2. 1823; 119. A. princeps Barb. Rodr. Enum. Palm. 22. 1875, fide Burret. 
Caudex 15 meters tall or taller, the spreading spines $1 \mathrm{dm}$. long; spathes at insertion strongly tumid, spinescent, the 8-12 (or more?) leaves 2-3 meters long, segments 3-4-aggregate, costa aculeate, whitish-tomentose beneath, setae ciliate, linear-acuminate, 6-8 dm. long, 3-4 cm. wide; spadix 1.5 meters long, spathe smooth below, aculeate toward long-acuminate tip, rachis smooth, branches slender, finely tomentulose, 400-500, erect, 2.5-3 dm. long; female flowers at nearly $1 \mathrm{dm}$. from base, the lageniform setulose calyx deeply parted, subequaling the glabrous corolla, scarcely $1 \mathrm{~cm}$. long, the staminodal cup less than half as long; male flowers immersed, minutely bracteolate, calyx minute, 4-5 times shorter than corolla; fruit glabrous, putamen acute at base, obovoid, rostrate.-Included by Dahlgren in his list but possibly replaced entirely within Peru by similar species as $A$. chambira Burret, which compare, but may be known as near as Ríos Solimöes and Japurá (Burret).

Peru (perhaps). Amazonian Brazil.

\section{BACTRIS Jacquin}

Guilielma Mart. Palm. Fam. 21. 1824. Pyrenoglyphis Karst. Fl. 2: 141. 1866. Martinezia R. \& P. Prodr. Fl. Peruv. 148, pl. 32. 1794, in part. Amylocarpus Barb. Rodr. Contr. Journ. Bot. Río Janiero 3: 69. 1902, fide Burret, l.c. 168. Yuba (Barb. Rodr.) Bailey, Gentes Herb. 7: 416. 1947, not Amylocarpus Currey, 1857.

Reference: Burret, Repert. Sp. Nov. 34: 167-253. 1934.

Strikingly to inconspicuously spinescent (rarely not at all), usually clustered (cespitose), the straight annulate commonly slender trunks rather rarely very tall. Leaves sometimes in part subterminal, simple, bifurcate or pinnate, the often many segments attenuateacuminate, characteristically more or less ciliate, at least at tip. Spathes cymbiform, ordinarily firm-chartaceous (sometimes lignescent), the inner exceeding the entire spadix, this interfoliar, simple or once-branched, its peduncle often soon divaricate or pendulous. Flowers sessile, monoecious in same spadix, typically on the female scattered or the sexes intermixed or the lower ternate, the central female; stamens 6, 9 or 12, filaments subulate and long (known), the erect bifid anthers affixed at bifid base, calyx annular, urceolate or 3-parted; female calyx similarly varies, about half to nearly completely enclosing the 3-denticulate corolla, the staminodia obsolete or free or infrequently (subgenus Pyrenoglyphis) forming a ring; 
ovary 3-celled. Fruit 1-celled, 1-seeded, ovoid-subglobose, sometimes suboblong, stigmas sessile, terminal, pericarp slightly to very succulent, endocarp osseous, more or less subapically 3-pored, seed pendulous, raphe reticulate, albumen uniform.-Subgenus Guilielma has no staminal cup, and the leaf-segments are usually in more than one plane (Bailey), but extraordinarily characteristic are the flat band-like fibers radiating from the pores of the endocarp (Burret); this is usually uniformly covered with fibrous or other tissues (as prickles). The fruiting perianth may be somewhat accrescent, indurated, forming a double merely crenate or entire cup but, especially in Pyrenoglyphis, it is scalloped and shallow (Bailey). As to Pyrenoglyphis, fide Burret, no intermediates as regards the development of the staminodal ring were observed and he therefore retains the genus; practically, this single difference may be regarded as defining a subgenus and still indicate the relationships. Finally, there is the segregate Amylocarpus (Yuba). Bailey (l.c.) implied but did not add basic information to justify acceptance of Burret's considered judgment that the group more correctly is treated as a subgenus, having no distinctive fruit character, but (as redefined by Burret) including species with lower flowers 3-glomerulate, the upper only male, no female; this able and thoughtful student noted that the floral position is too variable within the genus to define, in itself, generic lines.

Burret, who devised no key himself (1.c.), remarked that Drude's key to the Brazilian species is quite unnatural; the following, compiled from literature only, is entirely expedient.

Staminodial ring more or less developed (subgenus Pyrenoglyphis).

Spines pale; leaf-segments to $6 \mathrm{dm}$. long; spadix branched.

B. Brongnartii.

Spines black; leaf-segments to $4 \mathrm{dm}$. long; spadix simple.

B. concinna.

Staminodial ring obsolete, staminodia free (Bactris).

Endocarp fibers radiate in flat bands from pores (Burret); leaves strongly crisped; fruit colored, edible (subgenus Guilielma).

Upper spathe sparsely brownish aculeate; spadix branches 10-12. B. gasipaes.

Upper spathe densely long black aculeate; spadix branches few. B. ciliata.

Endocarp (known) not fibrous as above; leaves and (or) fruits also different (apparently, ex char.). 
Flowers of lower rachis or its branches typically or usually all ternate, 1 male, upper all single, male (subgenus Amylocarpus; see also B. Lakoi).

Calyx (female) as subincluded glabrous corolla cupulate or subcylindric, in fruit subequal; spathes smooth, spadix small, not setose.

Primary nerves 9 or 10 ; spadix simple.

Leaves deeply bifurcate, glabrous.........B. Killipii.

Leaves submedially bifurcate, apex setulose...B. naevia.

Primary nerves 14; spadix bifurcate.........B. amoena.

Calyx (also fruiting) low, 3-lobed, corolla much longer, pilose, cylindric; upper spathes setose or aculeate.

Leaves shortly bifid.................... Birta. Leaves pinnate.

Leaf-segments 10 pairs or fewer, setose-ciliate.

Segments narrowly lanceolate..........B. cuspidata. Segments oblong-lanceolate................ B. mitis.

Leaf-segments many................... B. Lakoi.

Flowers not so regularly disposed by sex, usually 2 male with 1 female, and single females also scattered; sometimes (as $B$. Lakoi) single, or several male may occur between the ternate groups (Bactris sens. str.).

Leaf-segments few or leaves merely parted.

Spadix simple; fruit glabrous........... angustifolia. Spadix few-branched.

Petioles $3 \mathrm{dm}$. long, long-spinescent; fruit glabrous.

B. fissifrons.

Petioles 1-5 cm. long, aculeate; fruit setose.

B. trichospatha.

Leaf-segments many.

Segments linear, about $12 \mathrm{~mm}$. wide........... B. Lakoi. Segments 2-7 cm. wide.

Many segments $3-4 \mathrm{~cm}$. wide or wider.

Leaves beneath, spathes tomentose...B. trichospatha. Leaves green, margins setulose.

Petioles to $5 \mathrm{dm}$. long, setulose, spiny.

B. chaetochlamys. 
Petioles 6-9 cm. long, finally smooth.

B. actinoneura.

Many segments 2-2.5 cm. wide or narrower, if linear, not narrowly.

Spines black; leaves glabrous above, bidentate.

B. riparia.

Spines yellowish; leaves green both sides, acuminate.

$B$. chloracantha.

Bactris actinoneura Drude \& Trail, ex Drude in Mart. Fl. Bras. 3, pt. 2: 344, pl. 76. 1882; 211.

Caudices 2 or 3, a meter or two (-3) high, 2-3 cm. thick, annulate, the spines black, compressed (as on sheaths), 2-3 cm. long; leaves about 8, 2.5-3 meters long, equally pinnate, sheaths 4-5 dm. long, petioles slender, 6-9 $\mathrm{cm}$. long and, as costa, finally smooth; segments 20-25 each side, unevenly disposed, sometimes binate, sessile, broadly ovate-arcuate, strongly falcate-acuminate, rather abruptly caudate, 2-3 dm. long, 4-7 cm. wide, smooth, multinerved, one prominent above, the 14-16 secondary radiating from base, many confluent at tip, obscurely or not setulose on margins; spadix nutant, about $2 \mathrm{dm}$. long, spathe shorter, densely black-aculeate; peduncles scarcely setulose, rachis $2 \mathrm{~cm}$. long, the 6-12 branches slender, 8-12 cm. long, female flowers to above the middle, approximate, esetulose, after anthesis $5 \mathrm{~mm}$. long, calyx 3-lobed, glabrous, corolla twice as long, urceolate, 3-dentate; male flowers and fruit unknown.-F.M. Neg. 18601.

San Martín: Tocache, (Poeppig).-Loreto: Yurimaguas, (Poeppig 2072). Amazonian Brazil.

Bactris amoena Burret, Repert. Sp. Nov. 34: 180. 1933.

Type solitary, $1 \mathrm{~cm}$. in diameter, internodes 11-14 cm. long; petioles $2.5 \mathrm{dm}$. long, rather stout, quite smooth as the sheath-this fuscous furfuraceous, apex broadly ovate-produced-and the simple leaf-blade, not medially bifurcate; leaves obovate, cuneate to base, primary nerves 14 , slender, glabrous both sides, about $5.5 \mathrm{dm}$. long, $3.5 \mathrm{dm}$. wide, the lobes subovate, shortly incurved-acuminate, $27 \mathrm{~cm}$. long (on upper margin); spadix bifurcate, smooth as the fragmentary spathe; free part of fruiting peduncle $2 \mathrm{~cm}$. long, recurved, branches 5-6 cm. long, 3-flowered glomerules to apices, not alveolate, densely spiralled; fruit smooth, ovoid, robustly rostrate, $7 \mathrm{~mm}$. wide, $12 \mathrm{~mm}$. 
high, with perianth, this cupuliform, $3 \mathrm{~mm}$. high, the 3-lobed calyx two-thirds as long as the 3 -lobed corolla.-Suggests $B$. simplex Burret (l.c. 179), with 10 primary nerves and aculeate petioles $13 \mathrm{~cm}$. long; less, $B$. integrifolia Wallace, abundantly spinescent (author); species range of variation is of course unknown; it also simulates $B$. bifida Mart. (Pyrenoglyphis, fide Burret). Type from Río Putumayo (Río Ica) on the boundary (Lako 4).

Peru (no doubt). Adjacent Colombia or Brazil.

Bactris angustifolia Damm. Verh. Bot. Ver. Brandenb. 48:128. 1906 (-7); 201.

Type a meter or two high, the simple leaves with spiny petioles 10-13 cm. long (spines few, to $6 \mathrm{~cm}$. long, brown); sheath fibrous; rachis to $22 \mathrm{~cm}$. long, blade medially bifid, $48 \mathrm{~cm}$. long, $7 \mathrm{~cm}$. wide, cuneate, 8-nerved each side, the apical, little divaricate lanceolate lobes $2.5 \mathrm{dm}$. long, $4 \mathrm{~cm}$. wide, attenuate to base, marginally aculeate; lower spathe fusiform, the appressed aculei brown, 2-3 $\mathrm{mm}$. long; peduncle 7-8 cm. long, 2 apical branches $3.5-6 \mathrm{~cm}$.; flowers approximate (injured); fruits black.-B. sphaerocarpa Trail, 201, with leaves more than medially bifid or biparted, the lobes basally linear-lanceolate, 6-8-nerved, and widely known rather near Peru, may occur there; type of Dammer's species from headwaters of the Río Juruá, near the boundary, may be a variant.

Peru (undoubtedly). Adjacent Brazil.

Bactris Brongnartii Mart. Palm. Orbign. 59. pl. 7, figs. 2, $28 A$. 1847 (fig. 2 under name $B$. maraja); 251. Pyrenoglyphis Brongnartii (Mart.) Burret, Repert. Sp. Nov. 35: 251. 1934. B. maraja Mart. Hist. Nat. Palm. 2: 93, pl. 71, fig. 1. 1823 as to fruiting spadix, name probably based on a mixture (Burret). B. rivularis Barb. Rodr. Enum. Palm. 36. 1875.

Stems usually clustered, rarely 10 meters tall, cylindric or constricted at the nodes, the internodes stouter above, unequal in length and in the upper part densely aculeate, the spines pale, divaricate; petioles, spathes and leaf-rachis also whitish-aculeate; leaves crowded, 9-12, somewhat crisped, adult spreading, 3-4 meters long, segments to nearly $6 \mathrm{dm}$. long, $3 \mathrm{~cm}$. or so wide, lanceolate, acute, marginally rather long-aculeate, duplicate; spadix branched, early included in the fusiform spathe, $3 \mathrm{dm}$. long, densely and shortly aculeate; calyx of female flowers shorter than $5 \mathrm{~mm}$., the oblong-cylindric corolla 
included, minutely pubescent; fruit turbinate or obovate-globose, shortly cusped, $14 \mathrm{~mm}$. in diameter, violet-black, fleshy, acid; putamen depressed globose or lenticular, 3-pored.-Illustrated, Barb. Rodr. Sert. Palm. Bras. 2: pls. 30, 31 (B. rivularis).

Loreto: Inundated terrain, Cashiba Playa, (Tessmann 3267). Edge of Río Itaya near Iquitos, (Tessmann 5086). Bolivia; Brazil. "Chontilla," "nieja," "niejilla," "tana," (all Tessmann).

Bactris chaetochlamys Burret, Repert. Sp. Nov. 34: 208. 1934.

Caudex (type) to $5 \mathrm{~cm}$. in diameter; sheaths as petioles-these to $5 \mathrm{dm}$. long-fuscous furfuraceous, minutely black setulose and aculeate with rather dilated spines, to $4 \mathrm{~cm}$. long, nearly subulate, to $7 \mathrm{~cm}$. long on the petioles; rachis $11 \mathrm{dm}$. long, furfuraceous beneath, minutely more or less darker setulose all over; segments 20-22, only the upper rather regularly disposed, a few of the remaining aggregate, the larger $3.5 \mathrm{dm}$. long, $4 \mathrm{~cm}$. wide, all thin, lightly but clearly sigmoid, green both sides, glabrous but marginally setose-ciliate, obscurely bidentate, the upper part narrowly caudate, the lower obscure; peduncle compressed, $1.5 \mathrm{dm}$. long, velvety setulose as the $2.5 \mathrm{~cm}$. long rachis; branches about 8; male flowers crowded, disposed all over, as the scattered female; fruit glabrous, to $2 \mathrm{~cm}$. long, $17 \mathrm{~mm}$. in diameter, cusp $1.5 \mathrm{~mm}$. long, perianth $3 \mathrm{~mm}$. high, calyx striate, fuscous setose, as the little longer corolla (about $2 \mathrm{~mm}$. long), at last medially multilobed; putamen subglobose; staminodal cup none.No doubt the upper spathe has the indument of the peduncle; notable are the long thick serpent-like setae of the perianth (author). Type from upper Río Napo near the boundary with Peru.

Loreto (surely). Amazonian Ecuador.

Bactris chloracantha Poeppig ex Mart. Hist. Nat. Palm. 2: 145. 1837; 234; 346 (Drude).

Clustered (cespitose) stems about 2 meters tall, $8 \mathrm{~cm}$. in diameter, more or less aculeate with straw-colored subterete spines, especially abundant on the sheaths and petioles, the latter also white-floccose, $3-5 \mathrm{~cm}$. long; leaves equally pinnate, 6-9 dm. long, the segments 2-5-aggregate, many, linear-oblanceolate, long-acuminate, caudate, 2-2.5 dm. long, 2-2.5 cm. wide, green both sides, margins setulose; spadix $2 \mathrm{dm}$. long or longer, slender (upper spathe aculeate, Martius), peduncle compressed, $2-3 \mathrm{~cm}$. long, branches about 12 , a $\mathrm{dm}$. or so long, floriferous to base; female flowers few, disposed to above the middle of the branches, $5-6 \mathrm{~mm}$. long, the urceolate corolla at least 
twice longer than calyx, glabrous; fruit ovoid, acute, glabrous, dark violet.-F.M. Neg. 18606.

Loreto: Yurimaguas, (Poeppig 210\%, type). Brazil. "Cachirana," "caxirama."

Bactris ciliata (R. \& P.) Mart. Hist. Nat. Palm. 2: 95, pl. 71. 1823. Martinezia ciliata R. \& P. Syst. Veg. 295. 1798. Guilielma ciliata (R. \& P.) Wendl. Kerch. Palm. 246. 1878; 240.

Tall, the trunks and leaf-rachises aculeate and hirsute with spreading white trichomes; leaf-segments equidistant, linear-lanceolate, long-acuminate, to $4 \mathrm{dm}$. long, about $3 \mathrm{~cm}$. wide, marginally and midnerves above setose-aculeate, hirtellous below, the midnerve prominent above, not decurrent, the secondary and tertiary strongly approximate, glabrate only above; spathe $4 \mathrm{dm}$. long or longer (terete acumen about $12 \mathrm{~mm}$. long), early fusiform, lignescent, completely covered with setiform aculei $12 \mathrm{~mm}$. long, more robust on the anterior part and imbricate, like an animal pelt, but toward apex of spathe the covering spreading and reversed; spadix branched; fruit obovoidoblong, putamen obovoid (Martius). - This palm has the trunk covered with long black sharp spines; its wood is black on the exterior, solid, and very hard; nevertheless, it is easy to work lengthwise so that the Indians use it for bows, arrow points, canes and blow-pipes, beautifully polished; shoots are tasty, raw or cooked (Ruiz \& Pavón). The upper spathe is covered with long black prickles; the spadix with young flowers is very small and has only a few branches (Burret, after the type). Burret adds that the species is rather near G. gasipaes (HBK.) Bailey.

Huánuco: Pozuzo, Cuchero, (Ruiz \& Pavón, type).-Junín: Chanchamayo, Huabal, (Ruiz \& Pavón). "Chonta."

Bactris concinna Mart. Hist. Nat. Palm. 2: 99, pl. 72, figs. 4-6. 1823; 242; 335 (Drude). Pyrenoglyphis concinna (Mart.) Burret, Repert. Sp. Nov. 34: 242. 1934.

Gregarious, several meters tall, the stem about $2 \mathrm{~cm}$. in diameter, remotely annulate, aculeate above (as petioles) with subulate-compressed black spines 2-3 cm. long; leaves $1.5-2 \mathrm{~mm}$. long, petioles 2-3 dm. long, rachis less spiny, toward apex smooth; segments 30-40 each side, mostly $3 \mathrm{~cm}$. distant, often alternate, linear-lanceolate, the longer lower 3-4 dm. long, to $2 \mathrm{dm}$. long toward apex, $1.5-2 \mathrm{~cm}$. wide, acute or the lower margin caudate, 1-nerved, the margins black 
ciliate; spadix stout, simple, finally nutant, long peduncle compressed, the lower spathe membranous, ferrugineous, $5 \mathrm{~cm}$. long, the upper cylindric-clavate acuminate, nearly $2 \mathrm{dm}$. long, finely black setose and aculeate; rachis shorter than peduncle, male flowers congested, surrounded by female on lower half, these 3-4 mm. long, urceolate setulose calyx little longer than the hirsutulous corolla, staminodal cup present; fruits many, lustrous, dark violet, ellipsoid-obovoid, by pressure sometimes angled, $2-3 \mathrm{~cm}$. long, half as thick, putamen scarcely $1 \mathrm{~mm}$. thick, 3 stellate pores medial or a little above the middle.-B. aristata Mart. ( $P$. aristata Burret, 242), perhaps occurring, has fewer leaf-segments, rachis of spadix mostly biparted, setose corolla 2-3 times longer than calyx (female), fruit glabrous. Another upper Amazon species is B. gaviona Trail ( $P$. gaviona (Trail) Burret, 246 ), the 30-35 segments equal, the peduncle stout with 4 long branches, the female corolla 2-3 times longer than calyx, inflated, the fruit setose-scabrous. Spruce (Journ. Linn. Soc. 11: 147. 1871) treated B. concinna Mart. as a subgroup (Endochlamys). Illustrated, Mart. Fl. Bras. 3, pt. 2: pl. 78, fig. 1; Barb. Rodr. Sert. Palm. Bras. 2: pl. $3 B$. Wood used in making weapons (Tessmann). F.M. Negs. $18609 ; 18610$.

Loreto: Among shrubs of shores and flooded terrain, (Tessmann 3263). To Colombia and Amazonian Brazil. "Niejilla."

Bactris cuspidata Mart. Hist. Nat. Palm. 2: 101, pl. 73B, figs. 1, 2. 1823; 185.

Stem scarcely $5 \mathrm{~mm}$. thick, smooth, glabrous below, fuscous tomentose above; leaves 4 or 5, mostly 6-7 dm. long, sheath and petiole aculeate (spines dark, 5-10 mm. long), costa smooth, $3 \mathrm{dm}$. long, the segments 5-8 pairs, narrowly falcate-lanceolate, caudately acuminate, 1-1.5 dm. long, 2.5-3 cm. wide, 1-nerved, secondary nerves many, prominent, glabrous except for the sparsely setose margins and nerves or rarely setulose beneath; spathe sparsely long-setose; spadix below the leaves, erect, $6 \mathrm{~cm}$. long, peduncle hidden in sheath and spathe, rachis (about $3 \mathrm{dm}$. long) divided into 2 or 3 branches; upper spathe about $6 \mathrm{~cm}$. long, fusiform, coriaceous, tomentose and early capillaceously setulose; female calyx annulate, 3-lenticulate, corolla 3 times longer, hirsutulous.-According to Burret the var. mitis of Drude (not Mart.) is B. ucupensis Spruce (Journ. Linn. Soc. 15: 150. 1871), calyx higher, spathe not setulose; perhaps, as suggested by Burret, is a variant; like B. cuspidata and B. mitis Mart. known from western Amazonian Brazil so may well occur in Peru. 
Type from Ríos Yapura and Solimöes, so probably, as listed by Dahlgren, in Peru. F.M. Neg. 18611.

Peru (cf. note). Brazil.

Bactris fissifrons Mart. Hist. Nat. Palm. 2: 103, pl. 73B, figs. 3, 4. 1823; 202; 327 (Drude).

Stem unarmed, 2-3 meters tall, 1-2 cm. in diameter, vaginate above; petioles slender, about $3 \mathrm{dm}$. long, spinescent above with black teeth, aculei $1-1.5 \mathrm{~cm}$. long, leaf rachis $4 \mathrm{dm}$. long, smooth as the 2-4 segments, the upper broadest, multinerved, marginally blacksetose; peduncle nutant, upper spathe fusiform-acuminate, aculei $1 \mathrm{~cm}$. long, appressed, black, finally deciduous; spadix $2 \mathrm{dm}$. long or longer, branches 2-4, fastigiate (rachis obsolete), spreading, densely flowered to base; female flowers (male unknown) 4-5 mm. long, calyx cupulate, $2 \mathrm{~mm}$. long, corolla appressed setulose, twice as long; fruit ellipsoid, mucronate-rostrate ( $5 \mathrm{~mm}$. long), glabrous, $2.5 \mathrm{~cm}$. long, $1.5 \mathrm{~cm}$. in diameter, putamen depressed gibbous-turbinate. - B. sphaerocarpa Trail (Journ. Bot. 15: 8, pl. 184. 1877; Fl. Bras. 325), widely distributed near Peru, has sheath and petioles aculeate or smooth, leaves simple and usually deeply bifid or with 1 opposite pair of segments, spadix simple, short-cylindric, calyx as longer corolla glabrous or ciliate, in fruit lacerate; said by the author to be variable; Dammer proposed another, possibly distinct, as $B$. angustifolia (Verh. Bot. Ver. Brandenb. 48: 128. 1906 [-7). F.M. Neg. 18612.

Peru (no doubt). Adjacent Brazil; Colombia.

Bactris gasipaes HBK. Nov. Gen. \& Sp. 1: 302.1815. Guilielma gasipaes (HBK.) Bailey, Gentes Herb. 2: 187. 1930; 237. G. speciosa Mart. Hist. Nat. Palm. 2: 81, pls. 66, 67. 1823. G. microcarpa Huber, Bol. Mus. Goeldi 4: 476. 1904; 239, essentially a nomen nudum.

Trunks usually cespitose, 20 (-30) meters tall, lightly annulate, long $(3 \mathrm{~cm}$.) aculeate, with a coma of incurved crisped leaves about 2 meters long; segments approximate, many, linear-lanceolate, longacuminate, about $6 \mathrm{dm}$. long, $3 \mathrm{~cm}$. wide, midnerve prominent above, the 3 or 4 secondaries both sides, margins remotely setulose or minutely aculeate; upper spathe sparsely brownish aculeate; spadix early yellowish tomentose (peduncle aculeate), branches 2-3 dm. long; male flowers crowded, 5-6 mm. long, calyx $1.5 \mathrm{~mm}$. long, subpatelliform, corolla as subconnate disk fleshy, turbinate globose; female flowers $7-8 \mathrm{~mm}$. long, calyx $1 \mathrm{~mm}$. long; fruit mostly $4 \mathrm{~cm}$. long, $3 \mathrm{~cm}$. in diameter, applanate from base or concave-ovoid or 
globose-rounded, glabrous, as many as 70 or 80 to a spadix, the putamen (often aborted) central, acutely turbinate from base, $2 \mathrm{~cm}$. long, half as thick.

Burret (1.c. 237-239) gave a résumé of the evidence relating to the probable origin of the species and suggested that $G$. microcarpa Huber (l.c.), fruit scarcely $1.5 \mathrm{~cm}$. thick, may be the native state; this seems to be borne out by Spruce (Journ. Linn. Soc. 11: 81. 1871), who, observing that even in the Andes the large-fruited examples are around habitations, expressed the opinion that a native small-fruited form might still be found; he noted a small seedless variety (Wallace, l.c., found the seed usually aborted). Further, Spruce gave a practical description: the clustered stems grow to 30 meters high and are thickly armed with long prickles; the numerous curling and drooping leaves rarely exceed 2 meters and have 50-60 leaflets on each side, aggregate by threes and fours and pointing in all directions; the fruits are massed into large pendulous corymbs; and if from their size and vivid colors of yellow and red they may be likened to a wellripened peach (hence the name Peach Palm) in shape they more resemble a hen's egg, although usually rather more conical(!); the thick firm flesh is mealy when cooked, something between chestnut and potato in flavor and superior to either. Tessmann, as recorded by Burret, 237, described the popular "masato" of Loreto, made as "chiche" or, less conventionally, by the use of sugar; after four or five days of fermentation, the drink was "very potent." Illustrated, HBK. l.c. 7, pl. 700; Wallace, Palm. pl. 3; Contr. U. S. Nat. Herb. 16: opposite 308, pls. 55, 56; Weberbauer, 148, pl. $2 A$.

Loreto: Pampa de Sacramento, (Huber, type, G. microcarpa). Yarina-cocha, middle Ucayali (Tessmann, perhaps, fide Burret). Typical state apparently only in cultivation. "Pijuanyo," "pifuayo" or "sara-pifuayo" (Tessmann), "pisho-guayo" (bird fruit, Quechua), "chonta ruru," "chonta dura."

Bactris hirta Mart. Hist. Nat. Palm. 2: 104, pls. 60, 74, figs. 1-3. 1826; 184. B. mollis Damm. Verh. Bot. Ver. Brandenb. 48: 129. 1907, fide Burret.

Stems a meter or two high, a half $\mathrm{cm}$. or so thick, not at all spiny but fuscous tomentose above and the petioles $(5 \mathrm{~cm}$. long) as leaf rachis densely but softly black-setose; leaves cuneate-obovate, shortly bifid, more or less lanuginose beneath, pilose above, lobes triangular, scarcely acute, nerves about 12 , width below sinus 9-13 cm., length $2.5 \mathrm{dm}$.; spadix infrafoliar, bifid, erect-spreading in fruit, $5-10 \mathrm{~cm}$. 
long, outer spathe reddish-tomentose, inner coriaceous, fuscous-glabrous; peduncle compressed, setose, 2-4 dm., the 2 branches half as long, male flowers approximate above; female corolla setulose, $2.5 \mathrm{~mm}$. long, long-exceeding the calyx; fruit olive-black, acutely cusped, $1 \mathrm{~cm}$. long, $8 \mathrm{~mm}$. in diameter, sparsely setulose.-Leaves of $B$. mollis as to type a little deeper parted, the fruit somewhat smaller, differences not specific (Burret). F.M. Neg. 18614.

Loreto: Leticia, Ule 6221 (type, B. mollis). Adjacent Colombia; Brazil.

\section{Bactris Killipii Burret, Repert. Sp. Nov. 34: 175. 1933.}

Type (about 2 meters tall) smooth but the sheaths $(12 \mathrm{~cm}$. long) and inner spathes fuscous furfuraceous, the peduncles early arachnoid tomentose, larger than the spike ( $4 \mathrm{~cm}$. long); petioles $3 \mathrm{dm}$. long, at first fuscous leprose; leaves simple, deeply bifurcate, glabrous, $4.6 \mathrm{dm}$. long, each lobe with 9 direct primary nerves; lobes to $3.5 \mathrm{~cm}$. wide at base, strongly dilated above, rather abruptly contracted and narrowed in the upper third, the inner margin straight, $4 \mathrm{dm}$. long; spadix simple, $12 \mathrm{~cm}$. long; dilated part of spathe about $6.5 \mathrm{~cm}$. long, acute, slightly produced; glomerules 3 -flowered, dense, not alveolate, male flowers solitary toward apex; female calyx tubular, 3-dentate as included corolla, pistil glabrous, staminodal tube none.-Resembles B. Luetzelbergii Burret, 174, and B. Huberiana Burret, l.c., in the directly disposed nerves and inner margins but the lobes are much wider and strongly dilated; in the latter the rachis is $12 \mathrm{~cm}$. long, lobes 26, $2 \mathrm{~cm}$. long, and as it is known from adjacent Colombia and Brazil it may be found in Peru.

Loreto: Iquitos, (Killip \& Smith 27305, type).

Bactris Lakoi Burret, Repert. Sp. Nov. 34: 187. 1934.

Slender, more or less setose-hirsute, the stems nearly $7 \mathrm{~mm}$. thick with about 10 oblong pinnate leaves $6.5 \mathrm{dm}$. long or longer (petioles to $2.5 \mathrm{dm}$. long or longer); spathes as petioles densely black-setose, the slender setae whitish at the tumid base; segments hirsute both sides, 20-25, mostly aggregate, narrowly linear, falcate toward the acuminate apex, the larger intermediate to $1.5 \mathrm{dm}$. long, about $12 \mathrm{~mm}$. wide, the apical shorter, wider, all on nerves and veins both sides rather long-setulose, flexibly hirsute and margins ciliate; upper spathe $6.5 \mathrm{~cm}$. long, densely black-setose; spadix branches $2(-3)$, in fruit recurved, 5-6 cm. long, peduncles densely setose, shorter; 
branches about $3 \mathrm{~cm}$. long, the 3-flowered glomerules regularly disposed (type), laxly spiralled; fruiting perianth with broadly 3-lobate calyx, the fuscous setulose corolla many times longer, staminodal cup none; fruit mammillate, striate and transversely lineo'ate.The Hopp specimen has 3 spadix branches; one, also near the base, is mostly male, the others have male flowers scattered between the usual 3-glomerate ones; allied to $B$. hylophila Spruce, and relations (more northern), but the foliage is much smaller, more delicate (author).

San Martín: (Hopp 1114). Río Putumayo on the Brazil boundary, (Carl Lako 1, type). Brazil.

Bactris mitis Mart. Hist. Nat. Palm. 2: 102. 1823; 185. B. cuspidata Mart. var. mitis Drude in Mart. Fl. Bras. 3, pt. 2: 329. 1881 in part, fide Burret.

Resembles B. cuspidata Mart. but leaves interruptedly pinnate, (3) 6-10 pairs, oblong-oblanceolate, about $2 \mathrm{dm}$. long, 1.5-4 cm. wide, the lower 2-nerved, the medial 1-nerved, the broader apical 2-3-nerved, all glabrous or margins setose-ciliate; spadix branches 2-3, spathes appressed fuscous setose.-Type from the Rio Japurá but similar species, probably variants, have been recorded from the Rios Purus and Jauary. F.M. Neg. 18623.

Peru (probably). Adjacent Brazil.

Bactris naevia Poepp. ex Burret, Repert. Sp. Nov. 34: 179. 1933.

Stems arundinaceous, about $8 \mathrm{~mm}$. thick, the upper internodes 4.5-5 $\mathrm{cm}$. long, smooth except the leaf-lobes toward apex blacksetulose, otherwise glabrous or early furfuraceous as the sheaths, these ovate below the petiole, the latter (seen) $16.5 \mathrm{~cm}$. long, the leaf-rachis $1.5 \mathrm{dm}$. long and the upper spathe (free part) $6.5 \mathrm{~cm}$. long; leaves nearly obovate, rather shortly contracted, scarcely to the middle bifurcate, about $27 \mathrm{~cm}$. long, $16.5 \mathrm{~cm}$. wide, primary nerves 10 , lobes short, subovate, abruptly acuminate, $14 \mathrm{~cm}$. long; spadix simple, to $7.5 \mathrm{~cm}$. long, broken sheath $4.5 \mathrm{~cm}$. long, spike glabrous, $3 \mathrm{~cm}$. long, the glomerules 3 -flowered to apex, spiralled, lightly alveolate; perianth in fruit glabrous, calyx 3 -lobed as corolla, subequal, nearly $5 \mathrm{~mm}$. across; staminodal cup none; fruit small (pea size), glabrous, globose, 6-7 mm. in diameter.-Confused with $B$. simplicifrons Mart., 176, of the lower Amazon, typically at least with deeply parted leaves, the lobes sigmoid. B. brevifolia Spruce, 178 , the known range more northern, has rachis $1 \mathrm{dm}$. long, leaf lobes 
(as to original) about $18 \mathrm{~cm}$. long and $8 \mathrm{~cm}$. wide (author); of course the stability of these observed differences and thus their genetic significance are as yet unknown. Trail, Journ. Bot. 15 (6): 1. 1877, treated the Spruce plant as a variety of that of Martius, in which Drude, l.c. 321, included it. F.M. Neg. 31315.

Loreto: Drier woods, Yurimaguas, (Poeppig 2475, type, Herb. Munich; at Vienna, Poeppig 2476). Brazil (Rio Madeira).

Bactris riparia Mart. Hist. Nat. Palm. 2: 97, pl. 71, fig. 4. 1823; 220; 353 (Drude).

Crowded, stoloniferous, spiny at the nodes, a few to 15 meters tall, 5-10 cm. in diameter, the spines black, 1-7 cm. long; leaves 1.5-2 meters long, the 40-50 segments 3-5-aggregate, linear-acuminate, the apex bidentate, the upper part 4-5 dm. long, $2 \mathrm{~cm}$. wide, glabrous above, the shorter lower part minutely pilose or setulose, the petioles and leaf-rachis sparsely aculeate; spadix 3-4 dm. long, peduncle minutely aculeate, elongate, the shorter $(1 \mathrm{dm}$. long) rachis with 20-30 branches; upper spathe fusiform, long-acuminate, setiform-aculeate especially toward tip, the scarcely pungent setae spreading, black; male flowers ochroleucous, calyx minute, corolla 3-4 times longer, female flowers rarely scattered on the middle of the branches, calyx $1 \mathrm{~mm}$. long, corolla cylindric, many times longer, white tomentose and appressed setulose; fruit spheroid, acutely cusped, glabrous, $1.5-2 \mathrm{~cm}$. in diameter.-The similar $B$. longifrons Mart. (1.c. 106), of the lower Amazon, listed from Peru by Dahlgren, is probably a lapsus; spathe tomentose between the brown spines, these $2.5 \mathrm{~cm}$. long, terete. F.M. Neg. 18628 (B. longipes, 18618).

Peru (perhaps). Adjacent Brazil.

Bactris trichospatha Trail, Journ. Bot. 15: 41. 1877; 204; 339 (Drude).

Stems clustered, rhizomatous, rarely 3 meters tall, $1.5-2.5 \mathrm{~cm}$. thick, usually aculeate as the sheath, petioles (1-5 cm. long) and ordinarily leaf rachis; leaves 1.5-2.5 meters long, segments many, one variety $4-6$, broadly lanceolate, falcate, long-acuminate, mostly 1.5-2.5 dm. long, 3-5 cm. wide, reduced toward apex, secondary nerves 5-7 (9-12), glabrous above, velutinous beneath, all except apical, free; spadix erect, 2-3 dm. long or longer, upper spathe ligneous, reddish tomentose, branches $6-10$, fastigiate; male flowers white, $5 \mathrm{~mm}$. long, calyx segments subulate, petals ovate, female 
setose, usually twice longer than calyx, few toward the apex of the branches; fruit dark violet, subglobose, setose, $1.5 \mathrm{~cm}$. in diameter. - Peduncle and inner spathe covered with short brown bristles resembling velvet (Trail). Trail lists Tabatinga at the boundary with Peru as one of several localities. B. longisecta Burret (1.c. 205), related, has linear-lanceolate segments $5.5-6 \mathrm{dm}$. long, $4.5 \mathrm{~cm}$. wide, the upper much smaller. F.M. Neg. 18635.

Loreto (undoubtedly). Adjacent Brazil.

\section{DESMONCUS Mart.}

Reference: Burret, Repert. Sp. Nov. 36: 197-221. 1934.

Supported by the modified spine-like segments of the whip-like rachis end of the pinnate leaves or scandent, the stem in time much elongated, remaining slender, the leaf-rachis with straight or more or less aculeate (Peru), mostly (or entirely) recurved prickles. Upper spathe often recurved-aculeate from a conico-lageniform base (Peru). Stamens 6 or sometimes 9.-Otherwise like Bactris, and as various in floral characters. Name conserved.

Rachis scarcely filiform, the branches probably many.

Leaf-segments long-acuminate both ends.......... D. prunifer.

Leaf-segments acute at base .............. longifolius. Rachis subfiliform as the few (if any) branches.

Spadix branches $3-4 \ldots \ldots \ldots \ldots \ldots \ldots$. leptospadix.

Spadix perhaps simple....................... D. vacivus.

Desmoncus leptospadix Mart. Palm. Orbign. 10: 52. 1847; 216; 308 (Drude). Atitara leptospadix (Mart.) Ktze. Rev. Gen. 727. 1891. D. leptoclonos Drude ex Damm. Verh. Bot. Ver. Brandenb. 48: 129. 1907, fide Burret.

Stem diameter $5 \mathrm{~mm}$.; sheath elongate, membranous, smooth or shortly setose-aculeate; leaves about 1 meter long, rachis shortly and sparsely aculeate, segments exactly opposite, foliose 3-4 pairs, the larger lanceolate or elliptic, acuminate, $17 \mathrm{~cm}$. long, $4 \mathrm{~cm}$. wide, the narrower $2 \mathrm{dm}$. long, $2.5 \mathrm{~cm}$. wide, lacking toward base, toward apex spiniform (3-4 pairs), trigonous-conical, the lower $1.5-2.5 \mathrm{~cm}$. long, spreading or separated; spathe not aculeate as spadix, the latter 2-3 dm. long, long-included, the rachis filiform, the 3-4 very slender branches lax, 4-10 cm. long; fruit oblong-ellipsoid, acute both ends; 
putamen about $8 \mathrm{~mm}$. long, $5 \mathrm{~mm}$. in diameter.-D. mitis Mart. Hist. Nat. Palm. 90. 1823; 217; 308 (Drude) has 15-18 pairs of lanceolate pinnae (6-8 pairs subulate, lanceolate); D. setosus Mart. l.c., 315 (Drude) 9-11 pairs (4-5 subulate), linear leaf segments only 1.5-2 $\mathrm{dm}$. long, $1.5 \mathrm{~cm}$. wide; both have been recorded at more than one station not far from eastern Peru. Liana 2.5 meters tall, $5 \mathrm{~mm}$. thick (Tessmann).

Loreto: Yurimaguas, (Poeppig, type). Soledad, lower Río Itaya, (Tessmann 5236). Amazonian Brazil.

Desmoncus longifolius Mart. Palm. Orbign. 10: 52. 1847; 211.

Sheath $4 \mathrm{dm}$. long or longer, rather densely aculeate as leaf-rachis to tip with straight subulate prickles and shorter hamate ones, $2-8 \mathrm{~mm}$. long; leaf-segments 7-8 pairs, lanceolate, long-acuminate both ends, $3 \mathrm{dm}$. long, 2.5-4 cm. wide, 2-3 pairs subulate, hamate, straight, strongly enlarged at nodose base, 3.5-4 cm. long.-Burret (1.c.) has added the following information from Weberbauer specimen (spathe lacking) : upper part of peduncle aculeate with small straight prickles, black above; rachis $16 \mathrm{~cm}$. long, branches about 20, scattered, basal bract obvious, oblong, subacuminate; flowers mostly 3-glomerulate; perianth (fruiting) cupulate, nearly $3 \mathrm{~mm}$. high, calyx low, minutely 3-denticulate, corolla more than twice as high; fruit ellipsoid, overall $19 \mathrm{~mm}$. long, $14 \mathrm{~mm}$. in diameter, rather rugose, sublustrous, apex not at all mammillate, base shortly contracted, pulp yellow, sweet.

Huánuco: Pozuzo, (Ruiz \& Pavón, type, Herb. Webb).—Junín: Open wood near La Merced, (Weberbauer 1906). "Cachapurina."

Desmoncus prunifer Poepp. ex Mart. Hist. Nat. Palm. 2: 148. 1837; 216. Atitara prunifer (Poepp.) Ktze. Rev. Gen. 727. 1891.

Sheath, petiole, inner spathe and peduncle black-setose and aculeate, spines conical, straight or especially on the leaf-rachis hamate, very dense on the lower spathe; leaf-segments 10-15 pairs, oblong, acute at base, long-acuminate, the $4-5$ spiniform pairs subulate; fruit oval, $2.5 \mathrm{~cm}$. long.-Ascends to 10 meters; leaves (with excurrent rachis) $14 \mathrm{dm}$. long; spadices subaxillary, solitary, branched, longer than $4 \mathrm{dm}$., the peduncle nearly $2 \mathrm{dm}$. long; drupe orange, succulent, acid-sweet; albumen edible (Martius). - Unfortunately, no other data. F.M. Neg. 31323.

Loreto: Yurimaguas, (Poeppig, type). 
Desmoncus vacivus Bailey, Gentes Herb. 8: 186. 1949.

Weak, scandent, only minutely aculeate; sheaths apically reticulate; leaves about 5 pairs, opposite or nearly, lanceolate-elliptic, acuminate, $10-12 \mathrm{~cm}$. long, 2-3.5 $\mathrm{cm}$. wide, lateral nerves prominent; petioles and rachis sparsely aculeate with hamate prickles 1-2 $\mathrm{mm}$. long; terminal spiniform leaflets about 4 pairs, to $2 \mathrm{~cm}$. long, very slender, reflexed; spadix perhaps simple; fruit ellipsoid, $2-2.5 \mathrm{~cm}$. long, $2 \mathrm{~cm}$. thick, minutely cusped, smooth; seed strongly reticulate.-No comparison made by author; it will doubtless be found, whatever its correct name, in adjacent Peru, as type, $R$. E. Schultes 3941, is from Río Igaraparaná near the boundary.

Loreto (no doubt). Colombia.

It may be appropriate to cite here, in connection with the generic problems referred to above, the work of P. B. Tomlinson. Tomlinson's summary of systematic anatomy of the palms will appear in the forthcoming series, edited by C. R. Metcalfe, Anatomy of the Monocotyledons, published by the Clarendon Press, Oxford. 




$$
30112049897538
$$

